\title{
Retrieval/Ex Situ Thermal Treatment Scoring Interaction Report
}

\author{
Brian D. Raivo \\ John G. Richardson \\ Published November 1993 \\ Idaho National Engineering Laboratory \\ EG\&G Idaho, Inc. \\ Idaho Falls, Idaho 83415
}

Prepared for the

U.S. Department of Energy

Office of Environmental Restoration and Waste Management

Under DOE Idaho Operations Office

Contract DE-AC07-76ID01570 


\section{Retrieval/Ex Situ Thermal Treatment Scoring Interaction Report}

EGG-WTD-10719

Revision 0

Prepared by

J. G. Richardson, Engineer

Date

Environmental Restoration Technology Development

Reviewed by

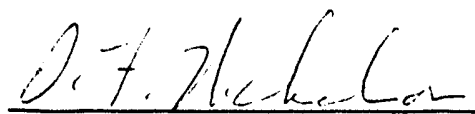

D. F. Nickelson, S\&E Project Manager

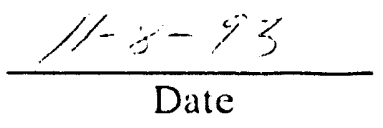

Environmental Restoration Technology Development

Approved by

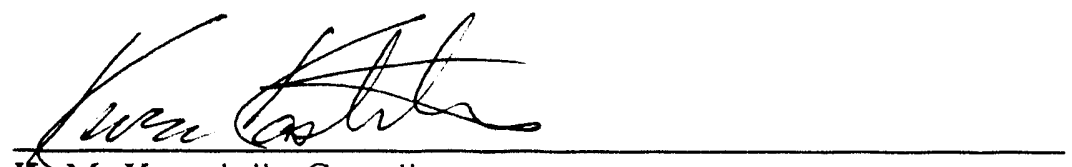

K.M. Kostelnik, Coordinator

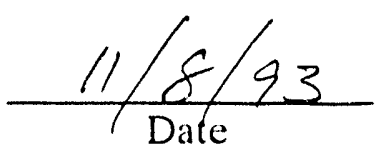

Buried Waste Integrated Demonstration 


\begin{abstract}
A retrieval/ex situ thermal treatment technology process option lor the Idaho National Engineering Laboratory transuranic waste pits and trenches is presented. A system performance score is calculated, and assumptions, requirements, and refirence baseline technologies for all subelements are included.
\end{abstract}




\section{SUMMARY}

This report presents a retrieval/ex situ thermal treatment technology reference baseline for scoring new or developmental technologies for the Buried Waste Integrated Demonstration (BWID) Program. It consists of a scoring matrix and baseline suite of technologies for a system design concept for the Radioactive Waste Management Complex transuranic pits and trenches, and derives a system scoring matrix from that concept.

The configuration option used as the basis for this report is a retrieval/ex situ thermal treatment system with interim storage following retrieval and a metal presort before treatment. The retrieval technology uses remote excavator with an enclosed conveyor transport. The treatment technology uses desorption/incineration followed by arc melting. This process option was presented in an earlier report and has been populated in this report by commercial off-the-shelf or construct-tospecification hardware.

The configuration option consists of 40 functional subelements and represents a cradle-tograve description of the remediation system. A block diagram of the option is presented, and each subelement is described in four sections: Technical Background and Assumptions, Requirements, Process Functional Description, and Reference Baseline Technology.

Twenty-three system performance measures are presented. These are based on the BWID Performance-Based Technology Selection Filter (PBTSF) scoring methodology and represent performance metrics that have been developed to evaluate systems and technologies. Finally, a system performance score is calculated based on PBTSF scoring formulas. 


\section{CONTENTS}

ABSTRACT $\ldots \ldots \ldots \ldots \ldots \ldots \ldots \ldots \ldots \ldots \ldots \ldots \ldots \ldots \ldots \ldots \ldots \ldots \ldots$

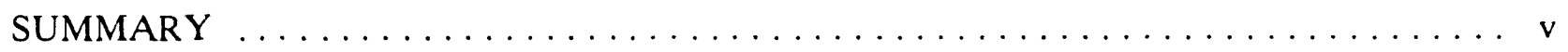

ACRONYMS $\ldots \ldots \ldots \ldots \ldots \ldots \ldots \ldots \ldots \ldots \ldots \ldots \ldots \ldots \ldots \ldots \ldots \ldots \ldots$

1. INTRODUCTION $\ldots \ldots \ldots \ldots \ldots \ldots \ldots \ldots \ldots \ldots \ldots \ldots \ldots \ldots \ldots$

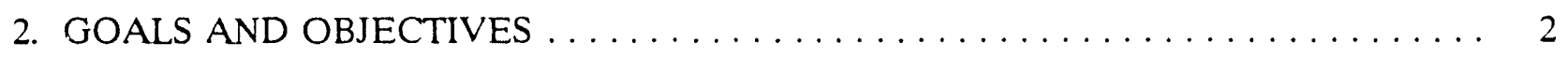

3. WASTE AREA GROUP AND OPERABLE UNIT DESCRIPTION $\ldots \ldots \ldots \ldots$

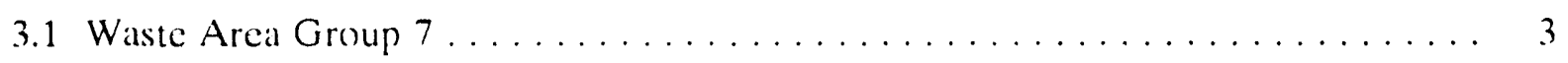

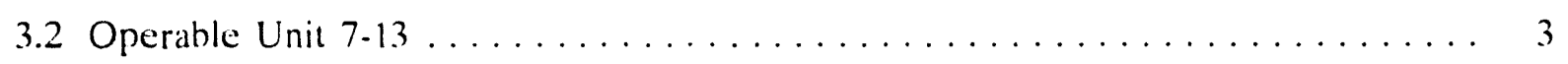

4. REMEDIATION SYSTEM DESCRIPTION $\ldots \ldots \ldots \ldots \ldots \ldots \ldots \ldots \ldots$

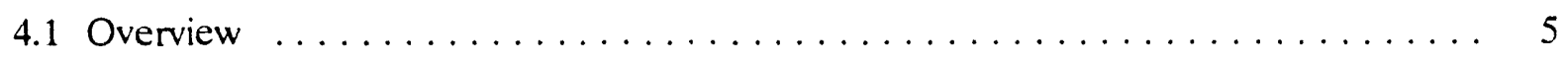

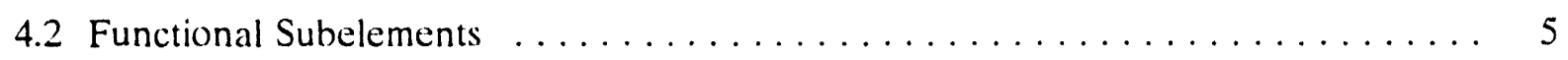

4.2.1 Functional Subelement 1.0 Site/Waste Characterization . . . . . . . 5

4.2.2 Functional Subelement 2.0 Belowgrade Isolation . . . . . . . . . . 9

4.2.3 Functional Subelement 3.1) Abovegrade Containment . . . . . . . . 10

4.2.4 Functional Subelement 4.1) Overburden Characterization . . . . . . . . 11

4.2.5 Functional Subelement 5.1) Overburden Removal . . . . . . . . . . . 11

4.2.6 Functional Subelement 6.1) Storage of Contaminated Overburden . . . . 12

4.2.7 Functional Subelement 7.0 Noncontaminated Overburden Storage . . . . . 12

4.2.8 Functional Subelement 8.0 Retrieval .................. 12

4.2.9 Functional Subelement 9.0 Waste Conveyance . . . . . . . . . . . 14

4.2.10 Functional Subelement 10.() Size Reduce . . . . . . . . . . . . . 14

4.2 .11 Functional Subelement 11.0) Radioactive and VOC Assay . . . . . . . . 15

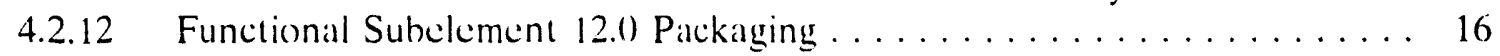

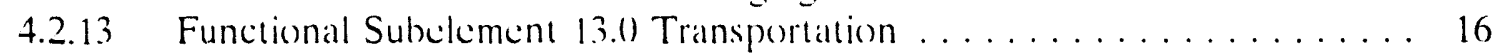

4.2.14 Functional Subelement 14.0) INEL Interim Storage . . . . . . . . . 17

4.2.15 Functional Subelement 15.0) Transportation to Treatment . . . . . . . 17

4.2.16 Functional Subelement 16.0) Treatment Facility General Requirements . . 17

4.2.17 Functional Subelement 17.0) Treatment Facility Receiving . . . . . . . . 19

4.2.18 Functional Subelement 18.0 Treatment Waste Conveyance ......... 19

4.2.19 Functional Subelement 19.0 Size Reduction . . . . . . . . . . . 21

4.2.20 Functional Subelement 20.0) Pretreatment Characterization . . . . . . . 21

4.2.21 Functional Subelement 21.0 Metals Sort ............... 22

4.2.22 Functional Subelement 22.() Thermal Desorber ............. 22

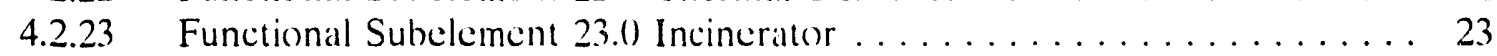

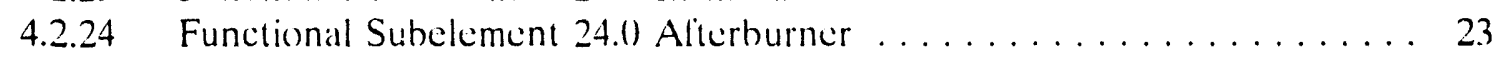

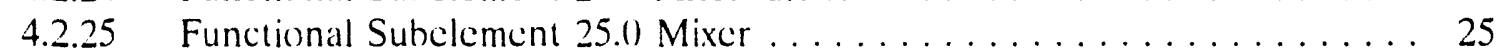


4.2.26 Functional Subelement 26.1) Oxidizing Slag, Oxidizing Metal/Metal Tapping Melter . . . . . . . . . . . . . . . . . . . 25

4.2.27 Functional Subelement 27.1) Homogeneous Slag Frit/Monolith . . . . . . 26

4.2.28 Functional Subelement 28.0 Tapped Metal . . . . . . . . . . . . . 27

4.2.29 Functional Subelement 29.0 Oflgas Treatment ......... . . . . . 27

$4.2 .30 \quad$ Functional Subelement 30.0 Mixer . . . . . . . . . . . . . . 28

4.2.31 Functional Subelement 31.0 Otfgas Residuc Melter . . . . . . . . . . 29

4.2.32 Functional Subelement 32.0 Offgas Frit/Monolith . . . . . . . . . . . . 29

4.2.33 Functional Subelement 33.0 Post-Treatment Radioactive Assay . . . . . . 30

4.2.34 Functional Subelement 34.0 Post-Treatment Medium Temperature

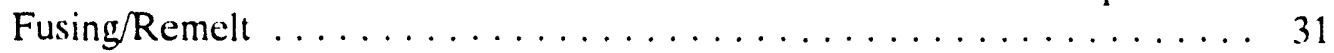

4.2.35 Functional Subelement 35.0 Heat Treal/Controlled Cool . . . . . . . . . 31

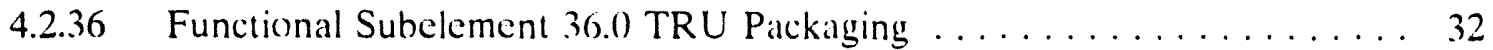

4.2.37 Functional Subelement 37.0) Final Package Assay . . . . . . . . . . . 32

4.2.38 Functional Subelement 38.() INEL TRU Interim Storage . . . . . . . . . . 33

4.2.39 Functional Subclement 39.1) Reclassilicd LLW Packaging . . . . . . . . . 33

4.2.4() Functional Subelement 4).() LLW Packaging INEL Disposal . . . . . . . 34

5. SYSTEM PERFORMANCE MEASURES $\ldots \ldots \ldots \ldots \ldots \ldots \ldots \ldots \ldots$

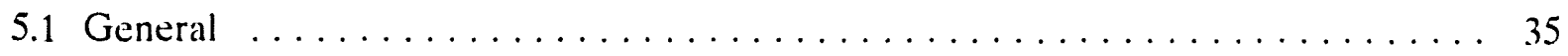

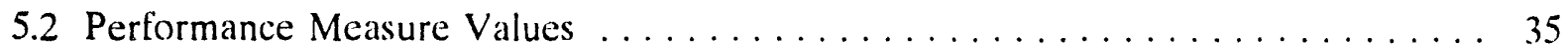

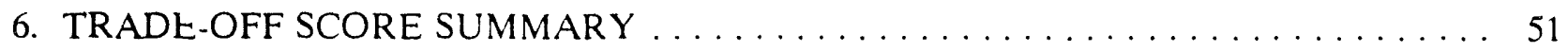

7. REFERENCES $\ldots \ldots \ldots \ldots \ldots \ldots \ldots \ldots \ldots \ldots \ldots \ldots \ldots \ldots \ldots$

Appendix A-INEL OU 7-1.3 Waste Pit and Trench Characteristics Tables $\ldots \ldots \ldots$ A-1

\section{FIGURES}

1. Map of the SDA and RWMC at the INEL $\ldots \ldots \ldots \ldots \ldots \ldots \ldots \ldots$

2. Retrieval/interim storage/metals sort/thermal treatment option $\ldots \ldots \ldots \ldots \ldots$

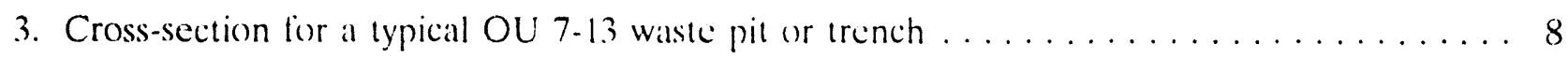




\section{ACRONYMS}

\begin{tabular}{|c|c|}
\hline BSG & Borosilicate glass \\
\hline BWID & Buried Waste Integrated Demonstration \\
\hline CAM & Continuous air monitor \\
\hline COTS & Commercial off-the-shelf \\
\hline DOE & U. S. Department of Energy \\
\hline FTE & Full time equivalent \\
\hline HLW & High-level wastc \\
\hline HPM & High vapor pressure metal \\
\hline INEL & Idaho National Engineering Laboratory \\
\hline LLW & Low-level waste \\
\hline NESHAPS & National Emission Standards for Hazardous Air Pollutants \\
\hline OU & Operable unit \\
\hline OSHA & Occupational Safety and Health Administration \\
\hline PAN & Passive active ncutron \\
\hline PBTSF & Performance-based technology selection lilter \\
\hline RWMC & Radioactive Waste Management Complex \\
\hline $\mathrm{SDA}$ & Subsurlace Disposal Area \\
\hline SWEPP & Stored Waste Isolation Pilot Plant \\
\hline TDF & Technology Design File \\
\hline TRU & Transuranic \\
\hline TSA & Transuranic Storage Area \\
\hline $\mathrm{UBC}$ & Uniform Building Code \\
\hline VOC & Volatile organic compound \\
\hline WAC & Waste Acceptance Criteria \\
\hline
\end{tabular}




\section{Retrieval/Ex Situ Thermal Treatment Scoring Interaction Report}

\section{INTRODUCTION}

The mission of the Buried Waste Integrated Demonstration (BWID) systems analysis study is to identify and evaluate systems for remediation of transuranic (TRU)-contaminated waste pits and trenches located within the Subsurface Disposal Area (SDA) of the Idaho National Engineering Laboratory (INEL). One objective of the study has been to develop a performance-based technology selection filter (PBTSF) and scoring matrix to evaluate candidate systems and their enabling technologies. This report presents a scoring matrix and bascline suite of technologies for a retrieval and thermal ex situ waste treatment design concept for the Radioactive Waste Management Complex (RWMC) TRU pits and trenches and derives a system scoring matrix from that concept. The purpose for generating the design eoncept and system scoring matrix is to provide a lechnology reference baseline for scoring new or developmental lechnologies.

The configuration option used as the basis lor this report is a retrieval/ex situ thermal treatment concept with interim storage following retrieval and a metal presort betore treatment. The retrieval technology uses a remote excavator with an enclosed conveyor transport. and the treatment technology uses desorption/incineration followed by arc melting. This process option was presented in an earlier report ${ }^{1}$ as Option E, Retrieval/Interim Storage/Metals Sort/Thermal Treatment, and has been supplemented in this report by commercial ofl-the-shelf (COTS) or construct-to-specification hardware. 


\section{GOALS AND OBJECTIVES}

The BWID PBTSF has been developed to evaluate systems and technologies. The primary objective of this report is to derive and present system level scores for the retrieval/ex situ thermal treatment configuration option in 23 performance areas. This activity also includes selecting or defining reference baseline enabling technologies for 40 lunctional subelements within the configuration option. 


\section{WASTE AREA GROUP AND OPERABLE UNIT DESCRIPTION}

\subsection{Waste Area Group 7}

Waste Area Group 7 encompasses the RWMC, which was established in 1952, and is a controlled area for disposal of solid radioactive wastes gencrated by $U$. S. Department of Energy (DOE) operations at the INEL and other DOE sites. Fourteen operable units (OUs) have been identified at RWMC involving approximately $384,000 \mathrm{yd}^{3}$ of potentially contaminated soil spread over 144 acres. RWMC includes the Transuranic Storage Area (TSA) and SDA. SDA, which is the location of the largest remediation activity at the INEL, is a confirmed release site (see Figure 1). Findings from environmental monitoring activities have determined that migration of TRU radionuclides has occurred to the 110 - $\mathrm{ft}$ sedimentary interbed bencath $\mathrm{RWMC}$. The aquiter is located $600 \mathrm{ft}$ below the surface at this location. In addi $\mathrm{n}$, organic constituents have been detected in the aquifer.

\subsection{Operable Unit 7-13}

OU 7-13 is defined as the pits and trenches containing TRU-contaminated waste at the RWMC SDA. These wastes include TRU, low-level (LLW), and mixed waste in solid and liquid form. Disposal of TRU-contaminated wastes at SDA ceased in 1970. Since then. TRU wastes have been stored aboveground. The exact number of pits and trenches containing TRU will be determined. Soils around or beneath the pits and trenches contaminated by TRU and hazardous wastes are also included in this OU. 


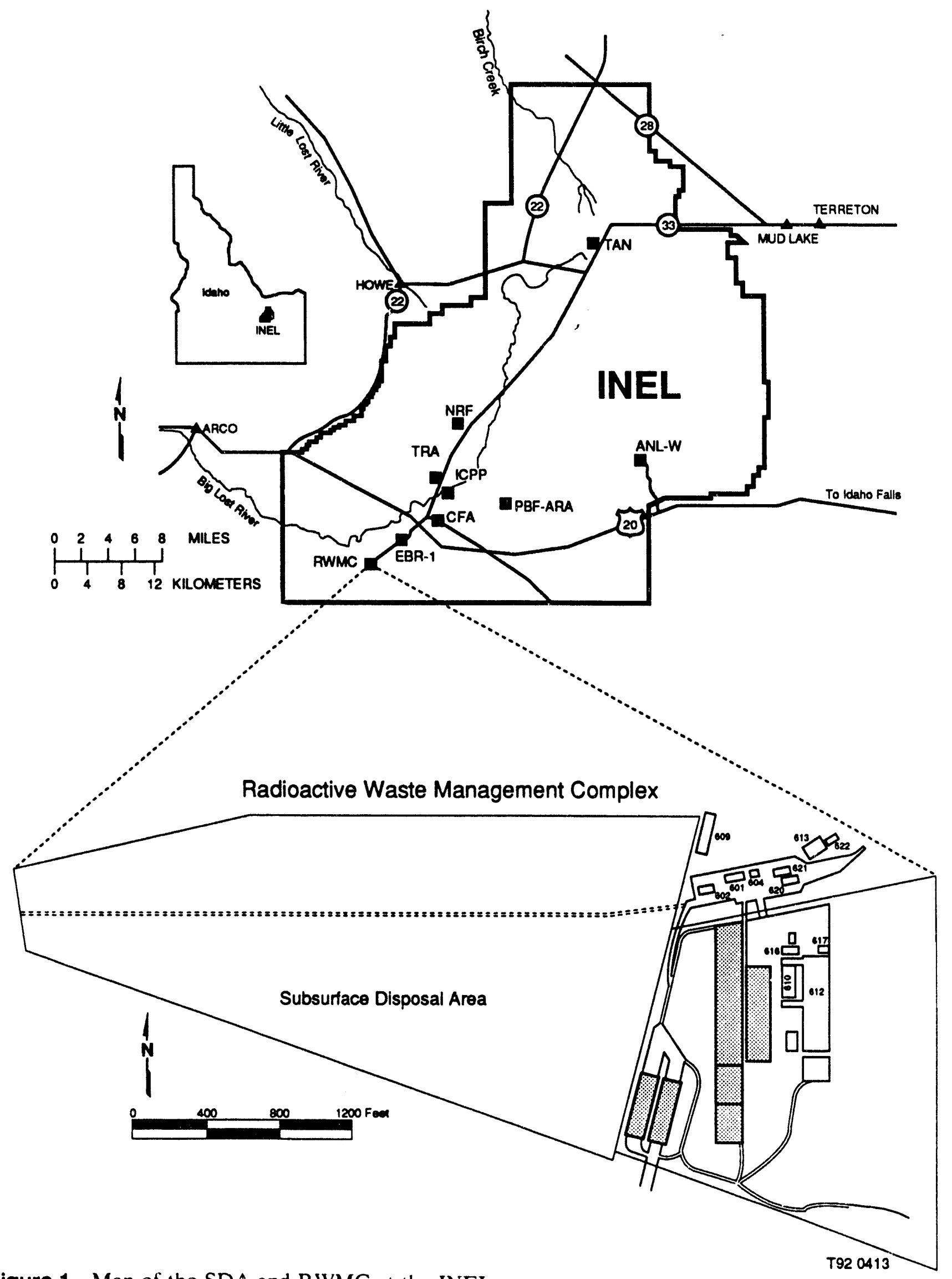

Figure 1. Map of the SDA and RWMC at the INEL. 


\section{REMEDIATION SYSTEM DESCRIPTION}

\subsection{Overview}

Once the pits and trenches are characterized and their contents exhumed, the waste debris/soil is packaged and transported to interim storage. When a treatment facility is operational, the packaged waste will be withdrawn from interim storage and treated. (Current INEL environmental reports ${ }^{a}$ state that wastes exhumed from waste pits and trenches in OU 7-13 will be placed in interim storage untii a suitable treatment facility is operational.) Treatment will involve size reduction and metal sort. The remaining nonmetallic waste streams will be incinerated and recombined with the sorted metals before final high-temperature thermal treatment. Final waste forms will be assayed and designated as LLW or TRU. LLW will be disposed of at the INEL RWMC. TRU waste will be packaged to meet INEL TRU Waste Acceptance Criteria (WAC) and transported to an INEL interim storage tacility until a permanent repessitory for treated buried waste is opened. Appendix $A$ provides the OU 7-13 waste pit and trench characteristics.

\subsection{Functional Subelements}

The configuration option consists of 40 functional subelements. A block diagram of the option is presented in Figure 2. The function of each subelement is described in the following sections.

\subsubsection{Functional Subelement 1.0 Site/Waste Characterization}

4.2.1.1 Background Technical Information and Assumptions. The waste pits were excavated to the underlying basalt layer and backlilled with 2 to 5 lit of soil to provide a level floor. The waste trenches were excavated to the basalt layer, approximalely $10 \mathrm{ft}$ down and averaging $7 \mathrm{ft}$ wide and up to $1800 \mathrm{ft}$ long. ${ }^{2}$ Following excavalion, wastes were placed into the pits and trenches. From 1952 to 1963, the waste containers were stacked to optimize disposal space. During 1963 to 1969, the waste packages were randomly dumped into the pits and trenches to limit worker radiation exposure. In 1969, the waste containers were once again stacked to optimize disposal volume. Once emplaced, the wastes were backfilled and covered with silty clay and sandy soil.

Figure 3 illustrates a cross-section of a typical oU 7-1.3 waste pit or trench and identifies terms used throughout this report. This subelement ensures that no portion of the original pit or trench volume is hypassed during retrieval and minimizes the amount of nonwaste material retrieved.

4.2.1.2 Requirements. The following shall be determined during site/waste characterization:

- Vertical boundaries of the waste pits and trenches

- Depth of the basalt underlying the waste pits and trenches

- Depth of the overburden/waste interlace for cach waste pit and trench

- Location of any outsize waste in the waste seam.

a Unpublished report, "INEL Environmental Restoration Standard Planning Assumptions," May 1992. 


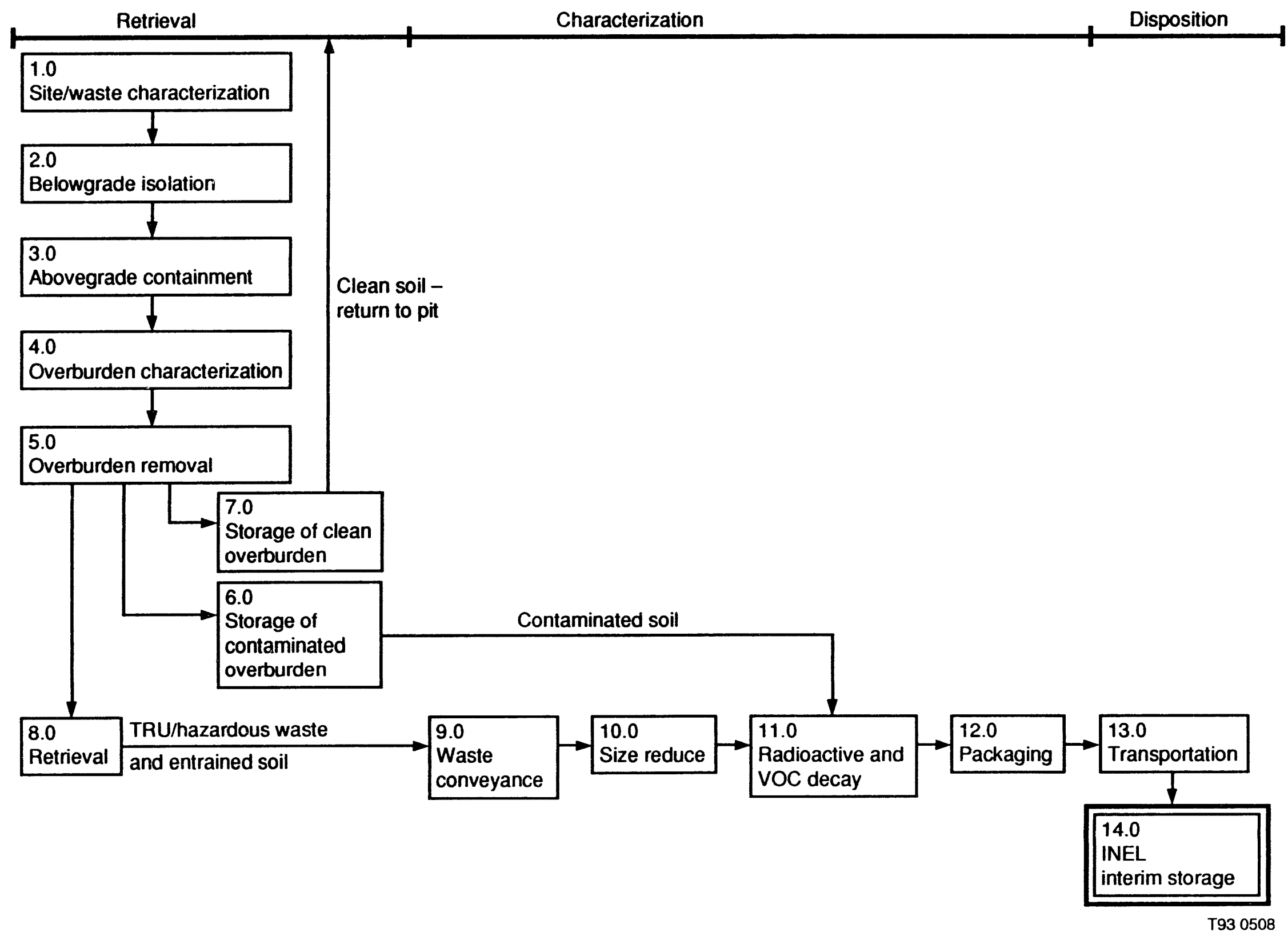

Figure 2. Retrieval/interim storage/metals sort/ thermal treatment option. 


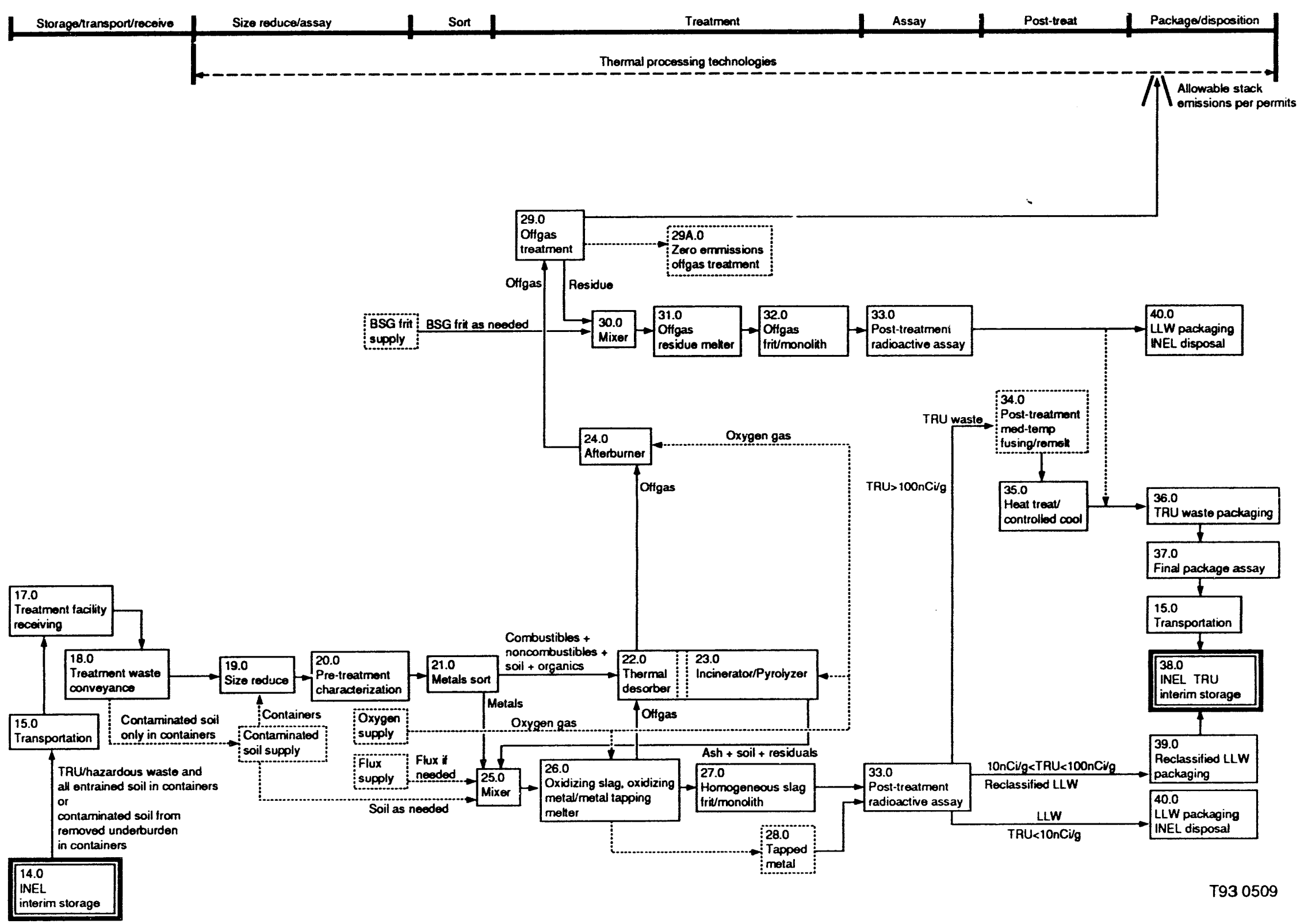

Figure 2. continued. 

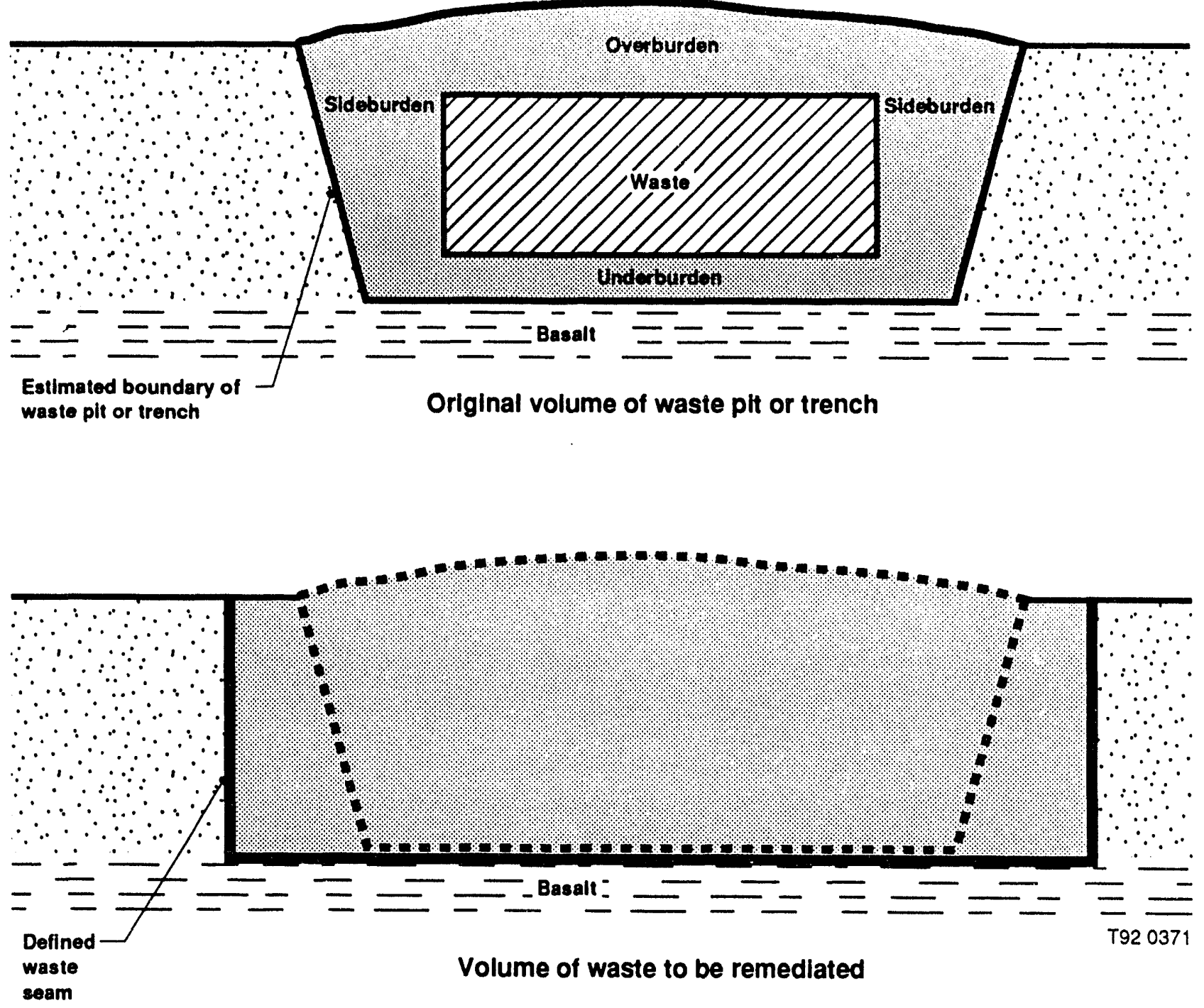

Figure 3. Cross-section of a typical OU 7-13 waste pit or trench. 
4.2.1.3 Process Functional Description. This subelement cannot be represented as a selfcontained, stand alone system. Its purpose is to survey the buried waste site to determine the depth to the basalt, location of the edges of buried stacks of drums and boxes, and il possible, the original excavation boundary. The depth to the basalt and original excavation boundary are the required outputs of this subelement. However, research has shown that locating the original excavation boundary is not feasible. The data from this investigation will be used to establish the surveyed boundaries that will locate the specific volume to be excavaled. The operational aspects of this investigation will involve gathering historical records for the targeted retrieval site, subcontracts to geophysical survey contractors to survey the site with acoustic instrumentation, ground penetrating radar instrumentation, soil conductivity instruments, and boreholes around the buried debris. The contractor, along with INEL investigators, will reduce the, data and summarize the results about the depth to the basalt, edge locations of buried debris, and any indication of the location of the original pit boundaries.

4.2.1.4 Reference Baseline Technology. Commercial waler well drilling will be used to obtain depth to basalt and cuttings samples for analysis of contaminants.

Records will be reviewed to estimale set boundaries and detern ine the variety of contaminants that were disposed.

\subsubsection{Functional Subelement 2.0 Belowgrade Isolation}

4.2.2.1 Background Technical Information and Assumptions. The basalt is assumed to offer belowgrade horizontal isolation of the waste. The subsurface basalt depth is less than 30 ft for any given waste pit or trench.

The concern about leakage through the barricrs is miligated by INEL RWMC site renovations performed under the 30() -year thood drainage program.

The defined waste seam will be established by an institutional review of the estimated boundaries (see Figure 3). Establishment of the delined waste scam will be performed by institutional entities. This group will be expected to identily the defined waste seam boundary for each pit or trench that includes some margin in addition to the estimated boundary values.

The pits and trenches are assumed to be 100 close together to remediate individually. For purposes of evaluation, the pits and trenches will be grouped into seven units. Unit 1 will enclose all pits and trenches between trench 17 on the south. trench 1 on the north (approximately $700 \times 1200 \mathrm{ft}$ ). Unit 2 will enclose pit 3 (approximately $450 \times 150 \mathrm{fi}$ ). Unit 3 will enclose pits 4,6 , $10,11,12,13$, trench 36 , and all pit and trenches in between (approximately $750 \times 150) \mathrm{ft}$ ). Unit 4 will enclose pit 5 (approximately $4(0) \times 6(0)(1)$. Unit 5 will enclose pits 17, 16, and 15 ("L" shaped, approximately $950 \times 60$ it length apart and $550 \times .350$ ft along the base). Unit 6 will enclose trenches 20 and 12 on the south. trenches 41 and 34 on the north, and all trenches in between (approximately $2,500 \times 200 \mathrm{ft}$ ). Unit 7 will enclose Pit 14 (approximately $70 \times 100(0)$ it).

4.2.2.2 Requirements. Engineered barriers shall be constructed extending vertically from the surface to the basalt at the location of the defined waste scam to provide belowgrade isolation of the volume to be remediated. The engineered barriers shall be designed to meet or exceed all the applicable Federal, state, and DOE structural salety standards lor mining or excavations. 
4.2.2.3 Process Functional Description. H-pilings and I-pilings will be used, which are standard COTS items typically used in the mining industry. The pilings are pounded inte the basalt (maximum $30 \mathrm{ft}$ ) and will completely encompass three sides of each unit, which are described in the assumptions (see Section 4.2.2.1). The pilings will be pinned belowgrade as the waste is retrieved.

4.2.2.4 Reference Baseline Technology. The delined waste scam will be established by an institutional review of the estimated boundaries (see Section 4.2.2.1).

The technology used lor belowgrade isolation will be H-pilings and Sheet-pilings.

\subsubsection{Functional Subelement 3.0 Abovęgrade Containment}

4.2.3.1 Background Technical Information and Assumptions. The entire abovegrade containment shall have a facility classitication of moderate hazard in accordance with UCRL-15910. Design and Evaluation Guidelines for Department of Eneris Facilities Subjected to Natural Phenomenon Hazard ${ }^{3}$ and Radioactive Solid Waste Facility in accordance with DOE Order 6430.1A "General Design Criteria". ${ }^{+}$

Replacing structural supports during waste retrieval will require personnel dressed in bubble suits.

4.2.3.2 Requirements. The abovegrade containment structure(s) must encompass the entire volume currently being excavated. The abovegrade containment structure(s) shall be designed and constructed to meet the following applicable INEL building standards: DOE 6430.1 A, UCRL-15910, "DOE-ID Architectural Engineering Standards,."5 Operational Safety Design Criteria Manual, and industry standard Uniform Building Code (UBC).

The abovegrade containment structure(s) shall be designed to

1. Control contamination from beta, gamma, alpha, and hazardous sources to allow maintenance repair or replacement of systems

2. Allow all necessary activities to support ancillary activities conducted within the containment structure such as retrieval. package, and transport of excavated waste

3. Allow ingress/egress of all equipment and personal necessary to pertorm all waste retrieval activitics

4. Allow the egress of retrieved waste packaged lor transport

5. Have temperature and humidity control so that the environment is regulated within the limits required for maintenance repair or replacement activities in a beta, gamma, alpha, and hazardous contaminated environment.

The abovegrade containment structure will hold all operations from overburden retrieval to transport to interim storage/treatment.

4.2.3.3 Process Functional Description. The primary containment is a Herculite sheet (or some other flexible membrane) draped around and lastened to a trame spanning about 150 fl, which contains the retrieval equipment. and is connected to a high efliciency particulate air (HEPA) 
filtering system. The secondary eontainment is a steel frame with stainless stede welded scam walls with an airlock entry large enough to accommodale ingess and egress of the overhurden removal and retrieval equipment. The third eontainment is a sieel frame with painted steel welded seam walls and an airlock entry large enough to accommodate ingress and egress of the overburden removal and retrieval equipment. The secondary and tertiary containment structures will be designed to meet UCRL-15910 and DOE-6430.1A. Section 1.324, building requirements and will encompass each area described in Section 4.2.2.1. The internal structural supports must be designed so that they can be repositioned during the retrieval process because they will originally be placed in the waste seam. The repositioning will occur after a portion of the waste has been retrieved. The new supports will be set into the basalt where waste has been removed.

4.2.3.4 Reference Baseline Technology. The confincment structure is a commercially fabricated structure (size limited to standard commercial fabrication techniques) consisting of three barriers with one way ventilation air thow from areas of least contamination (tertiary) through increasingly contaminated areas (secondary) and exhausted from areass of grealest contamination (primary) through HEPA lilters. The primary barrier is a thexible membrane; the secondary barrier is being a welded stainless steel skin; the certiary is a steel-skinned structure.

\subsubsection{Functional Subelement 4.0 Overburden Characterization}

4.2.4.1 Background Technical Information and Assumptions. Beliore removal of overburden, an extensive characterization of the overburden will be perlormed.

4.2.4.2 Requirements. The characlurization will locate any regions of contamination within the pit or trench overburden. Characterization techniques must be able to sample for radioactive, including TRU, and characteristic and listed hazardous contaminants defined in the BWID systems analysis requirements. ${ }^{7}$

4.2.4.3 Process Functional Description. Grid markings will be made in 4-lit squares of the overburden surtace for removal, and random core sampling within each grid will be performed in diameter cores, 4 in. deep. Each core will then be spread thin and horizontal on a survey pad and scanned for alpha using standard alpha survey instruments. No indications of contamination will allow release of the gridded surtace to a depth of 6 in. and subsequent removal ol the overburden. Postremoval randon sampling of overburden stockpiles shall be performed lor verification of survey results.

4.2.4.4 Reference Baseline Technology. Commorcial tools and instruments grid will be used for marking, shallow core sampling, and standard alpha scanning.

\subsubsection{Functional Subelement 5.0 Overburden Removal}

4.2.5.1 Technical Background and Assumptions. It is assumed that the overburden is not contaminated. The tertiary containment structure will be completed belore any overburden is removed. However, the primary and secondary containment structures are not required during overburden removal.

4.2.5.2 Requirements. Up to $75 \%$ of the estimated overburden depth for each pit or trench will be removed. Sufficient overburden will lelt in place to minimize the possibility of inadvertent contamination exposure. The removal process will separale contaminated (radioactive and hazardous) from noncontaminated overburden. 
Overburden removal operations must control contamination from belat. gamma. alpha, and the hazardous constituents defined in the BWID systems analysis requirements to levels that would allow maintenance to service or repair equipment.

These systems shall meet or exceed all Federal, state, and DOE nuclear standards for explosion proof and fire protection and suppression.

4.2.5.3 Process Functional Description. Overburden removal will be accomplished using commercially available soil stripping equipment. The overburden will be removed in 4 -in. layers until $75 \%$ of the overburden has been removed (as determined by characterization).

4.2.5.4 Reference Baseline Technology. Commercially available soil stripping equipment will be used.

\subsubsection{Functional Subelement 6.0 Storage of Contaminated Overburden}

4.2.6.1 Technical Background and Assumptions. It is assumed th. 'there will be no contaminated overburden. Up to $25^{\circ} \mathrm{c}$ of the uverburden will be handled as contaminated and included in the input waste stream to the melter. This volume is referred to as contaminated in subsequent sections.

4.2.6.2 Requirements. Contaminated overburden must be stored within the abovegrade containment structure(s) and physically separated from retrieved noncontaminated and nonassayed overburden.

Stored contaminated overburden shall not cause a criticality. Stored contaminated overburden shall have beta, gamma, alpha, and hazardous contamination control compatible with containment requirements (see Section 4.2.3.2).

4.2.6.3 Process Functional Description. A weather shickd and LLW box capable of storing $10 \%$ of the total overburden will be used.

4.2.6.4 Reference Baseline Technology. Commercial standard weather shields and waste boxes will be used.

\subsubsection{Functional Subelement 7.0 Noncontaminated Overburden Storage}

4.2.7.1 Technical Background and Assumptions. This volume represents $75 \%$ of the total overburden.

4.2.7.2 Requirements. Retrieved noncontaminaled overburden shall be stored in weather shielded storage. If the noncontaminated storage is located outside the containment building, the noncontaminated overburden shall be surveyed to ensure that it is free of beta, gamma, alpha, and hazardous contamination before removal from the eontainment building.

4.2.7.3 Process Functional Description. Noncontaminated overburden will be stored outside of the secondary containment and inside the tertiary containment. There is no technology for this, just a space.

4.2.7.4 Reference Baseline Technology. Commercial huilding construction will be used. 


\subsubsection{Functional Subelement 8.0 Retrieval}

4.2.8.1 Technical Background and Assumptions. This subelement includes the apparatus to remove all remaining overburden and the waste from the ground.

Multiple gantry apparatus or end effectors will be used because it is not clear that the structures can be disassembled/reassembled or built once the secondary and tertiary containment structures are completed.

4.2.8.2 Requirements. The retrieval system shall comply with the following:

- Exhume material within the waste scam and transler that material to a waste conveyance system

- Operate within the temperature and humidity limits inside the containment structure

- Accommodate operations, maintenance, and repair in a bela, gamma, alpha, and hazardous contamination environment

- Ensure that a criticality cannot ciccur.

Retrieval operations must identily and accommodale alypical waste objects (object. or material incompatible with the retrieval system) or high radiation sources. Identitication may involve characterization at the dig-tace. To accommodate atypical waste objects, the retrieval system may move these objects and stabilize them in the retrieval pit or other designated area to prevent contamination spread and/or to shield high sources of radiation as stated in system requirements. ${ }^{7}$ Retrieval operations may bypass these stabilized objects and continue normal operations until such time that special case equipment and procedures will allow for their removal.

The retrieval system shall meet or exceed all applicable Federal, state, and DOE nuclear standards for explosion prool and lïre protection and suppression.

Retrieval operations and waste packaging for conveyance will be designed so that personnel exposure to radiation will comply with DOE Order 54\$().11 "Radiation Protection for Occupational Workers"8 and personnel exposure to hazardous materials will comply with all applicable Occupational Safety and Health Administration (OSHA) standards.

4.2.8.3 Process Functional Description. Excavalion activities are performed using standard commercially available equipment and procedures. The equipment is operated via an operator in the cab. The cab is modified for salety 10 allow easy access and provide shiclding and isolation. The operator is bubble suited for contamination control. Sets of dual operators working for a given time period per exposure limits are a required lor sility.

4.2.8.4 Reference Baseline Technology. Commercial excavation equipment will be moditied to allow in cab operation by operators wearing bubble suits. Maintenance of equipment will require entry by personnel wearing bubble suits. 


\subsubsection{Functional Subelement 9.0 Waste Conveyance}

4.2.9.1 Technical Background and Assumptions. The conveyance lunctional subelement includes all apparatus to convey the retrieved waste or removed overburden within the containment structure.

4.2.9.2 Requirements. The waste conveyance system shall comply with the following:

- Designed so that a criticality event carnot occur

- Designed to accommodate operations, maintenance, and repair in a beta, gamma, alpha, and hazardous contamination environment

- Meet or exceed all Federal. state, and DOE nuclear sýstems' standards for explosion proof and tire protection and suppression

- Operate within the temperature and humidity limits in the containment structure

- Designed so that personnel exposure to radiation will eomply with DOE Order 5480.11

- Designed so that personnel exposure to hazardous matcrials will comply with all applicable OSHA standards.

4.2.9.3 Process Functional Description. An enclosed conveyance system will be used. including side and cross conveyors, with elevators between the lwo and waste boxes. The conveyors and elevators are standard enclosed equipment. A lunnel is used to direct waste from the excavation equipment into temporary waste boxes on the conveyor.

The waste containers will be heal wrapped with a cellophane like material, swip ed, and surveyed for alpha contamination and decontaminated and surveyed for beta/gamma radiation. The box will then be loaded onto a truck and transported onsite to the size reduction/packaging lacility.

4.2.9.4 Reference Baseline Technology. Commercially labricated, material handling equipment will be used. Maintenance will require entry by personnel wearing bubble suits.

\subsubsection{Functional Subelement 10.0 Size Reduce}

4.2.10.1 Technical Background and Assumptions. The waste in the waste stream will undergo size reduction.

4.2.10.2 Requirements. A size reduction shall occur to the extent necessary so that the waste is in a form compatible with the radiologicalivolatile organic compound (VOC) assay technology. The size reduction system shall comply with the lollowing:

- Designed to accept all waste of the composition and size described in system requirements ${ }^{7}$

- Designed so that a criticality event cannot occur

- Designed to accommodate operations, maintenance, and repair in a beta, gamma, alpha, and hazardous contamination environment 
- Meet or exceed all Federal, state, and DOE nuclear systems'standards for explesion proof and fire protection and suppression

- Operate within the temperature and humidity linits in the containment structure

- Designed so that personnel exposure to radiation will comply with DOE Order 5480.11

- Designed so that personnel exposure to hazardous materials will comply with all applicable OSHA standards.

4.2.10.3 Process Functional Description. Size reduction of items will be to approximately a 6 in. maximum diameler.

4.2.10.4 Reference Baseline Technology. Manual remote sizc reduction of large items will be performed using standard tooling coupled lo remole operated manipulators. Other items will be sized reduced with commercial shredders. Size reduction will be performed remotely within a structurally sound enclosure designed for lïes and small explosions.

\subsubsection{Functional Subelement 11.0 Radioactive and VOC Assay}

4.2.11.1 Technical Background and Assumptions. The INEL TRU WAC ${ }^{10}$ will be used for interim storage and is assumed to cover hazardous. LLW. low-level mixed, TRU mixed waste.

All waste arriving at the assay system can be isolated into near 55-gal drum volumes using standard commercially fabricated equipment lor assay.

4.211.2 Requirements. The radioaclive/VOC assay system shall comply with the following:

- Designed so that a criticality event cannot occur

- Designed to accommodale operations, maintenance, and repalir in a beta, gamma, alpha, and hazardous contamination environment

- Meet or exceed all Federal, state, and DOE nuclear systems' standards loor explosion proof and lire protection and suppression

- Meet requirements of the intorim storige WAC (INEL TRU WAC)

- Operate within the temperature and humidity limits in the eontainment structure

- Designed so that personnel exposure to radiation will comply with DOE Order 5480.11

- Designed so that personnel exposure (o) hazardous malterials will eomply with all applicable OSHA standards

- Capable ol measuring radioactive constituents, includting TRU and organic compounds, identified in the BWID system analysis requirements. ${ }^{7}$ 
4.2.11.3 Process Functional Description. Assilys will he perlormed in balth mode following size reduction. TRU, surlace gamma, and VOC assiay will not necessiarily be concurrent but may be sequential. Assay, system, or subsystem maly be paralleled to meet system throughput.

4.2.11.4 Reference Baseline Technology. Assay equipment will be used that is similar to the Stored Waste Isolation Pilot Plant (SWEPP) passive active ncutron (PAN) for TRU assay in accordance with interim storage WAC. Standard gamma instrumentation for external radiation of containers will be used. Commercial volatile organic sniflers, such as gas chromatographs or mass spectrometers, will be used to detect selected VOCs in accordance with interim storage WAC.

\subsubsection{Functional Subelement 12.0 Packaging}

4.2.12.1 Technical Background and Assumptions. All retrieved waste (including hazardous, LLW and low-level mixed waste) can be packaged and transported to interim storage.

4.2.12.2 Requirements. The retrieved and assilyed waste stream shall be packaged and labeled to meet all of the RWMC transportation requirements." 11.11 and INEL TRU WAC. The packaging system shall comply with the lollowing:

- Designed so that a criticality event ciannot occur

- Designed to accommodate operations, mainlenance, and repair in a beta, gamma, alpha, and hazardous contamination environment

- Meet or exceed all Federal, state, and DOE nuclear systems'standards for explosion proof and tire protection and suppression

- Operate within the temperature and humidity limits in the containment structure

- Designed so that personncl exposure a radiation will comply with DOE Orcier 5480.11

- Designed so that personnel exposure to hazardous malterials will comply with all applicable OSHA standards.

4.2.12.3 Process Functional Description. A connecting conduit will run from the size reduction unit to a double-lid drum passout that will be used to package the size reduced waste into 55-gal drums. Double-lid passout is standard COTS.

4.2.12.4 Reference Baseline Technology. A (touble-lid drum passout will be used to package sized waste into 55 -gal drums.

\subsubsection{Functional Subelement 13.0 Transportation}

4.2.13.1 Technical Background and Assumptions. Transportation to interim storage can occur within the RWMC and, thus, will not have to fully comply with Reference 12.

4.2.13.2 Requirements. RWMC transportation requirements."

4.2.13.3 Process Functional Description. Transpurtation from the size reduction and assay facility to interim storage will be via lorklift or lorklili loading the 55 -gal drums onto a llatbed truck. 
4.2.13.4 Reference Baseline Technology. Commercial lorklitt and truck transtier will be used.

\subsubsection{Functional Subelement 14.0 INEL Interim Storage}

4.2.14.1 Technical Background and Assumptions. Interim storiage facilities will be constructed and operated by INEL waste management operattons. Interim storage facilities will accept all elements of the waste stream (hazardous, LLW, low-level mixed. TRU, and TRU-mixed). The interim storage facility will be approved to store RCRA wastes. The interim storage WAC is assumed based upon the INEL TRU WAC."

4.2.14.2 Requirements. The interim storage facility will be capable of storing the packaged waste until the thermal treatment lacility is ready to aceept waste. Waste packange assay data will be retained.

4.2.14.3 Process Functional Description. The inturim storage lacility is a commercially fabricated structure classilied as a low hazard facility per UCRL 15910. Ventilation airllow is controlled and exhausted through HEPA tïlters. Radiation monitoring activities lor alpha, beta, and gamma as well as RCRA contaminants are routine.

4.2.14.4 Reference Baseline Technology. A commurcially labricated structure will be used with commercially standard support and monitoring equipment.

\subsubsection{Functional Subelement 15.0 Transportation to Treatment}

4.2.15.1 Technical Background and Assumptions. The treatment lacility is not collocated with interim storage; however, it is located within the INEL.

4.2.15.2 Requirements. INEL transportation requircments will be used. ${ }^{11.12}$

4.2.15.3 Process Functional Description. A commercial liorklili will be used to load the waste drums onto a llatbed truck and translier to storage.

4.2.15.4 Reference Baseline Technology. A commercial forklift will be used to load the waste drums onto a tlatbed truck and transter to storage.

\subsubsection{Functional Subelement 16.0 Treatment Facility General Requirements}

4.2.16.1 Technical Background and Assumptions. The treatment licility has a classification of moderate hazard per UCRL-15910) and a Radicalctive Solid Waste Facility in accordance with DOE 6430.1A. Section 1324, with selected requirements from DOE 64.30.1 A. Section 1304, for a Plutonium Handling Facility.

The entire thermal processing line can be designed, constructed, and tested to maintain alpha contamination controls.

\subsubsection{Requirements.}

- A minimum ol double confinement in accordance with DOE 6430.1 A shall exist between normally contaminated areas and uncontrolled arcas. 
- Equipment designs and interfaces shall be designed to maintain alpha, beta, and gamma contamination confinument.

- All systems in the treatment lacility shall be designed so that a criticality event cannot occur. The treatment facility will follow criticality control requirements per DOE 5480.5 13 and DOE-ID 5480.5A., "Saliety of Nuclear Facilities." ${ }^{4}$

- These systems shall meet or exceed all Federal, statc, and DOE nuclear systems' standards for explosion proof and fire protection and suppression.

- All systems in the treatment facility will be designed so that personnel exposure to radiation will comply with DOE Order 5480.11.

- All systems in the treatment likility will be designed so that personnel exposure to hazardous matcrials will comply with all applicable OSHA standards.

- The overall treatment lacility and operational systems shall meed the requirements for a Radioactive Solid Waste Facility in accordance with DOE 64.30).1 A. Section 1324.

Additional high-level requirements are contained in Relierence 15.

4.2.16.3 Process Functional Description. The treatment lacility shall be designed in accordance with the restrictive standards of DOE 64.30.1A. Section 1324, with selected requirements from Section 1304, and UCRL 15910. These standards institute special design considerations for handling the waste input and withstanding natural hazard disasters such as seismic activity, high winds, and floods.

Triple confinement (primary, secondary, and lertiary) of the waste shall be maintained between the actual waste stream and environment 10 prevent and/or mitigate any potential releases of hazardous or radioactive material to the environment or public above established release limits.

The entire primary confinement shall be labricaled to minimize the potential for alpha, beta, and gamma contamination leakage to the exterior of the primary conlinement and to minimize boldup areas internal to the primary confinement. Methods to accomplish this shall include

1. Stainless steel seam welded construction

2. Details of labrication to minim c holdup including standardized minimum radius details

3. Once through airllow with tolal sysicm dralt and valcuum control of each subelement

4. Airlocks at the inlet and outlet of the treatment line

5. Normally closed passive internal isolation devices at interlace locations

6. Normally open control signal actively controlled isolation devices

7. Hands off operation. remote directed operations only, and double-lid interlaces for access control. 
4.2.16.4 Baseline Technology. The construction will be commercial design lo specification and a high integrity structure.

\subsubsection{Functional Subelement 17.0 Treatment Facility Receiving}

4.2.17.1 Technical Background and Assumptions. The receiving subelement performs the functions of accepting transported material supplied by the transportation-for-treatment subelement. Temporary storage for queuing may or may not be a required function.

4.2.17.2 Requirements. Waste from the transportation system shall be received and stored until conveyance is ready to accept the waste.

4.2.17.3 Process Functional Description. The tratment lacility receiving station will receive packaged waste in boxes or barrels from the incerim storage lacility. The waste containers will be offloaded from a transport truck to a loading dock using a forklitt. The receiving lacility may provide for short-term storage of the packages. Inventory and other dalta generated from the interim storage process, such as radiation levels, and content descriptions, will be recorded lor processing information. The waste packages will be placed into the beginning of the waste treatment line using a forklift or crane and then placed on a power roller conveyor lor transport into the receiving airlock. The airlock will consist of dual sets of triple doors to regulate the airllow through the airlock and into the primary confinement.

4.2.17.4 Reference Baseline Technology. A commercial lorklili and hoist material handling will be used.

\subsubsection{Functional Subelement 18.0 Treatment Waste Conveyance}

4.2.18.1 Technical Background and Assumptions. The conveyance functional subelement includes all apparatus to convey the retrieved waste or removed overburden within the treatment containment structure.

4.2.18.2 Requirements. The waste conveyance system shall comply with the following:

- Designed to accommodate operations, maintenance, and repair in a beta, gamma, alpha, and hazardous contamination environment

- Operate within the temperature and humidity limits in the containment structure

- Capable of eonveying all the various lorms of wastes within the treatment facility

- Convey necessary process leedstocks and process byproducts

- Not change waste characteristics.

4.2.18.3 Process Functional Description. The traltment system waste conveyance for solid state and liquid state molten waste from the initial airlock to the ending airlock lor storage for transfer to assay is accomplished by 
- Self-powered rollers in the packaged state at the beginning of the process for incoming waste and at the end of the process for packaged monoliths. These types of rollers can be easily removed for replacement when necessary.

- Gravity drop or via gravity assist feed. This is the primary means for conveyance of the waste in the noncontained state from one subelement to the next and dictates the overall layout of the process line from a starting point at an initial high elevation to an ending point at some lower elevation.

- Extrusion of the waste from an extrusion device into and through a feed tube. This type of conveyance enables the leeding of the waste to the next subelement in a regulated uniform and controlled condition llow.

- Ram feeders for transter and rough conditioning of the waste piles within a particular subelement. The rams can be powered electrically, hydraulically, or manually. For this design concept, the rams are powered by electrical power screws (electric motor coupled to leadscrew and rollernuts).

- Gravity assisted rotating conveyors. These types of conveyors (rolary kiln and rotary conveyor) are inclined rotating tubes and use gravity $(0$ help move the waste along the tube axis.

- Buoyancy from the diflerences in density of liquid states between liquid slag and liquid metal.

- Gravity flow of liquid material slag and metal.

The treatment system waste conveyance lor offgals and primary conlinement airflow is derived from the implementation of the contamination control philosophy of once-through system airtlow. This philosophy dictates that airllow shall be from areas of lower contamination to areas of higher contamination. This is aceomplishect by

- Draft control of each subelement in the primary conlinement. Drali control is the regulation of the number of airchanges in each subelement and is accomplished by controlling the differential pressure between subelements (primarily at the interface boundaries).

- Pressure control of each subelement in the primary conlinement. Pressure eontrol of the system is accomplished by providing induced dralt lians at the outlet of the offigas systems with suction heads greater than the sum total of all the individual subelement pressure drops. The entire primary conlinement is under negative pressure (slight to medium vacuum) with the most remote subclement establishing the starting point for pressure control.

To maintain system and subelement dralt and pressure control and maintain a balanced total system through varying process conditions, tIvo olligas systems are dictated. One system is tailored to the subelements that support incineration treatment, and the other system is tailored to the subelements that support the vitrification treatment. The need for two systems is based on the relative size and operating ranges of each system and the types of gaseous by-products requiring treatment. 
The waste conveyance for olligas treatment liquid solutions is by pumps and for sludge and solid wastes by extrusion devices.

4.2.18.4 Reference Baseline Technology. Commercially available or labricalled equipment will be used, such as self-powered roller conveyors, powered rams, and a labricaled structure for gravity transter (drop). See Section 4.2.18.3.

\subsubsection{Functional Subelement 19.0 Size Reduction}

4.2.19.1 Technical Background and Assumptions. Much effort has been spent on characterization of the RWMC buried waste. The basis for characterization are from past reports, sampling programs, and other efforts; however. because past practices allowed for much less stringent disposal methods, a large degree of inaccuracy must be assumed for any published numbers. The thermal treatment scenarios consider the waste input stream to contain these waste categories and contaminated soil in varying amounts and percentages.

The size reduction required for processing is assumed less restrictive than for assay monitoring. Thus, it is assumed that size reduction performed earlier (see subelement 10.0) meets size requirements for follow-on processes within treatment system. Also, it is assumed that interim storage containers will become part of the waste stream and thus must be size reduced.

4.2.19.2 Requirements. The process must be capable of reducing the containers size to meet size requirements of the downstream treatment process.

4.2.19.3 Process Functional Description. This size reduction unit has an input of box or barrel packages containing previously size reduced waste from interim storage activities. The function of this size reduction unit is to size, shred, and mix the container and waste and extrude the resulting waste stream through a nominal 12-in. extrusion tube to the next subclement for gross parameter characterization.

4.2.19.4 Reference Baseline Technology. A commercially available shredder/extruder will be used.

\subsubsection{Functional Subelement 20.0 Pretreatment Characterization}

4.2.20.1 Technical Background and Assumptions. It is assumed that the thermal process treatment owner will require independent characterization data for efficient and sale operations.

4.2.20.2 Requirements. Gross VOCs will be monitored as identilied in Table 2 of Technology Design File (TDF), "BWID System Requirements," SA-2.01" to assist in melter performance and maintain sale operations. Gross radionuclides and radiation levels will be monitored to assist in process salety controls and quality control of the linal waste form. Other gross concentrations of constituents will be monitored that are difticult to process such as chlorides, high vapor pressure metals (HVPMs), and sullur. The constituents that are difticult to process are determined by the melting technology chosen.

Data acquisition will be compatible with downstream processes.

4.2.20.3 Process Functional Description. The waste characterization subelement provides an inspection area that enables the thermal treatment operations personnel to obtain intormation as 
necessary for efficient and safe uperations of the thermal treatment processing subelements. Waste enters the waste characterization chamber through an extrusion tube from the shredder. The waste is then manipulated using a ram device and remote operated manipulators. Normally, hand-held portable instruments are used in conjunction with manipulators, or instruments are permanently mounted on the chamber walls. Valuable inlormation includes combustible/noncombustible mix, rough heating value estimates, identification of large quantitics of difficult to process wastes, such as chlorines, sulfur, nitrates, and aluminum, gross radiation values, and estimates of volatile and semivolatile organics. Remote operated manipulators are provided to manipulate the waste as necessary. A special case waste outlet is also provided by a double-lid barrel passout to remove potential special case waste from the waste stream.

4.2.20.4 Reference Baseline Technology. A commercially fabricated enclosure will be used with commercially available standard equipment, such as manipulators, instruments and detectors (Schilling manipulators and standard detectors).

\subsubsection{Functional Subelement 21.0 Metals Sort}

4.2.21.1 Technical Background and Assumptions. It is assumed that atypical waste is not included in the main waste stream.

4.2.21.2 Requirements. Metals will be sorted from the waste stream. A bulk processing rate will be necessary to be compatible with interlacing subclements.

4.2.21.3 Process Functional Description. Metals are sorted using manual remote operated manipulators in a pick and place mode operated by distance located technicians with remote video.

4.2.21.4 Reference Baseline Technology. Commercially available remote operated manipulators will be used. Commercial remote video will be used.

\subsubsection{Functional Subelement 22.0 The: inal Desorber}

4.2.22.1 Technical Background and Assumptions. Nitrates are assumed to begin decomposing at temperatures as low as $30(1)^{\circ} \mathrm{C}$ when held for a suflicient time (on the order of 2 minutes). Material Safety Data Sheets refer to decomposition at somewhat higher temperatures $\left(400^{\circ} \mathrm{C}\right.$ for potassium nitrate, $3811^{\circ} \mathrm{C}$ for sodium nitratc).

4.2.22.2 Requirements. Waste stream constituents will be healed to a temperature of 300$)$ to $500^{\circ} \mathrm{C}$ and held at this temperature lor a minimum of 2 minules. The desorber must be capable of processing all the waste entering the input side and be capable ol variable temperature control over the 300 to $500^{\circ} \mathrm{C}$ range to accomodate variations in the input feed.

4.2.22.3 Process Functional Description. The waste entering the feed tube is at a nominal $70^{\circ} \mathrm{F}$. The thermal desorber heats up the waste $t 0$ a nominal 300$) 1050\left(0^{\circ} \mathrm{C}\right.$ to initiate decomposition of nitrates, evaporate volatiles and some semivolatiles, dehumidily metal oxides, and dry (moisture) the waste for further incineration. The act of thermal desorption reduces the chances for pulsing in the incinerator and increases the level of operating salely. 
4.2.22.4 Reference Baseline Technology. The equipment subelement will use commercially designed and labricated to specification equipment, employing standard enginecring principles based on proven technology. An external electrically heated thermal tube with contained extruded material flow will be used.

\subsubsection{Functional Subelement 23.0 Incinerator}

4.2.23.1 Technical Background and Assumptions. Incineration/pyrolysis of the waste stream is performed to combust the majority of the combustible portion (including organics) of the waste stream. Low temperature incineration may be preferred for reduction in corrosion and erosion of the incinerator. This also may result in reduction in plugging potential of the ash and residuals in the material handling system.

It is desirable to adopt a design that will produce a minimum oflgats llow rate. This will simplify any necessary offgas treatment system.

The inclusion of an afterburner in the system lollowing the incincrator is assumed to be a requisite for compliance with regulations for destruction of contaminants.

4.2.23.2 Requirements. Incineration/pyrolysis of the waste stream will be performed. Downstream input requirements and system throughput processing rate will be met.

4.2.23.3 Process Functional Description. The incinerator is a propane luel-fired rotary kiln operated in the controlled air mode at substoichiometric to stoichiometric conditions. The temperature is maintained in the range of 14001018180$)^{\circ} \mathrm{F}$. Organics and combustible waste are volatilized for further complete combustion in the alterburner. A pereentage of the lixed carbon, minor products of incomplete combustion, and a high pereentage of the HVPMs remain in the ash stream for further processing in the melter. melter allerburner. and melter offgas system. By maintaining the kiln in the controlled air mode. greater control of combustion can be maintained, pulsing conditions can be lessened or aveided, and products ol high temperature combustion (such as NOx) and ash slagging can be decreased in the kiln. Associated problems with high temperature combustion can be transferred to other components that can be operated in a more controlled fashion. Also, the volume of air required 10 be handled by the incinerator offyas system can be reduced, therefore reducing the overall size of this olfyas system. A recognized problem with operating in this mode is the kiln sensitivity 10 infiltration air. However, this potential problem is partially solved by using an extrusion continuous feed system and is further solved by requiring quality design and fabrication specilications for potential air infiltattion points such as the seals.

4.2.23.4 Reference Baseline Technology. The equipment subclement will use commercially designed and tabricated to specification cquipment, employing standard engineering principles based on proven technology. Propane tire rotary kiln with high integrity rotating seals will be used. Seal technology for alpha will be demonstrated hut not proven (recognized problems with seals for control of alpha contamination).

\subsubsection{Functional Subelement 24.0 Afterburner}

4.2.24.1 Technical Background and Assumptions. The output stream lirum the afterburner is assumed to contain $\mathrm{H}_{2} \mathrm{O}, \mathrm{CO}, \mathrm{CO}_{2}$, and $\mathrm{HVPMs}$ (such as mercury, kiad, cadmium, and arsenic), HVPM oxides, halogens, sulfur compounds, combusted organics, products ol' incomplete combustion, 
particulates, and some radionuclides (C. ${ }^{137}$, potential minor yuantities of TRU oxides, and other LLW radionuclides).

One possible design will maintain the olligas stream lor a minimum time at a minimum temperature (approximately $>2$ seconds at $>185()^{\circ} \mathrm{F}$ ) to ensure complete combustion.

4.2.24.2 Requirements. The afterburner shall ensure $99.9999 c^{\prime} c$ (1 part in $\left.10^{6}\right)$ combustion of all organics in the offgas stream.

4.2.24.3 Process Functional Description. Total system offgas and controlled draft airflow is divided into two offgas systems each with its own alterburncr. Division into (wo) systems is necessary due to the practical limitations and operating ranges associated with the incinerator with its associated draft control airtlow and the melter with its associated dralt control airflow. The two offgas systems, including alterburners, are identical systems. each with the same capacity sized to the larger incinerator system. This arrangement allords full redundancy in allerburners and offegas and draft control airllow cleansing at the expense of running the molter oflgats system under normal operations at a reduced capacity. Capability to transler ollyats cleaning operalions from one system to the other is considered an enhancement of this refierence bascline.

The input to the incinerator afterburner consists of the (1) volatilized gas stream resulting from the incinerator combustion, (2) dralt control airllow from the upstream pretreatment chambers to the initial airlock, and (3) downstream dralt control airllow to the point of the inlet to the melter feed device (mixer/extruder). This total airtlow lirst passess through a dust cyclone to separate large particulate from the gas stream and lecels this particulale back to the ash stream. The gas stream then enters the afterburner that is a vertical chamber maintained at $20(0)$ to $220(1)^{\circ} \mathrm{F}$ and sized to ensure a gas residence time of grealer than 2 seconds. Residence time at temperature is measured by rings of thermocouples located at the ends of the afterburner. The aflerburner is maintained in the excess oxygen mode using oxygen gas injection to ensure complete oxidation of the organics. Temperature is maintained using the heat relcalsed during combustion or by heat input from auxiliary heat sources, such as propane or luel lïed torches or inert gas lired plasma torches. Complete destruction of organics is ensured by the designed residence time at temperature in an excess oxygen environment. Potential operation below design limits that could result in offgas relealse above permit limitations originating from pulses of organic volatiles releised during incineration of a combustible, loaded heterogeneous feed stream is reduced and/or eliminated by over capacity design (or by the high instantaneous heat output capability of the plasma torches coupled with oxygen injection and controlled by sensing and leedback circuitry).

The input to the melter alterburner eonsists of (1) olligas resulting from the melting process of noncombustible material and trom combustion and volaltilization ol residual carryover of combustibles and fixed carbon in the ash stream and (2) drali control airtlow from the melter taps and downstream slag and metals barrel lill and cool down lines to the point of the barrel input and output airlocks. The offgas flow travels through a dust cyclone similar to the incincrator dust cyclone but smaller, and an afterburner and oflgas cleaning system identical to the incinerator ofl'gas system but operated at reduced capacity.

4.2.24.4 Reference Baseline Technology. The equipment subelement will use commercially designed and fabricaled to specification equipment. employing stindard engineering principles based on proven technology. Commercially labricaled refiactory lined ducts will be used that are coupled to refractory lined dust eyclones and coupled 10 relrictory lined allerburner chamber with propane, fuel, or plasma lired auxiliary healing. Standard instrumentaltion and circuitry will be used. 


\subsubsection{Functional Subelement 25.0 Mixer}

4.2.25.1 Technical Background and Assumptions. Incincrator (sutput (subelement 23.0) will be mixed with metals trom subelement 21.0. Flux may be added to meet the input requirements of the oxidizing slag metal/metal tapping melter. The mixer will blend the constituents into a relatively homogenous mix. It is assumed that neither the output of the incinerator/pyrolizer or metals sort require size reduction to ensure the mix is homogeneous enough to meet melter input requirements.

4.2.25.2 Requirements. Feedstock will be mixed and blended.

4.2.25.3 Process Functional Description. The ash stream output from the rotary kiln is combined with a gravity dumped, stored metals stream from the metals sort storage chamber at the output of the rotary kiln. The ash exiting the kiln is at a temperature of $1+(0)(0) \mid S(1)()^{\circ} \mathrm{F}$ and presents a potential materials corrosion problem for the mixcr. The metals are combined with the ash stream resulting in partial cooling of the ash and heating of the metals. The metals ash stream still presents a potential corrosion problem: therefore, the stream is passed through a rotary conveyor to cool the ash/metals stream to a temperature within the operating limits of the melter mixeriextruder. The mixer/extruder also has the capability to size reduce the ash/metals stream in the event any slagging or clumping had occurred in the ash/metals stream. Inputs of additional contaminaled soil and/or solid additives are injected into the mixer lor blending into the ash/metals stream, and this entire melter feed stream is again size reduced 10 an optimum size for input into the melter. The mixer/extruder extrudes the feedstream through a leed tube and into the top of the melter on a continuous or intermittent basis. The extrusion tube, while in the tilled state, acts as a barrier to airflow and as a point of separation between the incinerator olligas system and melter oflgas system.

4.2.25.4 Reference Baseline Technology. A commercially available mixer/shredder/extruder will be used.

\subsubsection{Functional Subelement 26.0 Oxidizing Slag, Oxidizing Metal/Metal Tapping Melter}

4.2.26.1 Technical Background and Assumptions. The composition of the molten slag output stream is assumed to be an iron enriched basalt matrix with dissolved metal oxides and TRU and LLW contaminants. This assumption is based on work as reported in Relerences 17, $18,19$. and 20.

The offgas stream from the high temperature melter is assumed to potentially eontain $\mathrm{H}_{2} \mathrm{O}, \mathrm{CO}$, $\mathrm{CO}_{2}$, and HVPMs (such as mercury, kad, caldmium, and arsenic), HVPM oxides, halogens, sulfur compounds, combusted organics, particulales, and some radionuclides ( $C s^{137}$, potential minor quantities of TRU oxides, and other LLW radionuclides).

The metals eontained in the molten metal output stream are assumed to be mainly iron with other trace metals included.

4.2.26.2 Requirements. Input requirements ol downstream subelements will be met.

Operating temperature will be high enough to melt melals and melt the basaltic soils maintaining an adequate viscosity for the homogeneous slag frit/monolith subelement. The melter output shall contain none of the organic constituents found in the system requirements.? 
A waste will be produced that is no longer considered a hazardous waste per f() CFR 261 , "Identification and Listing of Hazardous Waste."

4.2.26.3 Process Functional Description. The melter is a top loaded, cold wall skull melter equipped with teapot (manometer) type laps lor slag and metals tapping. Heat is supplied to the feedstock and melt by plasma ares operating in the transforred arc mode, and oxygen is injected into the melt by oxygen lances. Slag and metals melt under the combined intense heat of plasma arcs and joule heating effect of operation in the translerred arc mode and partition in the bottom of the melter because of the differences in density between the slag and metal. The slag is less dense than the metal and floats on top of the metal. Melter temperature is in the molten steel range $(>165)^{\circ} \mathrm{C}$, $3000^{\circ} \mathrm{F}$ ). Feedstock enters the top center of the melter through an extrusion tube and forms a cold cap. Turbulence and mixing of the melt are maintained by action of the arcs and current paths, convection currents, and controlling the leedstock input rate from the extruder. Metals and slag are tapped via continuous pour taps. An oflyas line exits the top of the melter to a dust cyctone. Vents in the tap chambers connect to the olligats system and dralit control ducts lirom the barrel fill and cool down lines. Access to the llow lines for oxygen lance removal of potential plugs is a design leature. The entire melter system is maintained within a structurally sound and ventilated separate confinement volume with isolation deviees at the inlets and outlets.

4.2.26.4 Reference Baseline Technology. The equipment subelement will be commercially designed and fabricated to specification equipment, employing standard engineering principles based on proven technology (high-temperature electric are melter with continuous pour slag and metals taps).

\subsubsection{Functional Subelement 27.0 Homogeneous Slag Frit/Monolith}

4.2.27.1 Technical Background and Assumptions. The composition of the molten slag output stream is assumed to be an iron enriched basalt matrix with dissolved metal oxides and TRU and LLW contaminants. This assumption is based on experimental and calculated work as reported in References 17, 18, 19, and 211.

The output of the melter is assumed to be slag frit or monolith, whichever form enables a high quality, high reliability radioactive assay.

4.2.27.2 Requirements. The molten slag will be received from the melter and cast into monoliths or processed into a frit form. The waste form will prevent the release of radionuclides and heavy metals.

4.2.27.3 Process Functional Description. Funclional descriptions are provided for subelement 26.1), Oxidizing Slag, Oxidizing Mulals Mclal Tapping Meller and subelement 35.0, Heat Treat/Controlled Cool.

4.2.27.4 Reference Baseline Technology. An industr; standard, continuous pour melter taps with a gravity feed of material into standard drums (autornatic indexing of drums for fill) for monolith production. Drum till line will be contained withir comencrially labricated and ventilated confinement structure. 


\subsubsection{Functional Subelem‘ nt 28.0 Tapped Metal}

4.2.28.1 Technical Background and Assumptions. No radionuclides. or only very minor quantities of radionuclides, are expected 10 be partitioned into the molten metals stream. The radionuclides are expected to be partitioned into the sling, with potentially some carryover into the offgas system. However, radiological controls must still be emplaced on the metals stream.

The metals contained in the molten metal output stream are assumed to be mainly iron with other trace metals included.

A high reliability assay of the metals is assumed to be possible in the monolith form.

4.2.28.2 Requirements. The mollen metal will be received from the melter and cast into monolith forms.

A waste will be produced that is no longer considered a halatdous waste per 4 (1) CFR 261.

4.2.28.3 Process Functional Description. Functional descriplions are provided for subelement 26.). Oxidizing Slag, Oxidizing Metals/Metal Tapping Melter and subelement 35.0, Heat Treat/Controlled Cool.

4.2.28.4 Reference Baseline Technology. An industry standard, continuous pour melter taps with a gravity feed of material into standard drums (atutomatic indexing of drums lor fill) for monolith production. Drum fill line will be contained within commercially labricated and ventilated confinement structure.

\subsubsection{Functional Subelement 29.0 Offgas Treatment}

4.2.29.1 Technical Background and Assumptions. The oflyas stream to the offigas treatment system is assumed to contain $\mathrm{H}_{2} \mathrm{O}, \mathrm{CO}_{2}, \mathrm{HVPM}$, (such as mercury, lead. cadmium, and arsenic), HVPM oxides, halogens, sullur compounds, combusted organics, particulates, and some radionuclides $\left(\mathrm{Cs}^{137}\right.$, potential minor quantities of TRU oxides, and other LLW radionuclides).

The offgas unabated release calculations are assumed to eonlirm the potential for discharge of radionuclides resulting in effective dose eyuivalents greater than allowable per 40) CFR 61.93, "Emission Monitoring and Test Procedures."

4.2.29.2 Requirements. The olligals treatment system shall clean the oflgass stream of all constituents to allow operations within applicible Federal and stale air permit requirements.

In accordance with DOE 6430.1A."General Design Criteria," 40 CFR 60, "Standards of Performance for New Stationary Sourees." 41) CFR 61. "Nitlional Emissions Standards for Hazardous Air Pollutants," and ANSI N13.1, the ollgas treatment system shall be equipped with air monitoring instruments to detect radionuclides and hazardous constituents listed in the BWID systems analysis requirements. ${ }^{7}$ The tinal released ofligas ellluent shall be monitored for any normally or accidentally release radionuclides via an isokinetic sampling system.

The olfgas system must be maintained al a sulticient negalive pressure 10 draw all gaseous thows through the systems and still maintain adequate negative pressure at the most remote location. 
4.2.29.3 Process Functional Description. The olfigits Ireilment system starts after the

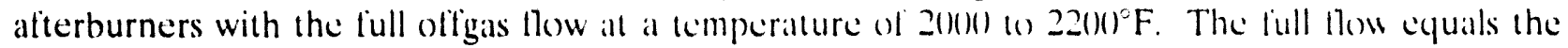
sum of the combustion generated oflgas stream and the drali control generated airllow stream. The full tlow is termed as ofligas because it has gone through the allerburner and must be treated.

The offgas cleaning system presented is used as a relerence baseline system for comparison and scoring only. This system is based on an in silu vitrilicaltion system thall has been demonstrated at tests at the Hanford Site. It is also recognized that this system is not optimal for this treatment process especially concerning the treatment capability for NOx and heavy metals such as lead and mercury but could be optimized during a continued design phase. Offgas systems are typically custom designed for a particular application with the combination of several components each with a particular cleansing ability for a particular olligas product all working as a total system to meet final emissions criteria.

The system presented is a wet system with high lotal system pressure drop that dictates the need for large high vacuum induced dralt suction lans (blowers). Ollgas exits the allerburner at 20)(1) to $2200^{\circ} \mathrm{F}$ and lirst enters a roughing water-based spray yuench chamber to cut the lemperature to approximately to $550^{\circ} \mathrm{C}\left(10000^{\circ} \mathrm{F}\right)$. Spray solution is collected in a sump tank. The ofligas exits this chamber and enters a venturi ejector scrubber where spray solution lluid is injected, atomized by the action of the venturi, and scrubbed by chemical reaction of the small altomized solution and gas stream. Particulates adhere to the atomized droplets and condense into large droplets at the venturi throat because of decreased velocity and a drop in pressure. The large droplets collect, and a solution with scrubbed elements is collected in the tank. The ollgas continues into a hydrosonic scrubber that acts similarly to the venturi but increasingly scrubs the gas strcam. Scrub solution is injected, atomized, and recondensed, and liquid condensate is collected in a sump tank. The hydrosonic scrubber also uses pressure drop to induce llow and scrubbing action. The offigas exits the scrubber and enters a separator. condenser, and a linal separator chain to eliminate line water/solution mist. Solution is collected in a sump tank. Chemistry control is maintained on the scrub solution tanks to maintain effective scrubbing capabilities in the components. The cleaned offgas then passes through a reheater 10 evaperate any remaining mosisture and prevent final filter clogging. The stream then enters a bank of redundant prelilters and linal HEPA lilters. Metal HEPA filters are used for this baseline case (1) enable cleaning via back llushing and lilter mechanical rigidity. The offgas is then drawn into the induced dralt blower fans (point of greatest system vacuum) and is exhausted through the fan/hlowers out the stack. The stack is continuously monitored by temperature, flow, and pressure instrumentation, redundant continuous air monitors (CAM) for radioactivity, and redundant continuous isokinetic air samplers (lilters and sample gas volumes) for laboratory analysis of stack emissions.

Sludge is continuously removed from the collection lanks, compresised to remove liquid, and dried to remove remaining mosisture.

4.2.29.4 Reference Baseline Technology. The equipment subelement system will be commercially designed and labricaled to specilicaltion equipment, employing standard engincering principles based on proven technology (wet venturi olligis cleansing system and HEPA liltering).

\subsubsection{Functional Subelement 30.0 Mixer}

4.2.30.1 Technical Background and Assumptions. Residue trom the ofligas treatment process (subelement 29.0) may not meet the input requirements of the joule healed residue melter (subelement 31.0). Borosilicate glass (BSG) frit will be added as necessary. The mixer will blend the 
residue and BSG trit into a relatively homogenous mix. It is assumed that neith en the BSG frit or oflgas residue require size reduction to ensure the mix is adequalcly homogen

4.2.30.2 Requirements. Focdstock will be mixed and blended to mest melter input requirements. The resulting mix will be transported (1) the joule heated meller.

4.2.30.3 Process Functional Description. The ollyas system residue consists of sludge removed from the wet oftgas system solution tanks. This dried sludge is led into a mixer/extruder and blended with a glass forming feedstock. The mixture is then extruded into and through an extrusion tube into a low-temperature glass melter.

4.2.30.4 Reference Baseline Technology. A commurcially available mixer'shredder/extruder will be used.

\subsubsection{Functional Subelement 31.0 Offgas Residue Melter}

4.2.31.1 Technical Background and Assumptions. Meller temperalture is assumed to be a nominal $20000^{\circ} \mathrm{F}(1100)^{\prime \prime} \mathrm{C}$ ) based on operalling lemperaltures lor mellers designed lor vitrification of high-level waste (HLW) using BSG.

4.2.31.2 Requirements. Operating lemperature will be high enough to melt the BSG firit and residue and low enough to hold the contaminants (HVPMs. motal oxides, radionuclides, etc.) in solution. The output must be compatible with downstream processes. A waste will be produced that is no longer considered a hazardous waste per 41$)$ CFR 261.

4.2.31.3 Process Functional Description. The sludge/glass former mixture is extruded into and through an extrusion tube into the top ol a metal joule healed stirred glass melter. The melt glass product is tapped and deposited into barrels in a barrel lill station. The barrel lill station and transfer line are similar in design 6 the slag and metals lill station and line of the primary melter. Offigas from the meler and drali control airtlow lrom the barrel lill chamber and conveyor line are ducted and routed back to the inlet of the primary meller olligas allerburner.

A recognized alternative to forming a glass product from the oflgats residue stream is a low temperature solidification option using sultur polymer cement. which may result in a better waste form for capturing heavy metals (lead and mercury would still be a problem).

4.2.31.4 Reference Baseline Technology. A commurcially available, medium-lemperature glass melter (stirred glass Inconel 69) joule heilled molter) will he uscel.

\subsubsection{Functional Subelement 32.0 Offgas Frit/Monolith}

4.2.32.1 Technical Background and Assumptions. The composition of the molten slag output stream is assumed to be a BSG matrix with dissolved metal oxides and potentially minor quantities of TRU and LLW contaminants.

4.2.32.2 Requirements. The molten slag will be received from the melter and cast into monoliths or processed into a frit form. Output will be compatible with downstream processes. 
4.2.32.3 Process Functional Description. Descriplions are provided in subclements .31.0), 26.0, and 35.(). The glass product is cast into monoliths forms contained in barrels, decontaminated. swiped, and surveyed as clean before exiting through an airlock lo the storage and transfer station.

4.2.32.4 Reference Baseline Technology. An industry standard, continuous pour melter taps with the gravity feed of material into standard drums (automatic indexing of drums for fill) for monolith production. Drum fill line will be contained within commercially labricated and ventilated confinement structure.

\subsubsection{Functional Subelement 33.0 Post-Treatment Radioactive Assay}

4.2.33.1 Technical Background and Assumptions. It is assumed that pretreatment characterization will not satisty the requirements lor classilying output waste lorm.

An advantage for thermally processing this type of waste is to convert the as received waste stream into a form that will enhance the ability (o) obtain TRU concentration data with reduced uncertainty.

The bases for this reduction in uncertainty of assily data are

- The geometry of the assiay lorm can be uptimized lor the assily equipment (geometry of choice enables consistent geomutrical calibration liactors).

- Vitrification and homogenization eliminate density variances.

- Vitrilication and homogenization eliminate radionuclide distribution variances (fully dissolved radionuclides and complete mixing).

- Vitrification and homogenization enhance the predictability of sell shielding (alpha) unknowns.

- Vitrification and geometry of choice allow lior reduced assay time because of assay of a known form with decreased variances and enable assily data to be collected at a waste throughput rate of tons per day.

- Vitrification and enhanced assaly calpability allow for post-trealtment sort of TRU and LLW based on reliable and consistent assigy dalla.

- Vitrilication and enhanced assay cappability increases the ability to identily radionuclides and quantily concentrations of the radionuclides. This enhanced capability increases the credibility of the data and allows lor lurther rational disposition decisions.

4.2.33.2 Requirements. To mest the assigy requirements, it is necessary to necessary to identify and quantily radionuclides so that wask can be assigned as LLW, reclassilied LLW, or TRU as follows:

- $\quad$ TRU $>10(1) \mathrm{nCi} / \mathrm{g}-\mathrm{TRU}$

- $\quad 10 \mathrm{nCi} / \mathrm{g}<\mathrm{TRU}<100 \mathrm{nCi} / \mathrm{g}-$ reclissilied LLW 
- TRU $<10$ ncig - LLW.

4.2.33.3 Process Functional Description. SWEPP will be used for this function.

4.2.33.4 Reference Baseline Technology. SWEPP will be uscd lor this function.

\subsubsection{Functional Subelement 34.0 Post-Treatment Medium Temperature Fusing/Remelt}

4.2.34.1 Technical Background and Assumptions. This subsystem may be unnecessary if a monolith is cast during initial thermal treatment. The output of litit or monolith from the primary thermal treatment subsystem is dependent on the physical form required to enhance the assay capabilities and produce lower uncertainty reliability assaly data.

4.2.34.2 Requirements. Thu IEB lrit will be cast into an assay compatible physical form.

4.2.34.3 Process Functional Description. The IEB lirit will be lused or remelted and cast into a monolith.

4.2.34.4 Reference Baseline Technology. Mcdium Lemperature melter operating at a nominal $\left.2500^{\circ} \mathrm{F}(1400)^{\circ} \mathrm{C}\right)$.

\subsubsection{Functional Subelement 35.0 Heat Treat/Controlled Cool}

4.2.35.1 Technical Background and Assumptions. The purpose of this functional subelement is to change the microstructure of the cast monolith waste lorm so that the resulting waste form has low leach rate and high durability.

This subelement along with the fusing/remelt subelement may be unnecessary lunctions if assay systems are identified that can provide high quality, reliable data from a monolith cast block direct from the primary thermal process subelement.

4.2.35.2 Requirements. Cooling will be controlled to optimize the microstructure and meet leach rate and durability requirements.

The subsystem shall include nondestructive cest capabilitiss to verily the integrity of the final waste form.

4.2.35.3 Process Functional Description. Cluan empty metal barrels enter a barrel fill chamber through an airlock via a power roller conveyor and are preheated by the ambient temperature within the fill chamber. During the lill sequence, a barrel is positioned under the melter tap opening. The melter tap control is operated, and the molten slag pours out of the tap opening and drops vertically through air lilling the barrel to a preset point. The slag temperature and viscosity are measured during the lill process, and a mollen slag sample is laken using a standard metals sampling cup by a remote operated manipulator. The sample cup is passed out of the lill chamber through a double-lid passout port and analyzed for physical and chemical properties as well as radioactive isotopes. The tap control is operaled again, and the molten slag thow is stopped. The sample is coded to the filled barrel, and the barrel aceepled or rejected lor lurther assay and disposal after the process line on the basis of the simple analysis. Rejected slag harrels are transferred back to the beginning of the line for reprocessing. 
The powered roller conveyor is then inclexed to position a new emply barrel. The barrels advance along the line through an interlace doer inte the controlled cosoling lurnate. The heat treat/controlled cooling lurnace consists of a metals type electric resistance annealing lurnace. The molten slag filled barrels enter the furnace on a powered roller conveyor, and are incrementally transferred ihougi: the furnace at a controlled rate. Temperature at the inlet end is maintained at approximately $1350^{\circ} \mathrm{C}\left(2460^{\circ} \mathrm{F}\right)$, and incrementally reduced and maintained along the length of the furnace to approximately $\left.800^{\circ} \mathrm{C}(1470)^{\circ} \mathrm{F}\right)$. The total transfer time between temperatures is approximately 8 hours. The barrels continuc on the line through a thermal barrier along the powered roller conveyor into a quench chamber. Inside the quench chamber, the temperature of the slag filled barrels is reduced from approximately $800^{\circ} \mathrm{C}\left(1470^{\circ} \mathrm{F}\right)$ to a nominal ambient temperature of $21^{\circ} \mathrm{C}$ $\left(70^{\circ} \mathrm{F}\right)$ by a cooled air quench. Nominal transtier time through the quench chamber is 2 hours. The barrels continue on the power roller conveyor through an interlace deor and into the decontamination and package chamber.

Molten metals are removed by a means similar to the slag with the exception that no altempt is made to control the cooling or quene he metals. The melals are allowed to coot at a nominal rate along the entire length the line and pass into a decontamination and patchage chamber similar to :he slag line.

4.2.35.4 Reference Baseline Technology. The cuuipmunt subclemunt will use commercially designed and fabricated to specilication equipment. emploving standard engincering principles based on proven technology (commercial anncaling furnace using powered rollers for transport and a furnace contained within a structurally sound and ventilated conlincment).

\subsubsection{Functional Subelement 36.0 TRU Packaging}

4.2.36.1 Technical Background and Assumptions. The designated disposition is tor interim storage at the INEL pending resolution and opening of a permancent repository for TRU/TRU-mixed buried waste.

4.2.36.2 Requirements. Packaging requircments shall medt current INEL TRU WAC criteria. 9 .

4.2.36.3 Process Functional Description. In the packaging chamber, the barrel exterior is decontaminated, and a lid is placed on the barrel and sealed. The sealed barrel is then decontaminated swiped and surveyed for hose contaminition. Barrels verilied clean of exterior contamination are transterred out of the packiging arcal through an airlock and into a storage area for transfer back to the receiving area lor rejected barrels or to SWEPP for lurther assay and verification of TRU activity levels $(<10 \mathrm{nCi} g .10161(1) \mathrm{nCig.} \mathrm{or}>1(1)(1 \mathrm{nCi} / \mathrm{g})$ and segregation before disposal into permanent disposal facilitics.

4.2.36.4 Reference Baseline Technology. Commcrcial malcrial handling equipment. overhead crane. lorklifi, and commetcial riddiation swipe and survey instruments will be used.

\subsubsection{Functional Subelement 37.0 Final Package Assay}

4.2.37.1 Technical Background and Assumptions. Previous assays will be performed to verify the level and kind of activity in the waste lorm product. 
4.2.37.2 Requirements. Final assily and exturnal contamination swipe surveys will be conducted for INEL TRU WAC."

4.2.37.3 Process Functional Description. This function entails only a swipe survey to verify the container exterior is free from loose contamination.

4.2.37.4 Reference Baseline Technology. Standard instrumentation will be used for gamma, beta, and alpha radiation contamination swipe and survey, and standard instrumentation will be used for gamma radiation survey of container for shipping manifest.

\subsubsection{Functional Subelement 38.0 INEL TRU Interim Storage}

4.2.38.1 Technical Background and Assumptions. Interim storage lacilitiss will comply with the following:

- Constructed and operaled by INEL waste management operations

- Accept all elements of the waste strcam (hacardous, low-level. low-kevel mixed, TRU, and TRU-mixed)

- Approved lo store RCRA wastes.

The interim storage WAC is assumed to be based upon the INEL TRU WAC."

4.2.38.2 Requirements. Retrievable storage at the INEL will be used.

4.2.38.3 Process Functional Description. The interim storage facility is a commercially fabricated structure classified as a low hazard lacility per UCRL 15910. Ventilation airflow is controlled and exhausted through HEPA lillcrs. Radtiation monitoring activities lor alpha, beta, and gamma as well as RCRA contaminants arc routinc.

4.2.38.4 Reference Baseline Technology. A commcrcially liabricated structure with commercially standard support and monitoring equipment will be used.

\subsubsection{Functional Subelement 39.0 Reclassified LLW Packaging}

4.2.39.1 Technical Background and Assumptions. It is assumed that reclassified LLW has the same INEL WAC as LLW. WAC. ${ }^{10}$

4.2.39.2 Requirements. Packigging and disposal shall be in accordance with INEL LLW

4.2.39.3 Process Functional Description. The barrel exterior will be decontaminated and a list installed. The barrel will then be sealed and surveyed lor loose contamination. Barrels verified free of external contamination will be transferred out of the packaging chamber through an airlock.

4.2.39.4 Reference Baseline Technology. Commcrcial matcrial handling equipment, overhead crane. forkliti, and commercial radiation swipe and survey instruments will be used. 


\subsubsection{Functional Subelement 40.0 LLW Packaging INEL Disposal}

4.2.40.1 Technical Background and Assumptions. The waste derived from tixing the oftgas residue into BSG is assumed to be LLW and melter product $<10 \mathrm{nCi} g$ as determined by posttreatment radioactive assay (subelement 3.3.(1). The potential lor TRU elements to be carried off into the offgas waste stream is considered to be small.

4.2.40.2 Requirements. Packaging shall be in accordance with INEL LLW WAC. ${ }^{10}$

4.2.40.3 Process Functional Description. NA

4.2.40.4 Reference Baseline Technology. INEL LLW WAC will be used. 


\section{SYSTEM PERFORMANCE MEASURES}

\subsection{General}

This section summarizes the values assigned to system performance measures associated with the Retrieve/Ex situ Thermal Treatment configuration option. These measures are delined as system technical or institutional characteristics used as inputs for scoring formulas. These formula scores are multiplied by utility functions and summed in weighted averages to generate the category figures of merit and overall system score in Section 7 of this report.

The numerical values of the system perlormanee measures are derived from published performance data from vendors supplying the equipment or hardwalc used and from engineering estimates.

\subsection{Performance Measure Values}

A list of the system perlormance meisures is provided below. Numerical values for each measure are presented with the basis for that value. The measures are presented in the order in which they lirst appear in "Trade-Olf Study Pertormance Mcasures." TDF No. SA-4.10)3, BWID Systems Analysis. ${ }^{21}$

1. $\quad V_{0}=$ Volume $\left(\mathrm{m}^{3}\right)$ ol output milterial from the process that requires monitoring and storage (includes any contaminated process material)

$$
\begin{aligned}
& =141.391 \mathrm{~m}^{3}\left(185.043 \mathrm{yd}^{3}\right)\left(10.028 .3 \mathrm{~m}^{3} / 1 / \mathrm{i}^{3}\right) \\
& =1,593,921 \mathrm{ft}^{3} \text { (waste }+ \text { soil A4t) mix) }
\end{aligned}
$$

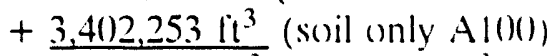

$$
\begin{aligned}
& 4,996,174 \mathrm{lt}^{3}\left(185,\left(14.3 \mathrm{yd}^{3}\right)\right. \text { glass ceramic (IEB) linal waste lorm }
\end{aligned}
$$

The overburden is assumed to be uncontaminalted (Seclion 4.2 .5 .1 ) and $75^{\circ} c$ will be removed before treatment (Section 4.2.5.2).

$12,059,707 \mathrm{ft}^{3}$ total input volume

$-2,740,68.3 \mathrm{ft}^{3}$ removed uncontaminated overburden (.75 overburden)

$9,319,024 \mathrm{it}^{3}$ net volume treated

Waste + Soil Treatment:

Assume 40$)^{\circ}$ base case soil loalding with waske inpul (At) mix IEB $)^{17}$

$$
\text { Container volume }=2 . .325 .251 \mathrm{lt}^{3}
$$

Treated waste $\left.(6)^{c} c\right)$ and soil $\left(4()^{c} c\right)$ volume (Aft) mix):

$$
\begin{aligned}
& 60 \%=2,325,251 \mathrm{dt}^{3} \text { (waste volume) } \\
& \frac{40 \%}{100 \%}=\frac{1,550.167 \mathrm{it}^{3} \text { (soil volume) }}{3,875,418 \mathrm{t}^{3} \text { (A4) waste/soil mix) }}
\end{aligned}
$$

Treated waste + soil linal waste form volume (IEB-Af()): 
Container volume (1/3.72 waskle only reduction liactor)

$2,325,251 \mathrm{ft}^{3}$

$\times 0.269$

$625,067 \mathrm{ft}^{3}$

Soil volume (1/1.60) soil reduction lactor)

$1,500,167 \mathrm{ft}^{3}$

$\underline{\times \quad 0.625}$

$968,854 \mathrm{ft}^{3}$

Total: $625.1667 \mathrm{ft}^{3}$

$$
\frac{968,854 \mathrm{dt}^{3}}{1,593,921 \mathrm{tt}^{3}}
$$

(Approximate $A+4$ ) volume reduction liactor $=2.4 .3 / 1$ ):

$\left(3,875,418 / 2.43=1,594.822 \mathrm{li}^{3}\right)$

Soil only treatment:

Treated soil volume at $\mathrm{A} /(1) \mathrm{mix}(1(1))^{\circ} \mathrm{c}$ soil):

9,319,(1)24 $\mathrm{ft}^{3}$ net treated volume $\frac{-3,875,418 \mathrm{ft}^{3}}{5,443,6() 6 \mathrm{ht}^{3}}$ (1) waste/soil mix

$5,443,6() 6 \mathrm{ti}^{3}$ soil only $(\mathrm{Al}()())$

Treated soil tïnal waste form volume (IEB):

5.443.606 $\mathrm{lt}^{3}$ soil only $(\mathrm{Al} /()(\mathrm{)})$

$\times \quad(0.625$ applied volume reduction liactor (1.60):1): (11.601) soil only volume reduction)

$\frac{x, 4(02,253}{i t^{3}}$ IEB Al()) volume

Compaction Ratio: ${ }^{1 "}$

Soil only

Waste only

Waste + entrained

Waste + entrained + under

Waste + all soil
Slagg (S.G. $=3.2)$

Suil (S.G. $=2 .(1)$

Container volume

Dense waskle

Extraction volume

Waste + entrainced/1.60)

Wisice + (entrained + underburden)/1.60)

Extraction + underburden + overburden $1.81 / 1$

Wask + (all soil)/1.(x) $\underline{\text { Value }}$

$1.6(1) / 1$

$3.72 / 1$ 
Basis is from estimales of volumes and masses trom Pi! y of the SDA with thermal treatment producing a glassiceramic tinal waste lorm."

Offgas treatment systems may need to be accounted fing or explicilly discounted. Residual will ratio approximately $1: 10$ against trit supply" and may allect throughput above.

2. $\quad V_{i}=$ volume $\left(\mathrm{m}^{3}\right)$ of waste seam, matrix, uverburden, and horizontal plume as defined in the input requirements

$=\quad 341,489 \mathrm{~m}^{3}\left(12,059,707 \mathrm{lt}^{3}\right)$

Volumes are as lollows:

$2,325.251 \mathrm{lt}^{3}$ contianer volume

$3,954,692 \mathrm{lt}^{3}$ soil volume (matrix)

$3,654,245 \mathrm{ft}^{3}$ (overburden soil

$2,120,375 \mathrm{fl}^{3}$ underburden (matrix)

$5.144 \mathrm{lt}^{3}$ subsidence

Total $=12,\left(159,707 \mathrm{li}^{3}\right.$

$=341.489 \mathrm{~m}^{3}$

Underburden and soil volume are included in matrix per input requirements.

3. $\quad \mathrm{V}_{\mathrm{g}}=$ volume $\left(\mathrm{m}^{3}\right)$ ol contaminated process malcrial produced by the system

$=10,000 \mathrm{~m}^{3}$

Engineering baseline estimate of constituents of $\mathrm{V}_{\mathrm{g}}$ include

- Operations solid waste (antiCs)

- Contaminated discarded hardware

- HEPA liilters

- Stabilized olligas residual solids.

Note that $\mathrm{V}_{\mathrm{g}}=10.00\left(0 \mathrm{~m}^{3}\right.$ (approximalcly $1(1)$ ) semitruck loads) is an engineering baseline estimate over the life of the project lor relative scoring purposes. Elimination or reduction of operations solid waste, conlaminated discarded hardware, and HEPA lilters, will reduce $\mathrm{V}_{\mathrm{g}}$.

4. $\mathrm{E}=$ mean traction of allowable emissions

$=1$

The range for this measure is from () (1) 1. A value ol zero represents zero emissions (which implies reduced permilting). A value of 1 represents the maximum quantity of 
emissions allowed by the approsed permits and licenses lor operations. New or improved technologies that reduce any or all emissions will reduce this measure (example, if a new technology enables emissions (o) be reduced to the soloc level. then $\mathrm{E}=(1.8)$

5. $\mathrm{E}_{\text {ret }}=$ mean fraction of allowable emissions

$$
=1
$$

This will equal $E$ for the technology relerence baseline system, but $E$ may change as different technologies are considered.

6. $\mathrm{F}_{\mathrm{s}}=$ COTS tunctional subelements

$=\quad 31.7$

COTS are those components that are not designed and labricaled only lor the application in the design concept. The fraction of COTS rellects the major interlated eomponents within a subelement that can be recenligured (or that have standard interfaces) and are COTS. $F$, is an input to the reconligurability performance measure, and thus cost is not used as a metric in the calculation below.

COTS fractions are engineering estimalles based on vendor surveys and reviews of similar systems.

Number Subclement

COTS Fraction

1. Site/Waste Characterization

Commercial water well drilling technolegy

to obtain depth to bassalt and cutlings samples

for analysis of contaminants. Records review

for estimation of houndaries and variely ol

contaminants disposed.

2. Belowgrade Isolation

1

Sheet piling and H-pilings, commercially

availible and used in the mining industry.

3. Abovegrade Containment

0.5

There are three containment structures. Each is manulactured 10 specilication. Air filtration system is COTS.

4. Overburden Characterization

Standard equipment. 
5. Overburden Removial 1

Systum is COTS.

6. Storage of Contaminated Overburden

Fabricate to specifications.

7. Noncontaminated Overburden Storage $\quad 0.7$

Fabricated to specifications.

8. Retrieval 0.7

Modified commercial éyuipment, labor intensive.

9. Waste Conveyance 0

COTS elevators will be highly modilied.

10. Size Reduce

Highly modilied commercial equipment and housings.

11. Radioactive and VOC Assily

SWEPP similar equipment and procedures. Accuracy and reliability of data sullicient for pretreatment data collection and characterizallion. System is fabricate to specilication with commercial equipment.

12. Packaging

Standard equipment and procedures.

13. Transportation 1.0

14. INEL Intcrim Storagl

Building is labricate to specilication. Intrabuilding conveyance is COTS.

15. Transportation to Trualment

Transport truck, loading and device(s) are COTS. 
Building is labricalte to specilicaltion. Comsyance (crane or forklift) and handling (lorklili) is COTS.

18. Treatment Waste Conveyance

Components of the treatment system waste conveyance

for solid state and liquid state molten waste trom

the initial airlock to the ending airlock for storage

for transfer to assay are separatcly considered below:

a. Self powered rollers in the packinged stille at the beginning of the process lor incoming waste and all the end of the process lor packaged monoliths.

These are COTS and are used by the commercial glass industry and for gencral material handling applications.

b. Gravity drop or gravity assist leed. Feed lunction only components are labricate to specilication. Dual use components (such as the rotary kiln) are COTS.

c. Extrusion of the waste lrom an extrusion device into and through a leced tube. Extruder and leed tube is COTS.

d. Electrical, manual, or hydraulic Ram feeders lor transter and rough conditioning of the waste piles within a particular subelement. These are design lo specilication.

e. Gravity assisted rotating conveyors. These types of conveyors (rotary kiln and rotary conveyor) are inclined rotating tubes and utilize gravity to help move the waste along the tube axis. This type ol conveyor is commercially available and is assumed to be COTS.

i. Buoyancy due to the diflerences in density of liquid states between liquid slag and liquid metal.

g. Gravity tlow of liquid material slag and metal. Containment and guidance of the llow is COTS.

The treatment system wasste conveyanee lor ofligas and primary conlinement airllow is derived from the implementation of the contamination control philosophy of once-through system airllow. This philosophy diclates that airtlow shall be from areals of kower contamination to areass ol higher eontamination. This is accomplished by 
(1) Draft control of each subelement in the primary confinement is accemplished by eontrolling the differential pressure between subelements (primarily at the interlace boundaries). Fans, valving, and controls are COTS. Support structure, ducting, and containment are liabricated (o specilication.

(2) Pressure control of each subelement in the primary confinement. Pressure eontrol of the system is accomplished by providing induced dralt lans at the outlet of the ofligas systems with suction heids greater than the sum total of all the inclividual subelement pressure drops. The entire primary conlinement is under negallive pressure (slight 10 medium vacuum) with the most remote subelement establishing the starting point lor pressure control. COTS and nonCOTS compronents same as (1) above.

To maintain system and subelement dralt and pressure control and maintain a balanced total system through varying process conditions. Iwo olligas systems are dectated. One system is tailored to the subelements that support incincration treatment, and the other system is tailored (1) the subelements that support the vitrification treattment. The need lor two systems is based on the relative size and operating ranges of each system types of gasecous by-products that require treatment.

The waste conveyance lor oflgass treatment liquid solutions is by pumps and lor sludge and solid wastes by extrusion devices.

19. Size Reduction

Shredders are assumed. These are commercially available and widely used in the hazardens and municipal solid waste industry.

20. Pretreatment Characturizalion

Commercial hand held and wall mounled instrumentation. Manipulatoss and double-lid passout are COTS. Ram. enclosure, and isolation gates are labricale (o) specification. 
21. Mctals Sort

Manipulators, manipulator tos)s, magnet(s), metal transfer cart, double-lid passonut, extruder, and extrusion tube are COTS. Ram, enclosure, and isclation gates are labricale to specilication.

22. Thermal Desorber

Resistance heater external to extrusion tube. COTS.

23. Incinerator

COTS rotary kiln. Alpha control scals are labricale to specilication per patented design. Howerer. reliability of seals is unprosen; therelore, value is discounced (o) 19.5 .

24. Alterburner

Fabricate to specilicaltions.

25. Mixer

Modilied commercial equipment.

26. Oxidizing Slag and Metal/Metal Tap Moller

Moditied commercial equipment of libbricale to specilication. Customized. enhanced operating procedures.

27. Homogeneous Slig Frit/Monolith

Moditied commercial equipment and operating procedures.

28. Tapped Metal

Modilied commercial equipment and operating procedures.

29. Otlgas Treatment

Fabricate to specilicaltion.

30. Mixer

Modilied commercial equipment.

31. Otlgas Residuc Muller

Modilied commercial equipment. 
32. Ollgas Frit/Monolith

Modified commercial equipment and operatting procedures.

33. Post-Treatment Radioactice Assily

SWEPP similar equipment and procedures. Limiled proven accuracy and reliability for low specilic activity measurements.

34. Post-Treatment Fusing/Remclt

Dummy variable for consistency. Subelement combined with controlled cooling.

35. Heat Treat/Controlled Cond

Modilied eommercial equipment.

36. TRU Waste Packaging

Standard packaging.

37. Final Package Assay

Standard instruments.

38. INEL TRU Intcrim Storage

Fabricalte lo specification discounted becaluse of W WAC and operating unkmowns.

39. Reclassitied LLW Packanging

Standard equipment and procedures.

40. LLW Packaging INEL Disposail

Standard equipment and procedures. Existing WAC.

7. $F_{1}=$ Total lunctional subclements

$=4(1$

The configuration option functional subelements are

1. Site/waste characterization

2. Belowgrade isolation

3. Abovegrade containment

4. Overburden characterizalion 
5. Overburden removal

6. Storage of contaminated overburden

7. Noncontaminated overburden storage

8. Retrieval

9. Waste conveyance

10. Size reduce

11. Radioactive and VOC assily

12. Packaging

13. Transportation

14. INEL interim storage

15. Transportation to treatment

17. Treatment facility receiving

18. Treatment waste conveyanci

19. Size reduction

20. Pretreatment characterizaltion

21. Metals sort

22. Thermal desorber

23. Incincrallor

24. Alterburner

25. Mixur

26. Oxidizing slag, oxidizing metal metal tapping melter

27. Homogeneous slag lrit/monolith

28. Tapped metal

29. Offigas treatment

30. Mixer

31. Olfyas residue melter

32. Offigas trit/monolith

33. Post-treatment radionactive assily

34. Post-treatment medium temperatture lusingemelt

35. Heat treat controlled (o)

36. TRU waste packaging

37. Final package assialy

38. INEL TRU interim storige

39. Reclassitied LLW packaging

40. LLW packaging INEL disposal.

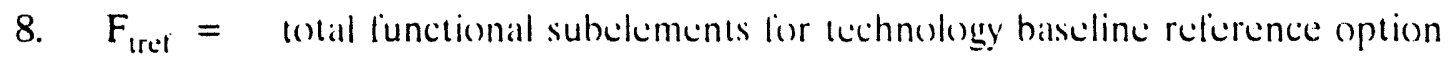

$$
=4(1)
$$

This equals $F_{1}$ lor the cochnolugy bascline system. Note that $F_{1}$ may change as technologies are assessed that increase or reduce the number of subelements with the process option.

9. $\mathrm{N}_{\mathrm{OS}}=$ number of predelined out of scope input that the system can remediate

$$
=8
$$


Engineering baseline estimite lor the delined in-seope waste stream is the buried waste located at the RWMC. Engincering bascline estimate is that the system can remediate the following solid waste streams:
1. LLW
2. MLLW
3. Alpha LLW
4. Mixed alpha LLW
5. Mixed TRU (non-WIPP certiliable TRU)
6. TRU
7. Municipal
8. Sanitary.

Estimate derived lrom review of declared waste streams on the INEL as listed in the INEL roadmap document. $2=$

10. $\mathrm{N}_{\text {ref }}=$ number of predelined aut of secepe inputs the baseline relierence system ean remediate

$=8$

This is equal to $\mathrm{N}_{\mathrm{OS}}$ lor the refierence bascline lechnolugy option.

11. $\mathrm{T}_{1}=$ time until line item and cappital equipment replacement costs exceed $50 \%$ of acquisition cost

$=15$ years

Engineering baseline estimate is that for the length of the remediation aclivity ( 8.3 years). The replacement costs will be kess than sole of the acyuisition costs.

12. $T_{r}=$ lime (t) remediale $V_{\text {, }}$

$=8.3$ years

Engineering baseline estimate for nominal size operational throughput rate of approximately $15 \mathrm{ton} / \mathrm{h}$ at 60$)^{\prime} c$ availability. This estimate was derived by $\mathrm{Vi}=12,059,707$

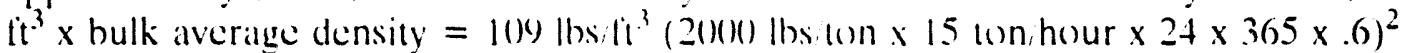

Total waste volume $=24^{\circ} \mathrm{c}$ ol lotal input volume. This consists of metals $\left(22^{\circ} \mathrm{c}\right.$ of waste fraction at $\left.96 \mathrm{bb} / \mathrm{lt}^{3}\right)$. sludge $\left(33^{c} \mathrm{c}\right.$ of wiste volume all $\left.67 \mathrm{lb} / \mathrm{t}^{3}\right)$. combustibles $(20 \%$ of waste volume at $\left.17 \mathrm{hb} / \mathrm{ht}^{3}\right)$, other $\left(25 \mathrm{c}^{\circ} \mathrm{c}\right.$ of waste volume at $\left.40 \mathrm{lb} / \mathrm{lt}^{3}\right)$. Total soil volume $=$ $76 \mathrm{C}^{\circ} \mathrm{c}$ of total input volume. Soril at 2.1$) \mathrm{gec}(\mathrm{S} . \mathrm{G} .=2.0)=125 \mathrm{lb} / \mathrm{tt}^{3}$.

Average density $=.76(125)+.24(56.6)=101.6 \mathrm{lb} / \mathrm{li}^{3}$

13. $\mathrm{A}=$ availability

$$
=0.60
$$


Engineering baseline estimalle is produclive operaltions (trealting waske) of 3 shifis per day (24 h/day) running 5 days per weck. with normal mainlenance aclivitics occurring on the weekend on a 3 shift per day operation.

Semiannual shutdowns of 1 month duration (60) day/year), 3 shift operation ( $24 \mathrm{~h} /$ day) for extended maintenance, repair, and decontamination activities.

$$
\begin{aligned}
A & =\frac{(365-60) \text { days } \times(7-2) \text { dilys } / 7 \text { days } \times 24 \mathrm{~h} / \mathrm{dal}}{365 \mathrm{~d} \text { divs } \times 24 \mathrm{~h} / \mathrm{day}} \\
& =5225 \mathrm{~h} / 8760 \mathrm{~h} \\
& =0.60
\end{aligned}
$$

14. $\mathrm{T}_{\mathrm{h}}=$ Time to remedialte 50$)^{\circ} c$ of $\mathrm{V}_{\mathrm{1}}$

$$
=\quad 4.2 \text { years (one-hall lotal period) }
$$

The year total is an enginecring baseline estimalc based on linciar remediation efforts (takes one-hall the time to remedialc onc-hall the watste).

15. $\mathrm{T}_{\max }=$ maximum time (years) allowed for the remediation process

$$
=20 \text { years }
$$

Estimated start year 2000), complete 2020.

16. $\mathrm{C}_{\text {is }}=$ important-to-salicty capitial expense

$$
=\$+5.1 \mathrm{M}
$$

Important-to-salcty capital estimalled expense is $\$ 45.1 \mathrm{M}^{23}$

17. $C_{m}=$ cost (lile cycle)

$$
=\$ 511 \mathrm{M}
$$

This is an estimated operational lifi cycle cost. Total sitimated cost is $\$ 511 \mathrm{M}^{23}$.

18. $\mathrm{C}_{\mathrm{d}}=$ number of subelements demonstraled under similar site and waste conditions

$$
=34
$$

All subelements blocks with the exception of those listed below are judged to have been demonstrated as adequate for the scope of this conliguration option. 
- Subclement s.(). Retricval

- Subelement 11.0, Radioactive and VOC Assaly (particularly VOC assay at high throughput rate)

- Subelement 26.0, Oxidizing Slag, Oxidizing Metal/Metal Tapping Melter

- Subelement 31.0, Offgas Residue Melter

- Subelement 33.0, Post-treatment Assay (bclow $10 \mathrm{nCi} / \mathrm{g}$ )

- Subelement 35.10. Heat Treal Controlled Conl

19. $\mathrm{C}_{\mathrm{s}}=$ number of subelements similar to a lechnology demonstrated under similar site and waste conditions

$=5$

Functional subelement 33.0). Pust-Treatment Assay (below 10 nCi/g), nor has a similar technology been demonstrated under the eonditions stated. Other undemonstrated technologies listed under item is have had similar lechnologies demonstrated under similar site and waste conditions.

20. $R_{p}=$ hazard index with process (relerence $10^{-13}$ )

$$
=1
$$

This value represents remediation of existing conditions to minimum acceptable levels.

21. $\mathrm{R}_{\mathrm{np}}=$ hazard index without process (retirence $10^{-6)}$ )

$$
=5
$$

This value represents an engincering estimate lor the purpose of this report only and does not rellect any known or published data by others. This value rellects judgement that remediation activities are required $l o$ be perlormed.

22. $\mathrm{R}_{\mathrm{pc}}=$ excess lifetime cancer risk with process

$$
=1 \times 10^{-6}
$$

Short-term worker. including radionuclides and nonradionuclides. As above, this value represents an engineering estimale for the purpesse of this report only and does not reflect any known or published data by others. This value rellects judgement that remediation activities are required to be perlormed.

23. $\mathrm{R}_{\mathrm{npc}}=$ excess lifetime cancer risk without process

$$
=5 \times 10^{-1}
$$


Future no action, average resident, including radionuclides and other carcinogens. This value represents remediation of existing conditions to minimum acceptable levels.

24. $\mathrm{C}_{\mathrm{n}}=$ number of subelements not able to be demonstrated prior to full scale implementation

$=0$

Note that $C_{t}=C_{n}+C_{s}+C_{d}+$ dissimilar demonstrable subelements.

25. $\mathrm{N}_{\mathrm{p}}=$ estimated gross number of permits required

$=8$

A listing of major permits or licensess required is below.

1. Idaho State Facility Siting License

2. RCRA Part A and B

3. Prevention of Signilicant Detcrioration Permit (Air Emissions - Idaho)

4. National Emission Standards for Hazardous Air Pollutants (NESHAPS) Approval to Construct (mercury emissions)

5. Idaho Air Quality Permit to Construct

6. National Pollution Discharge Elimination System (NPDES) permit

7. Wastewater Land Application Permit (Idaho)

8. NRC Operating License

Note that archeological, endangered species (ESA), and historic (NHPA) permits not included or considered. ${ }^{24}$

26. $\mathrm{W}_{\mathrm{no}}=$ volume of waste that cannot currently be moved to oflisite disposal

$$
=()
$$

Engineering baseline estimate is that all waste treated can be moved to offsite disposal.

27. $\mathrm{L}=$ operation labor hours

$=219.450 \mathrm{~h}$

A 5225 operation h/year x 10 year $\times 42$ mean full time equivalent (FTE)/shift.

28. $\mathrm{O}=$ operation hours

$=52.250 \mathrm{~h}$

A $5225 \mathrm{~h} /$ year $\times 10$ year. 
29. $y_{E D}=$ mean years ol specialized training (aciakmic and liacility specilic)

$=2.8$ years/person

Summary of stall lollows:

Position

Number

Years

General and Administrative

Manager

Supervisor

\section{Characterization/Retricval}

Supervisor

Technicians

Laborers

Interim Disposition

Technicians

Laborers

Storage/Transport/Receive

Technicians

Laborers

Sizc Reduce/Assay

Technicians

Laborers

Sort

Technicians

2

Treatment

Supervisor

Technicians

Laborers

Assay

Technicians
5

45

20)

10)

10

5

0.5

5

0.5

$\begin{array}{ll}1 & 5 \\ 3 & 0.5\end{array}$

15

60.5

35

30.5 
Post-Treat

Technicians

6

5

Laborers

3

0.5

\section{Package/Disposition}

Supervisor

Technicians

Laborers

people

person year
10

5

0.5

351

$126 / 3=42$ mean FTE shili

$351 / 126=2.8$ average ycals ed/purson

30. $y_{\text {ret }}=$ mean years of specialized training (academic and lacility specilic) for the reference baseline technology option

$=2.8$ year

This is equal to $y_{E D}$ for the refierence baseline technology option. Note that $y_{E D}$ may change as various technologies are considered.

31. $T_{d}=$ total critical path time to demonstrate

$=24$ months

Engineering baseline estimate is lior a 2 year design and construction schedule prior to operation. Time until demonstration and time until operation are the same.

32. $\mathrm{T}_{\mathrm{br}}=$ time to begin remediation

$=7$ years

Seven years is an enginecring basclinc estimale based on remediation activities starting in the year 200(), which is based on policy decisions (record of decision). 


\section{TRADE-OFF SCORE SUMMARY}

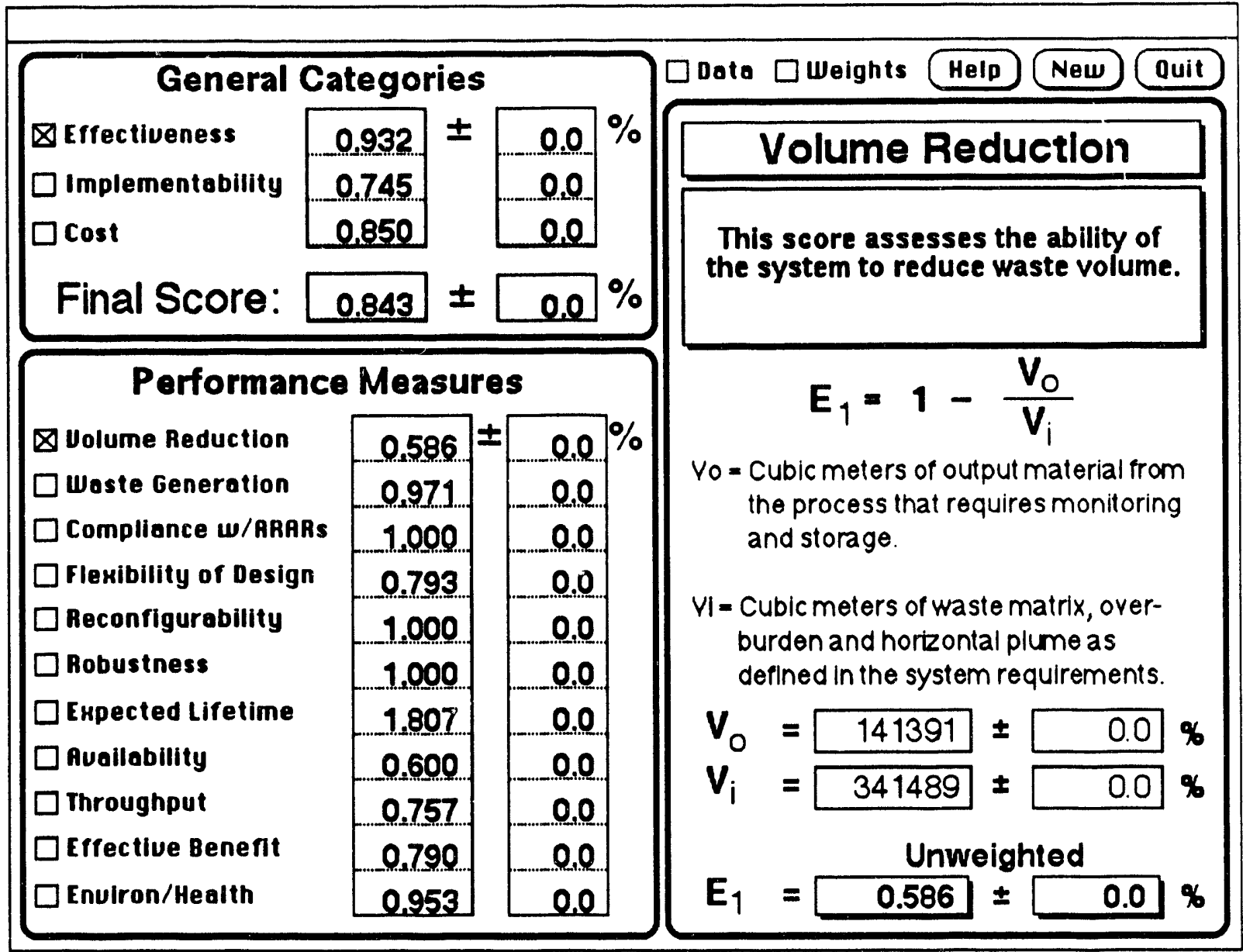




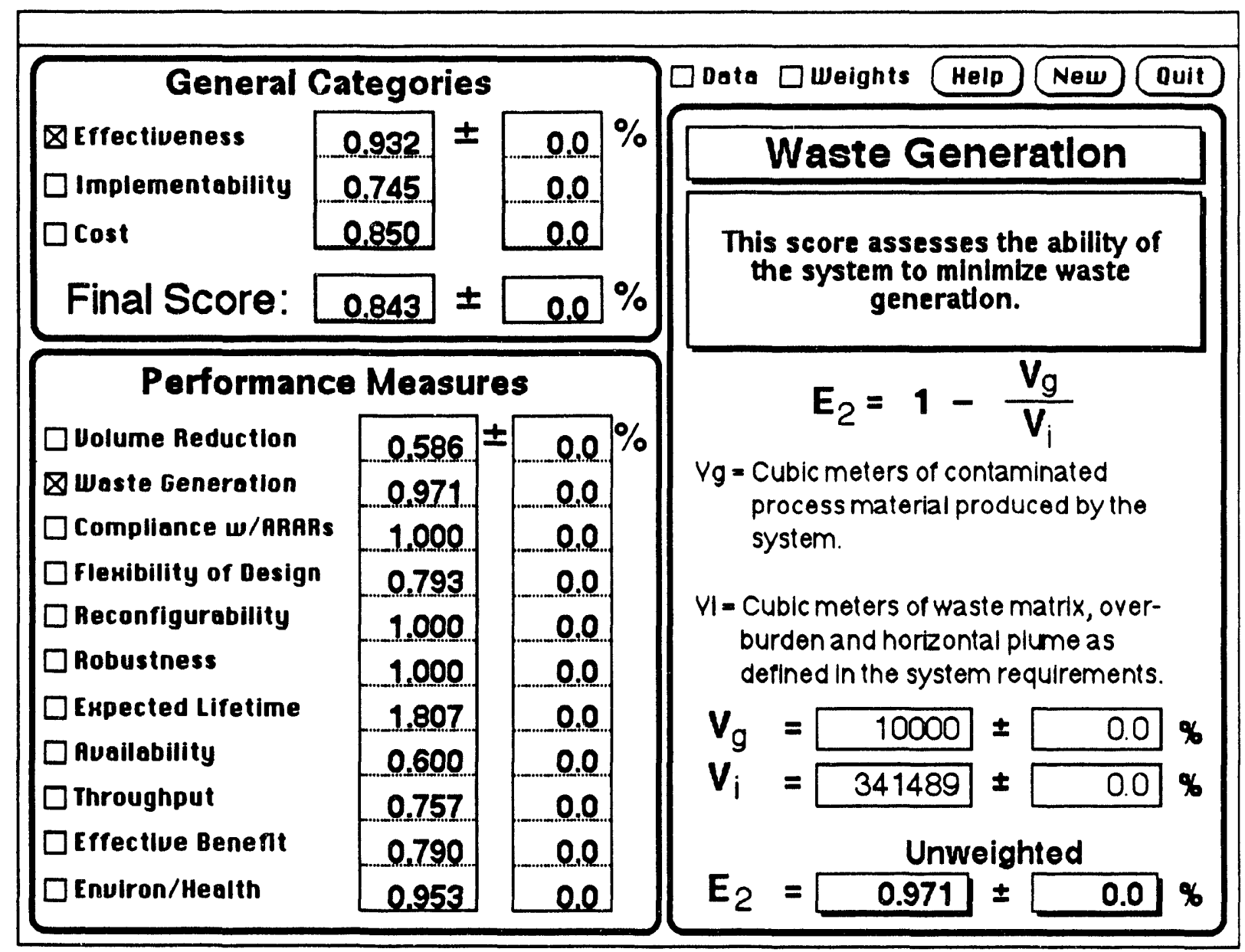




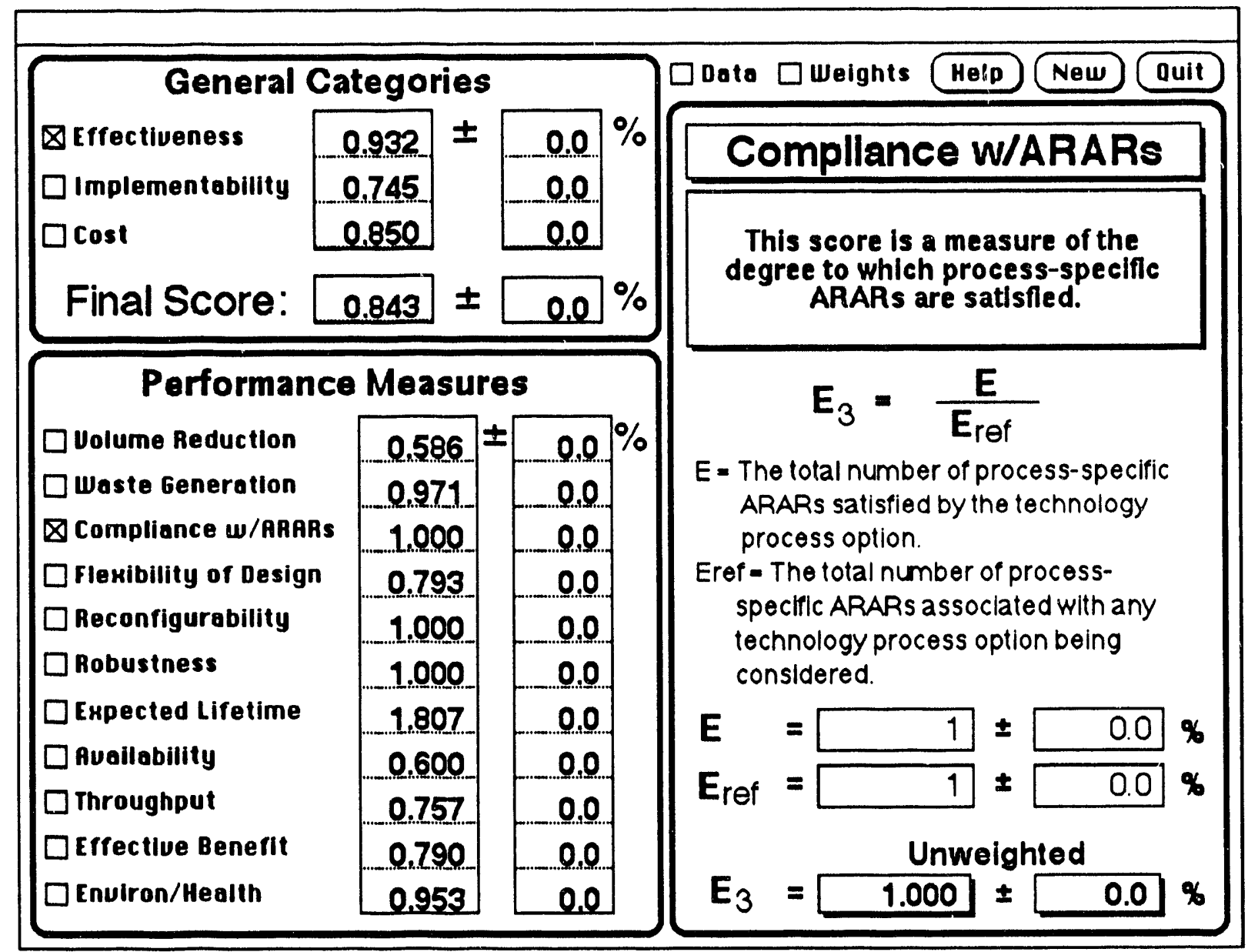




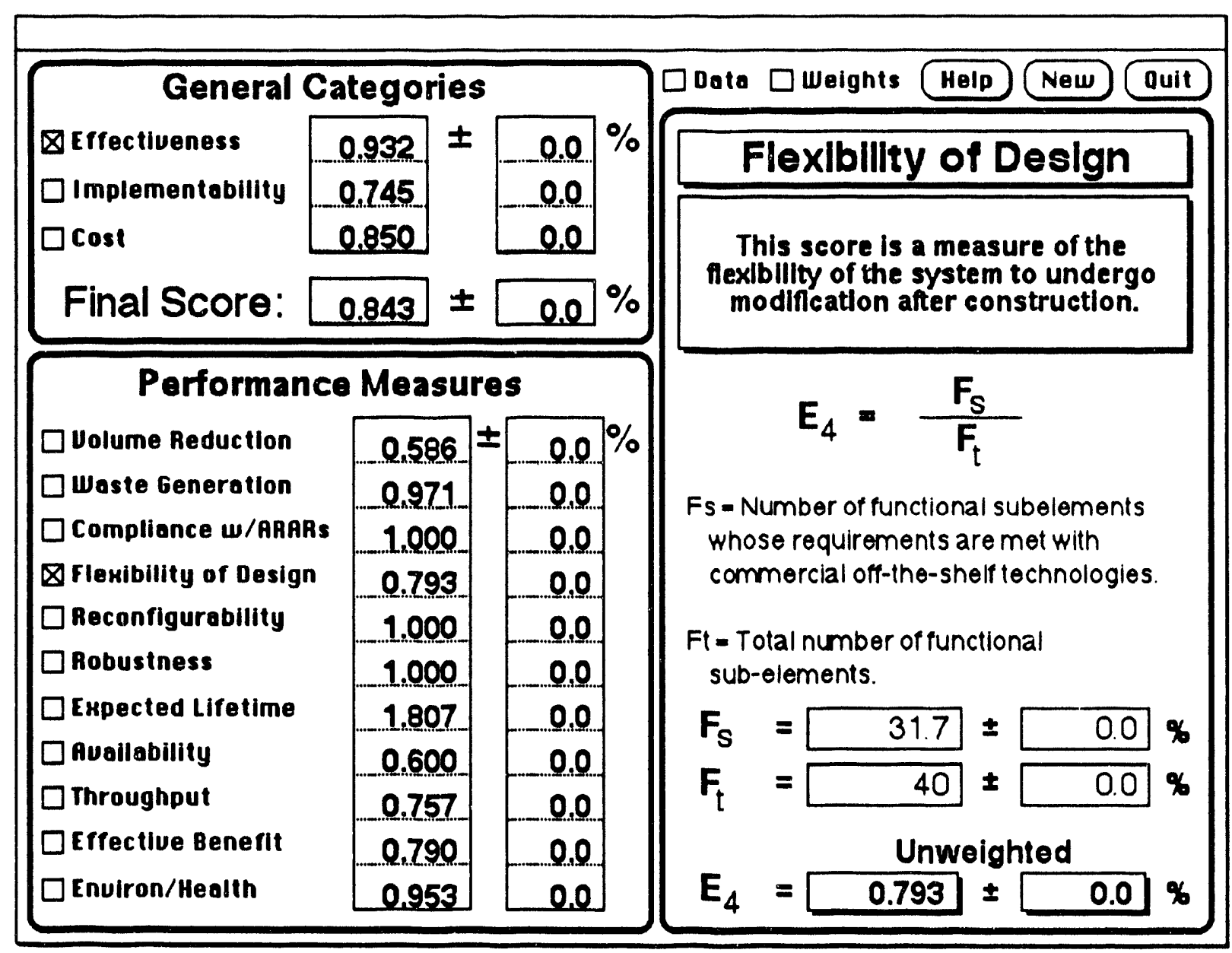




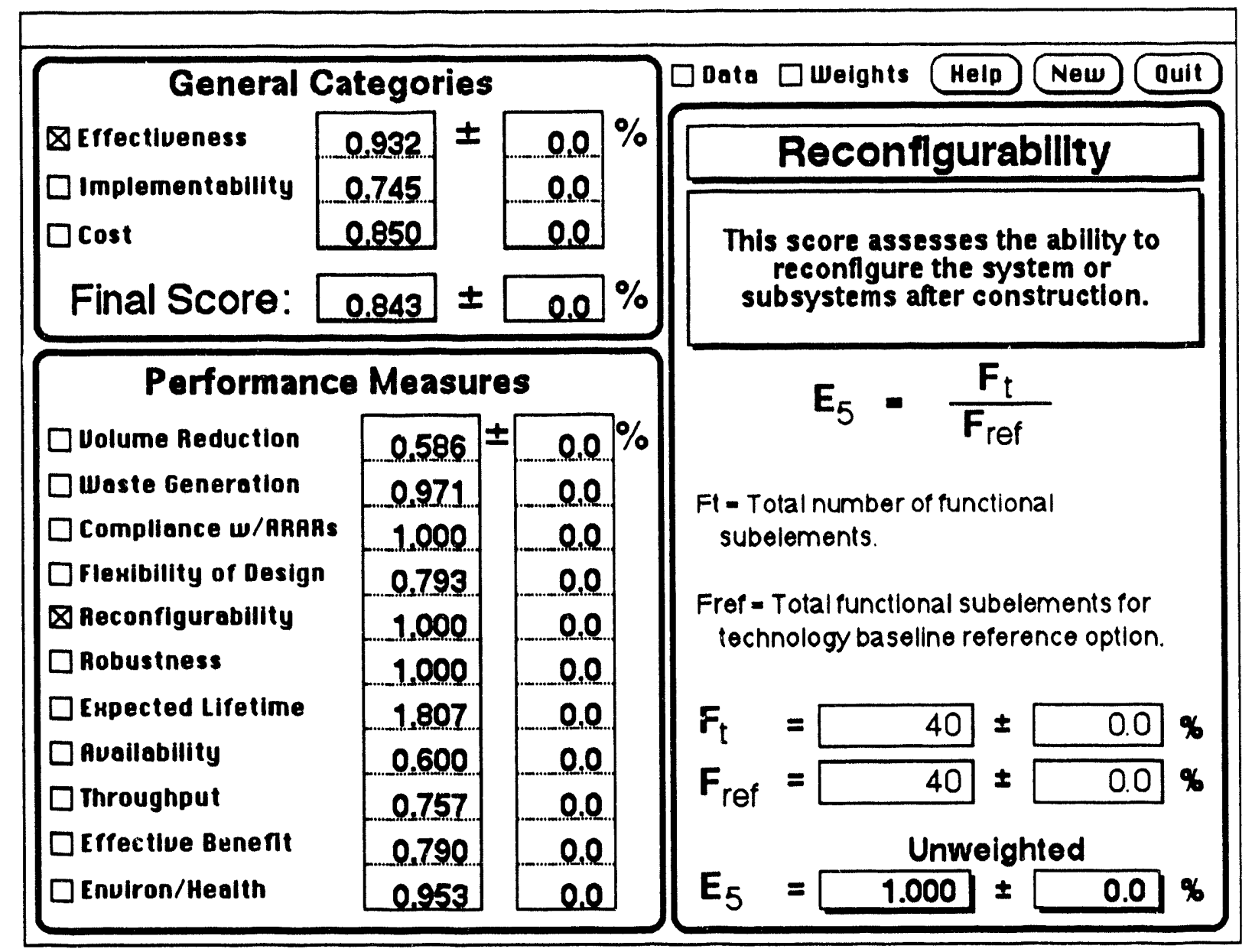




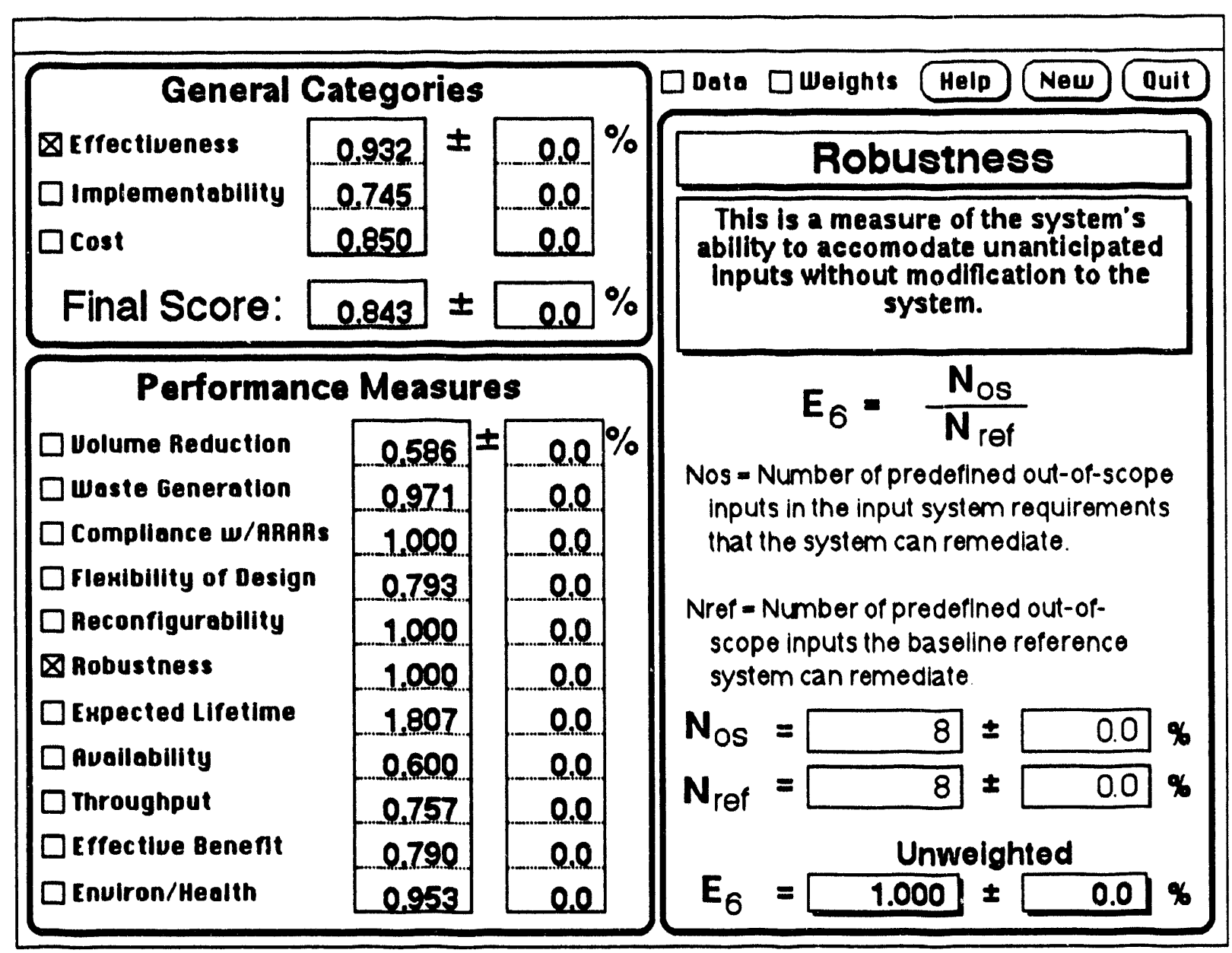




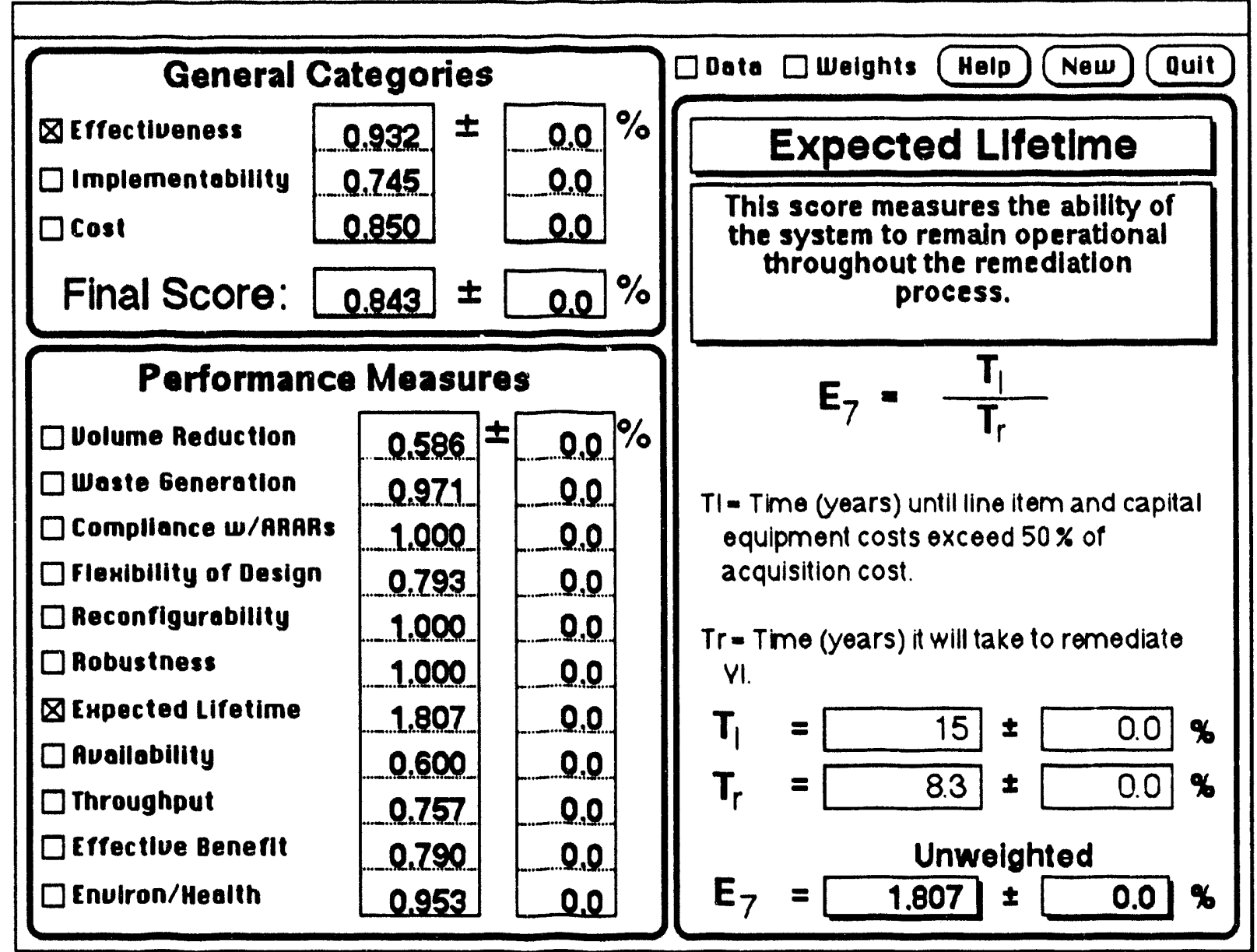




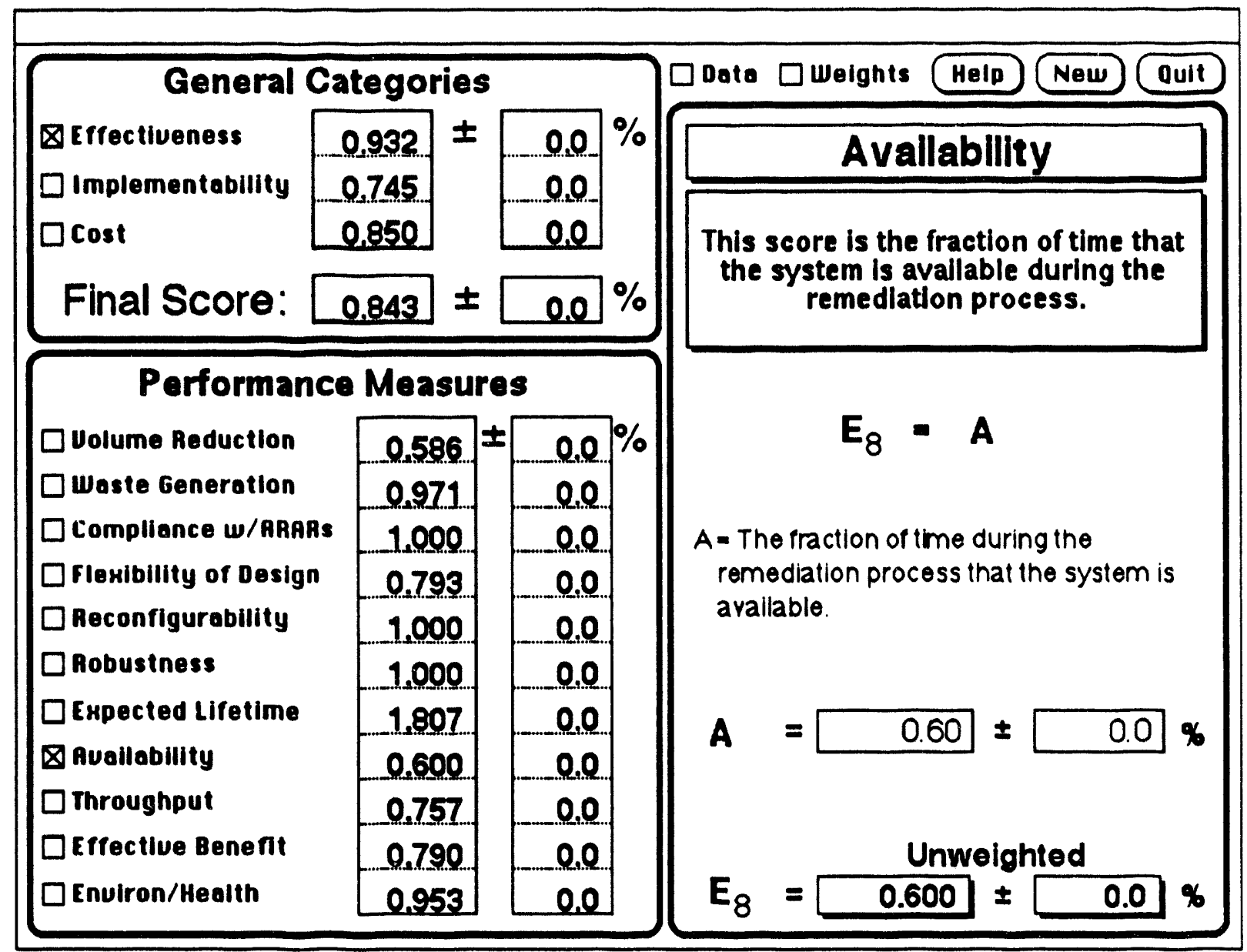




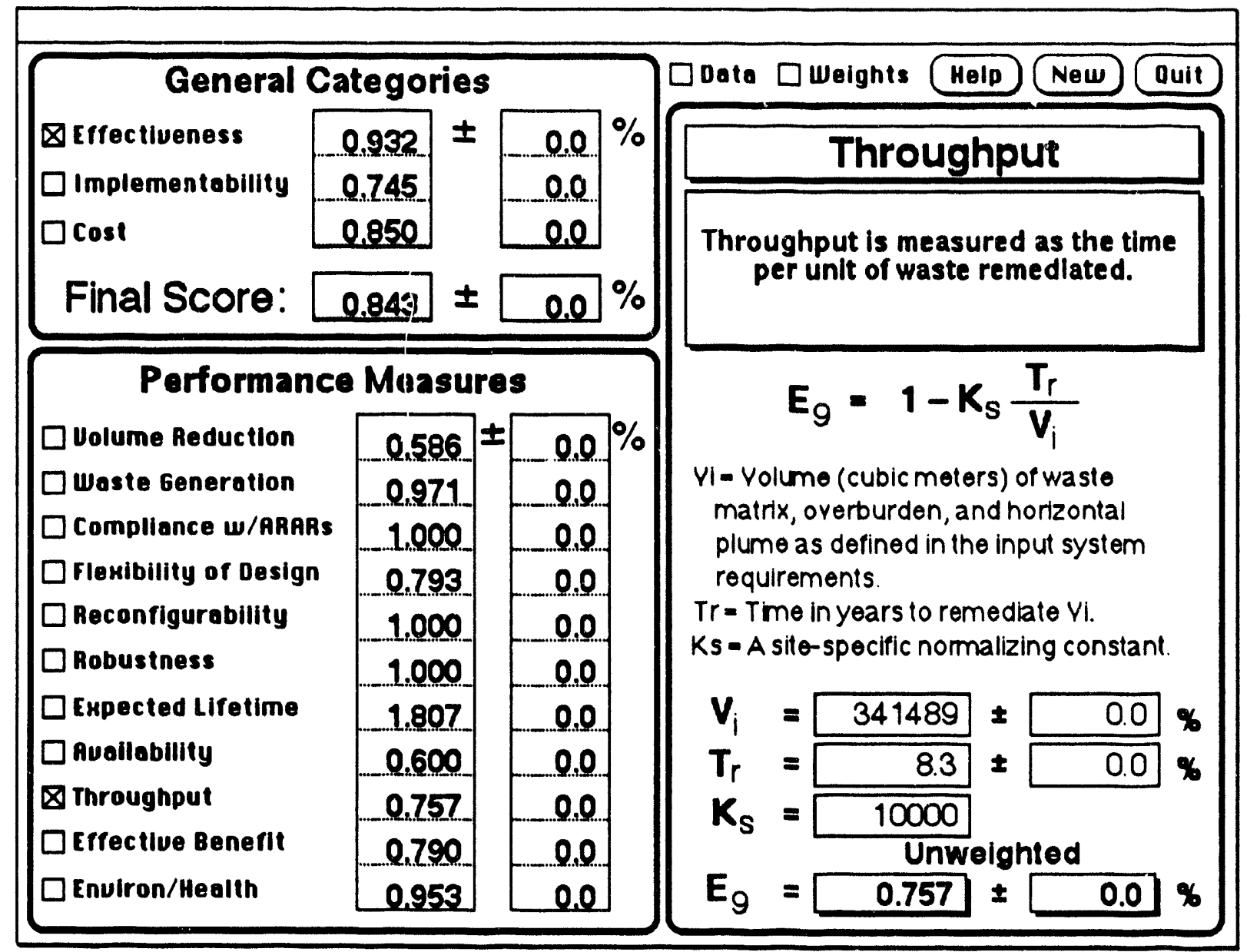




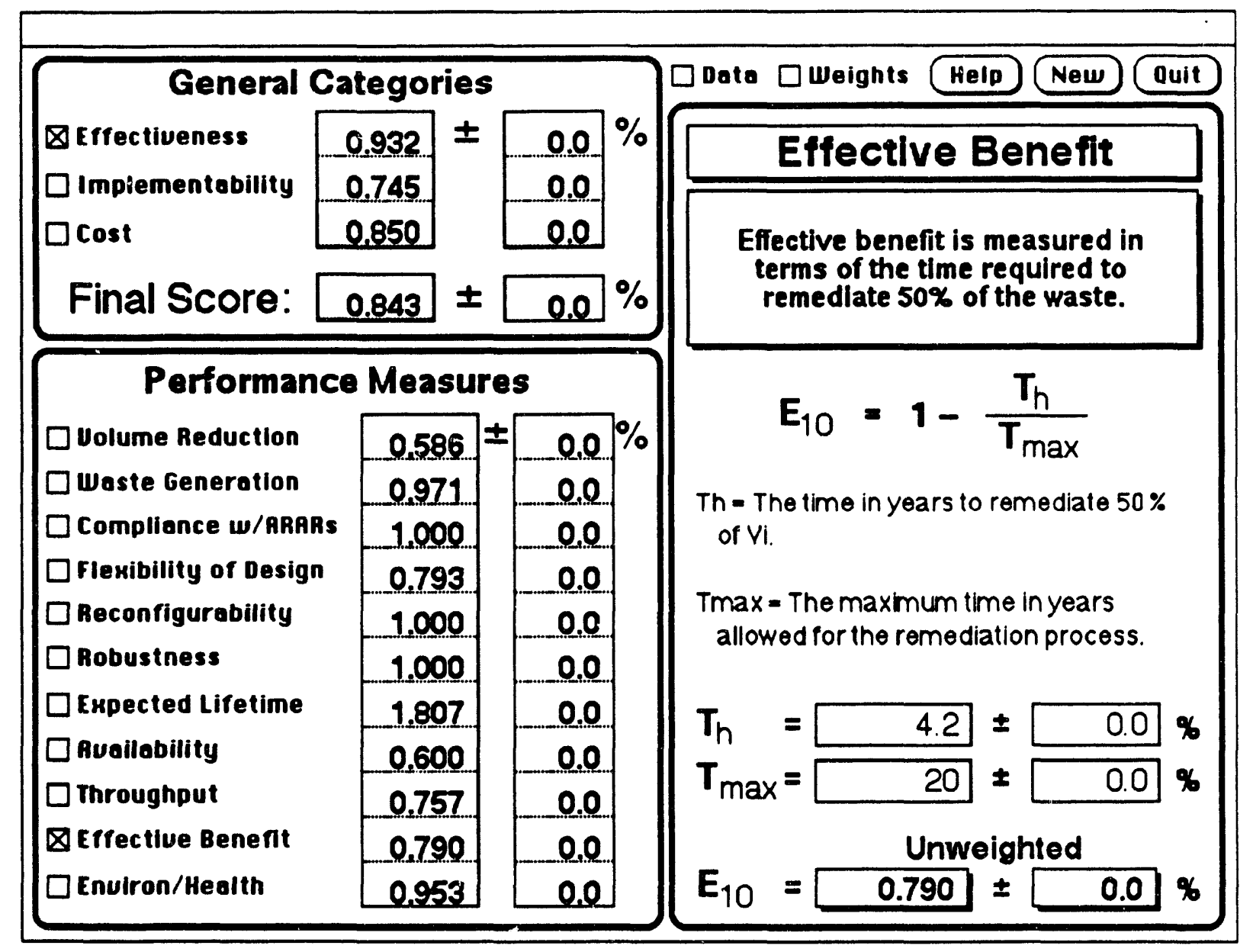




\begin{tabular}{|c|c|c|c|}
\hline \multicolumn{3}{|c|}{ General Categories } & $\square$ Doto $\square$ weights Help New Ouit \\
\hline \multirow{4}{*}{$\begin{array}{l}\otimes \text { Effectiveness } \\
\square \text { Implementobility } \\
\square \text { cost } \\
\text { Final Score: }\end{array}$} & \multirow{3}{*}{$\begin{array}{l}0.932 \\
0.745 \\
0.850 \\
\end{array}$} & \multirow{3}{*}{$\begin{array}{l}0.0 \\
0.0 \\
0.0\end{array}$} & Environ/Health \\
\hline & & & \multirow{3}{*}{$\begin{array}{l}\text { This score assesses the ability of } \\
\text { the system to maintaln a sare } \\
\text { environment. }\end{array}$} \\
\hline & & & \\
\hline & $0.843 \pm$ & $0.0 \%$ & \\
\hline \multicolumn{3}{|c|}{ Performance Measures } & \multirow{3}{*}{$E_{11}=1-$} \\
\hline \multirow{4}{*}{\begin{tabular}{|l|}
$\square$ Volume Reduction \\
$\square$ Woste Generotion \\
$\square$ Complionce w/rRARs \\
$\square$ Flesibility of Design
\end{tabular}} & 0.586 & $\pm 0.0 \%$ & \\
\hline & 0.971 & 0.0 & \\
\hline & 1.000 & 0.0 & \multirow{2}{*}{$\begin{array}{l}\text { Cis = The total capital expenses which are } \\
\text { "important-to-safety" items ( } \mathbf{S k} \text { ). }\end{array}$} \\
\hline & 0.793 & 0.0 & \\
\hline \multirow{2}{*}{$\begin{array}{l}\square \text { Reconfigurability } \\
\square \text { Robustness }\end{array}$} & 1.000 & 0.0 & \multirow[t]{2}{*}{$c m=$ The total life-cycle $\operatorname{cost}($ (Sk). } \\
\hline & 1.000 & 0.0 & \\
\hline \multirow{4}{*}{$\begin{array}{l}\square \text { Expected Lifetime } \\
\square \text { Auailability } \\
\square \text { Throughput } \\
\square \text { Efrectlue Benefit } \\
\text { E Environ/Health }\end{array}$} & 1.807 & 0.0 & $23900 \pm 1$ \\
\hline & $\begin{array}{l}0.600 \\
0.757\end{array}$ & $\begin{array}{l}0.0 \\
0.0\end{array}$ & $\mathbf{C}_{m}=511000 \pm$ \\
\hline & 0.790 & 0.0 & Unweighted \\
\hline & 0.953 & 0.0 & $0.953 \pm[$ \\
\hline
\end{tabular}




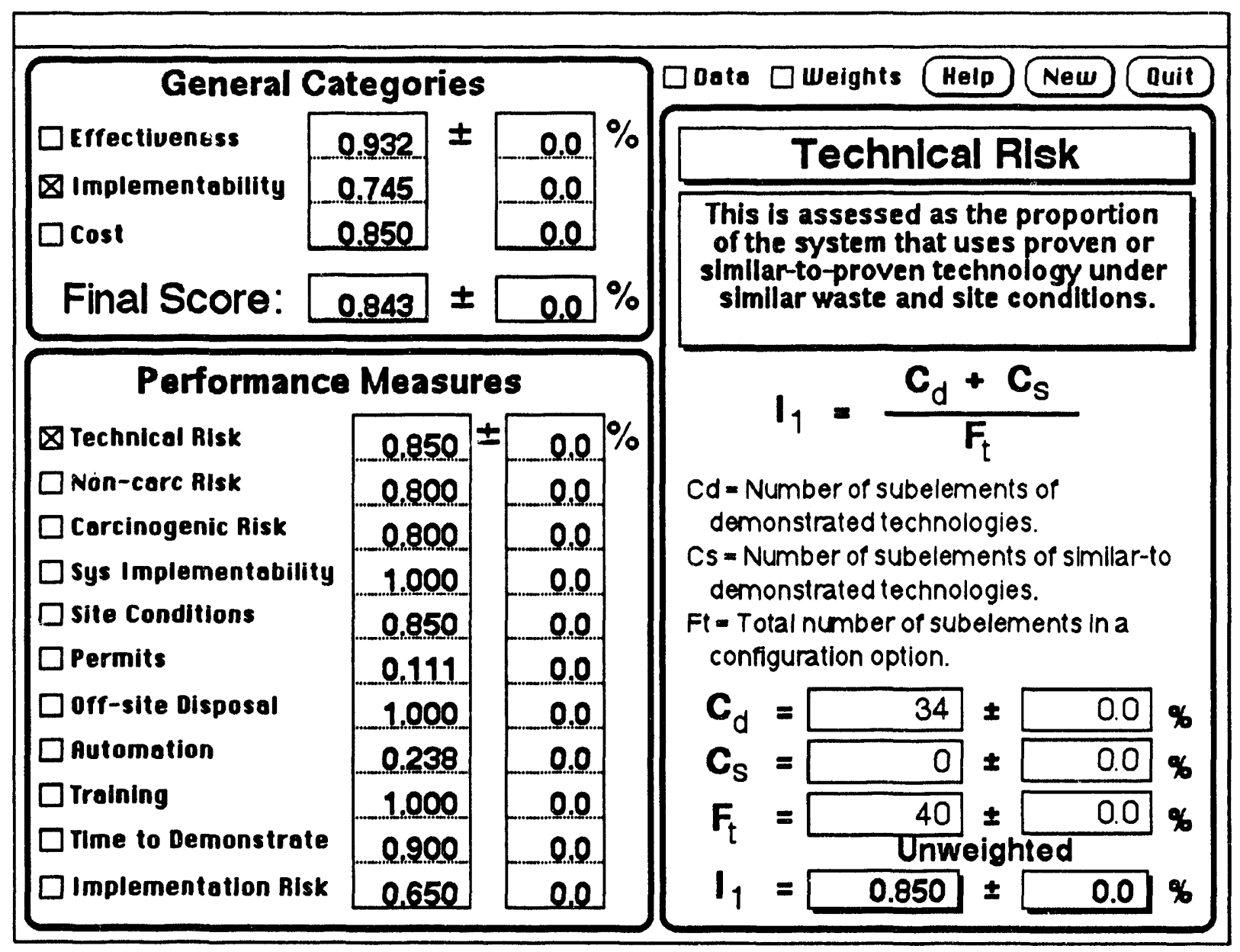




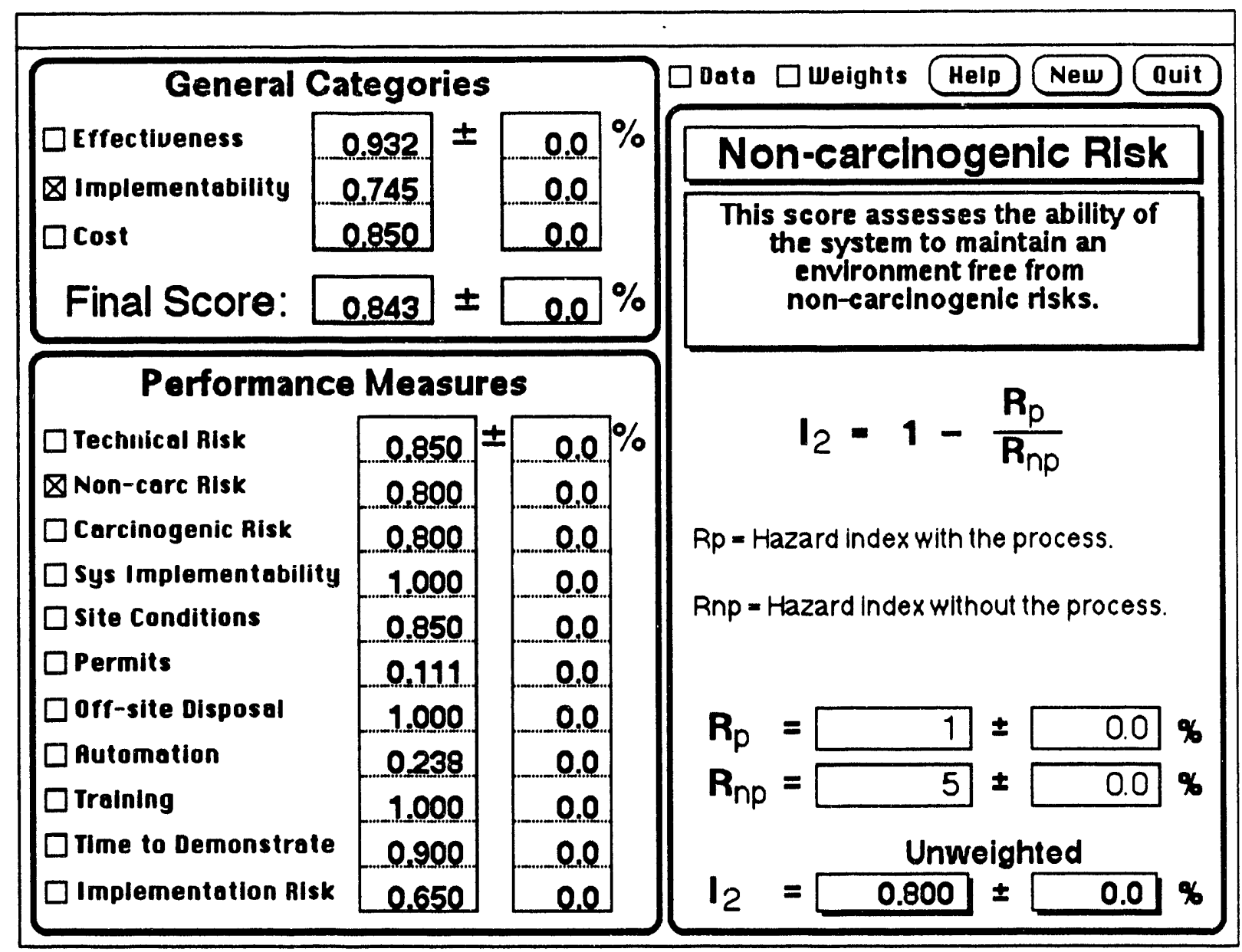




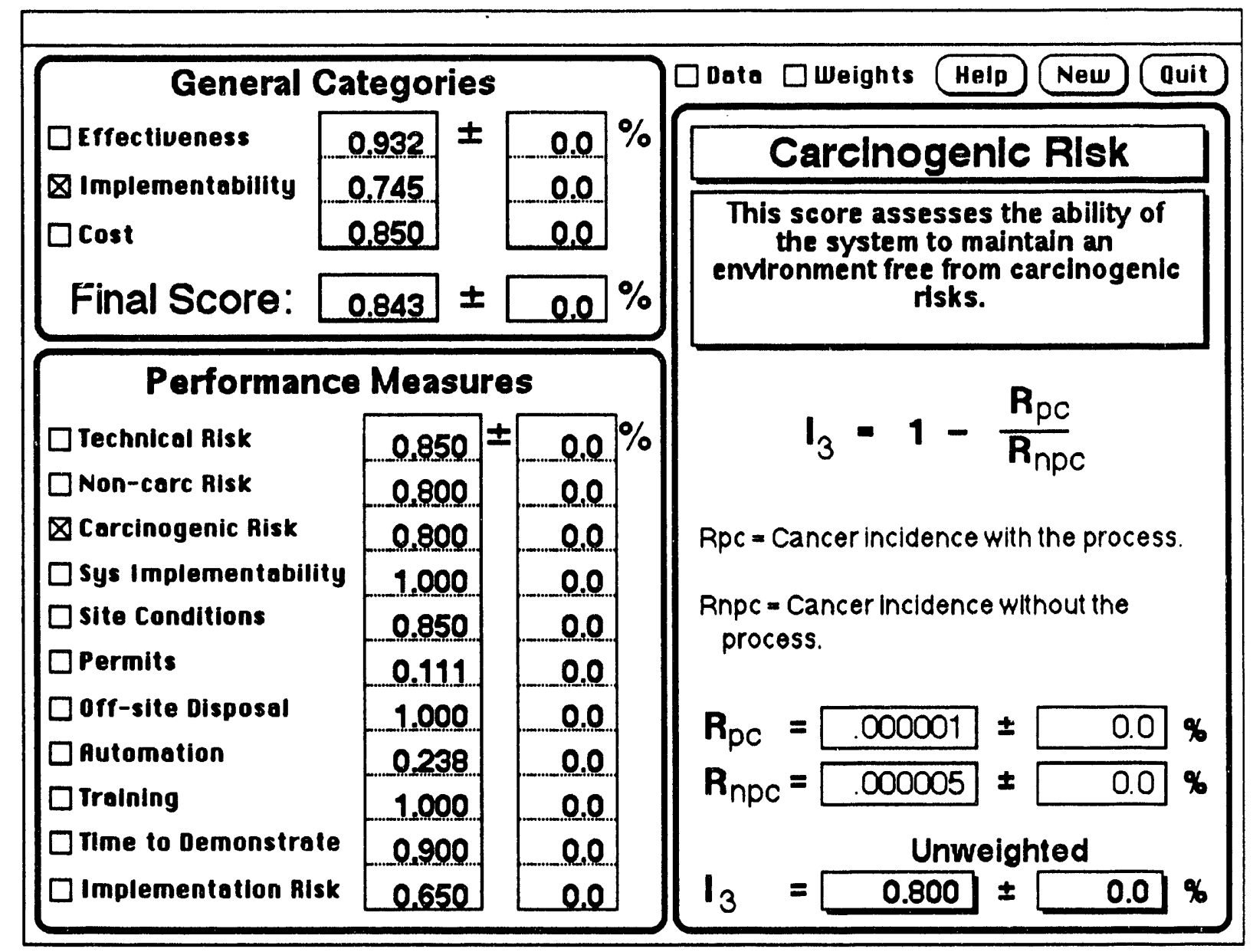




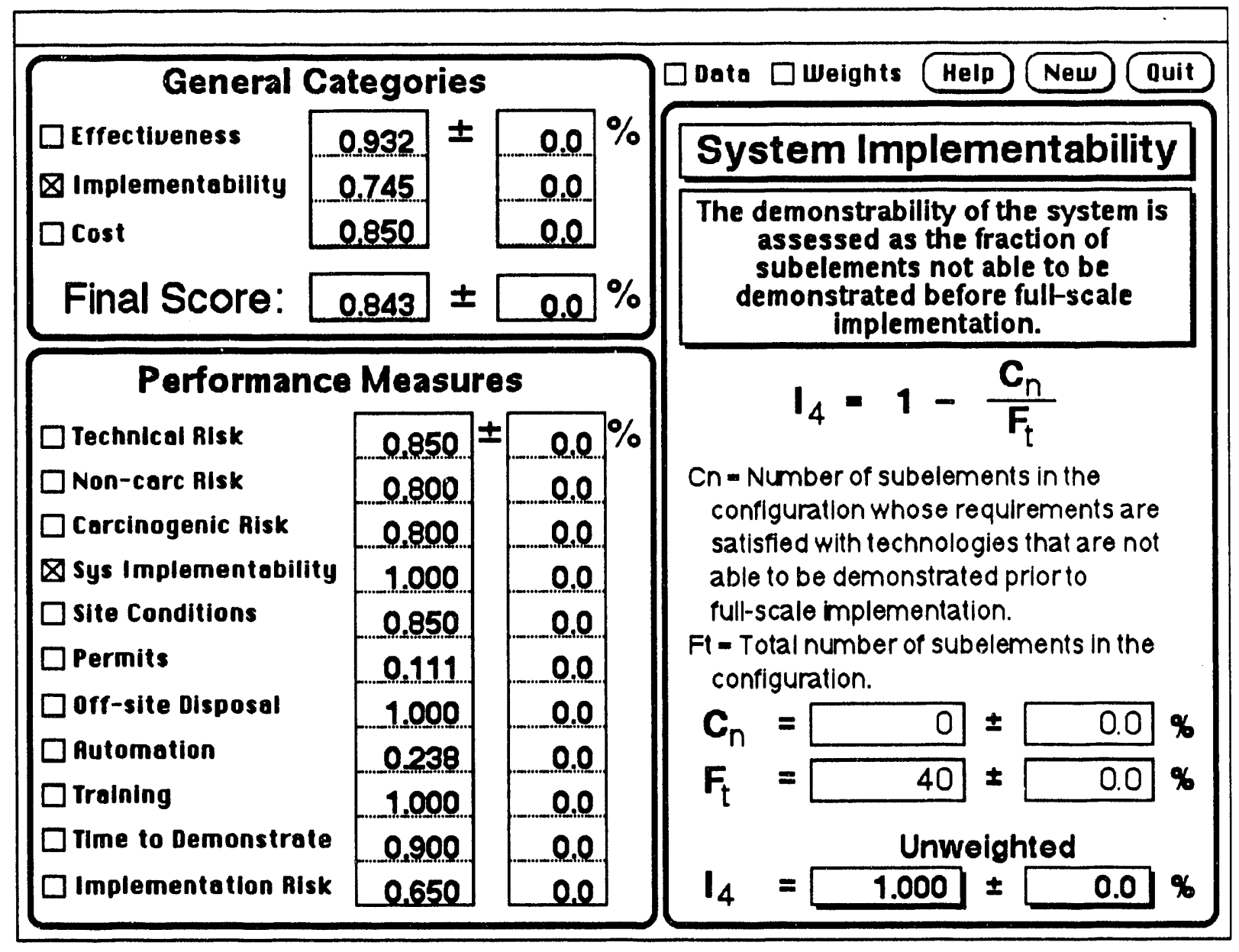




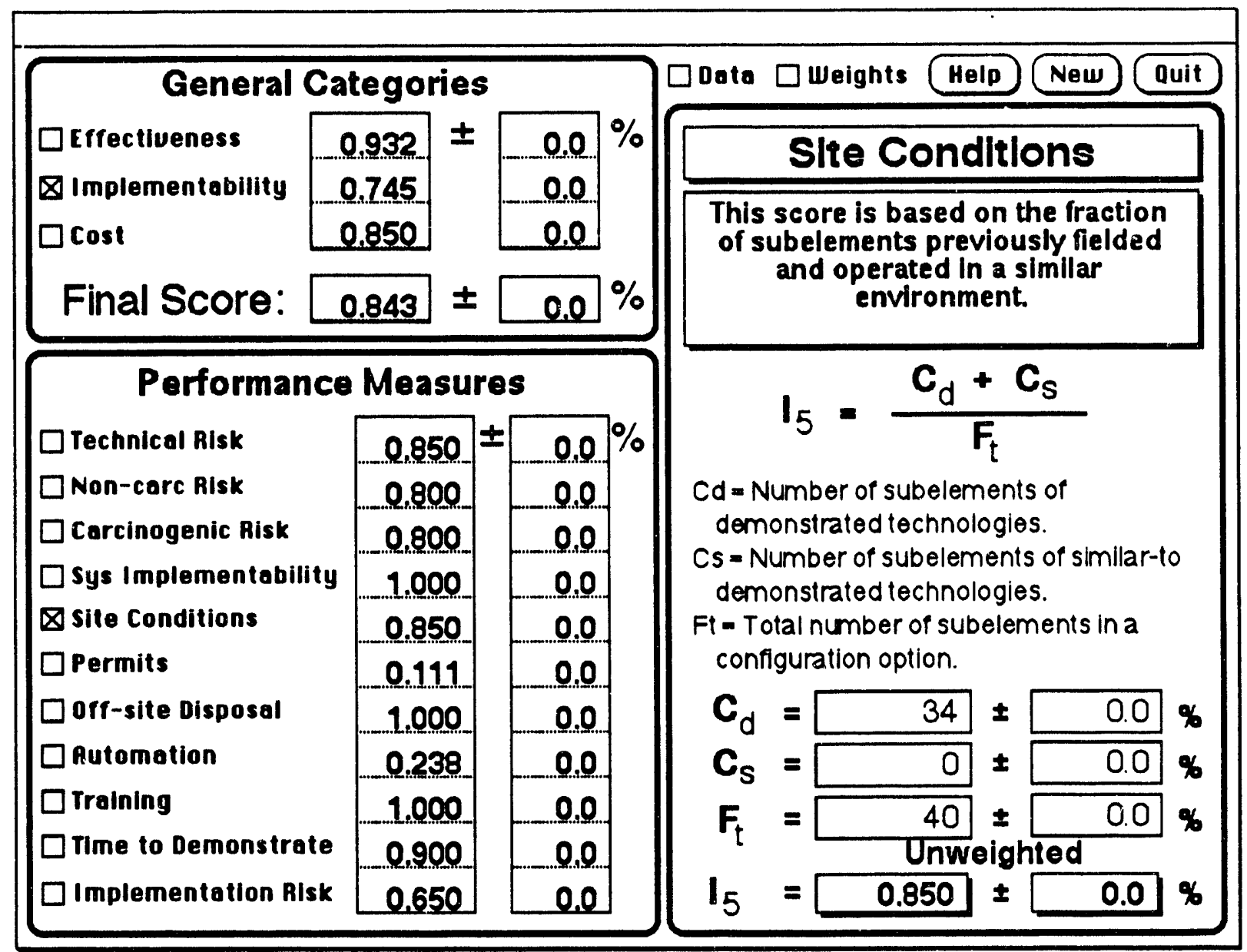




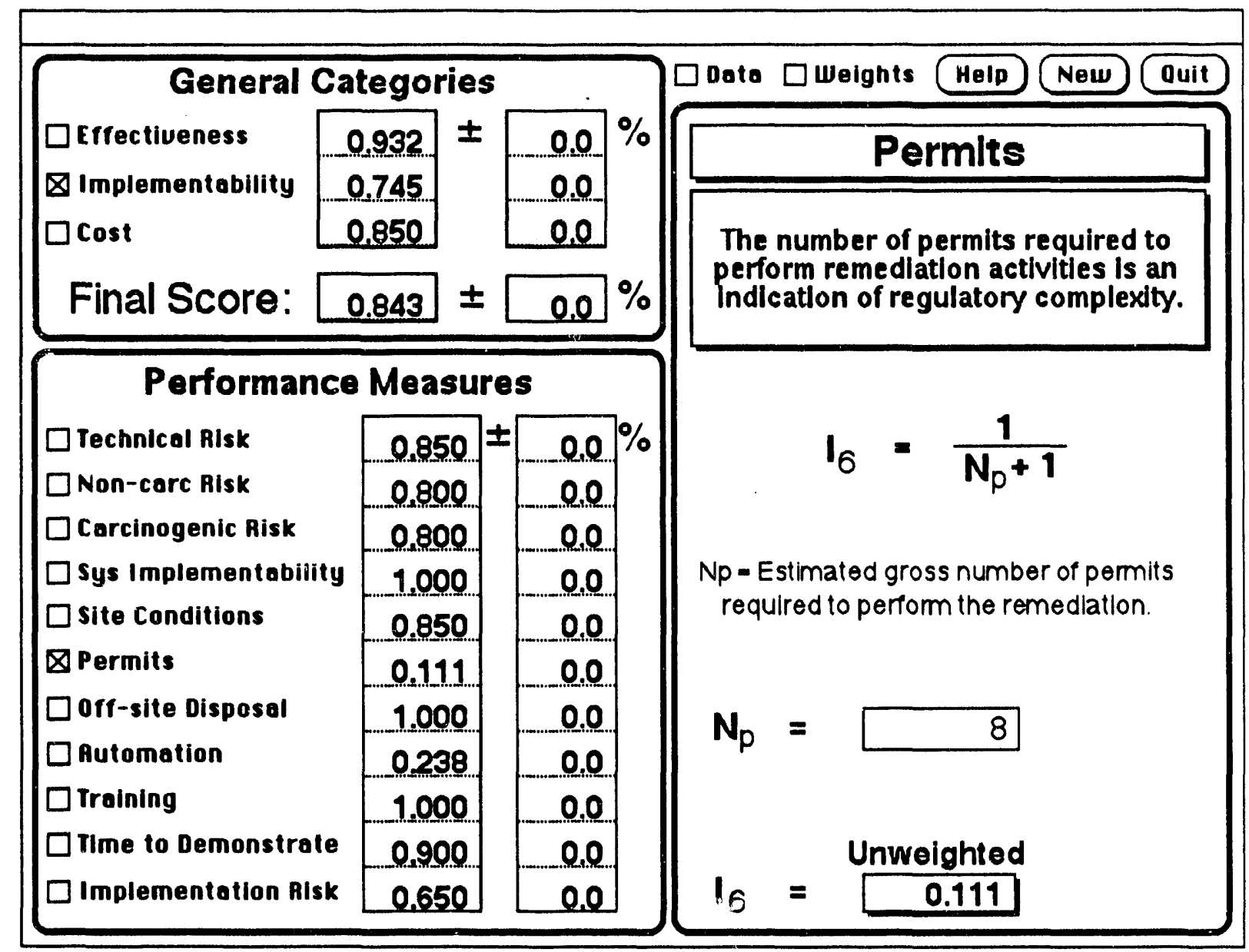




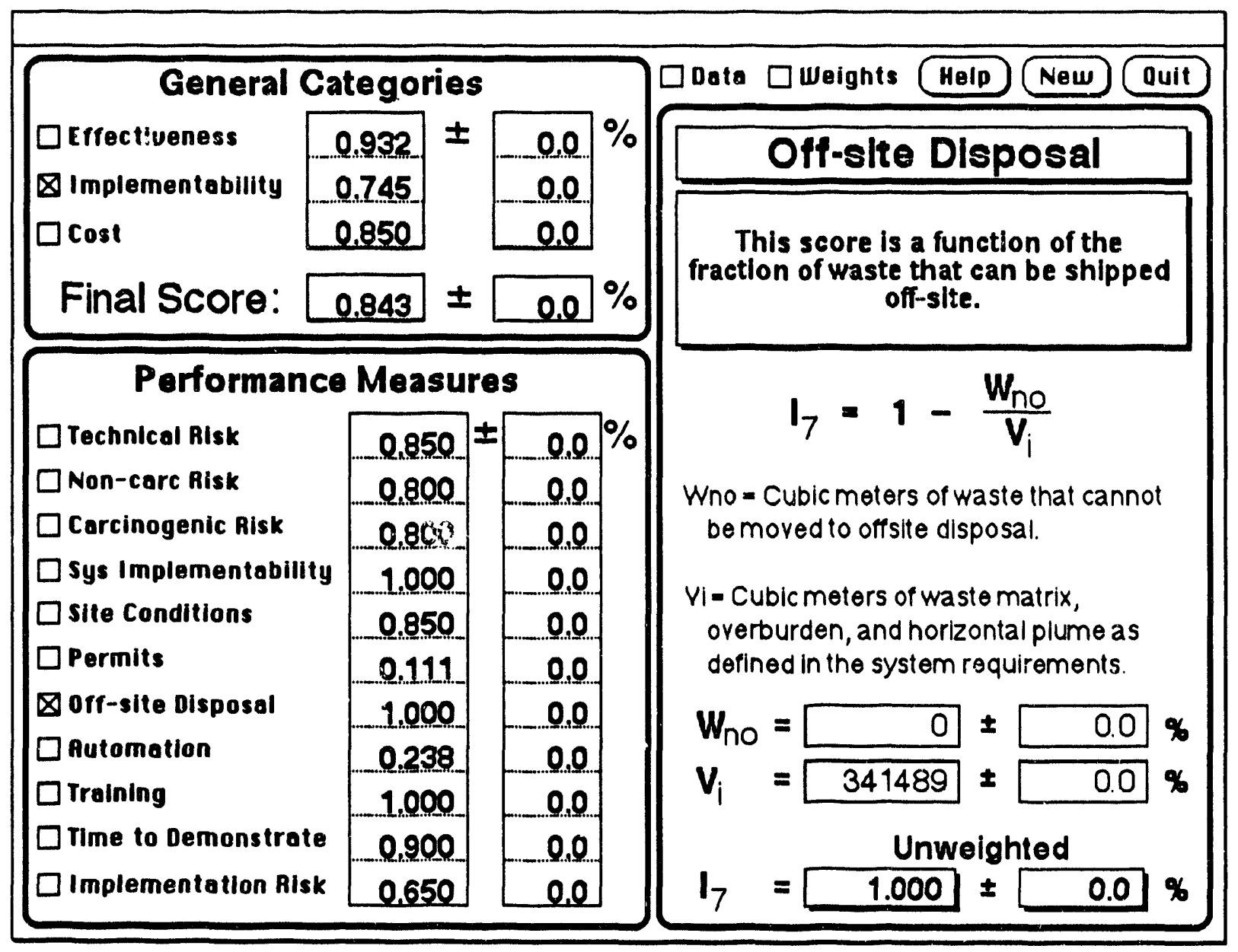




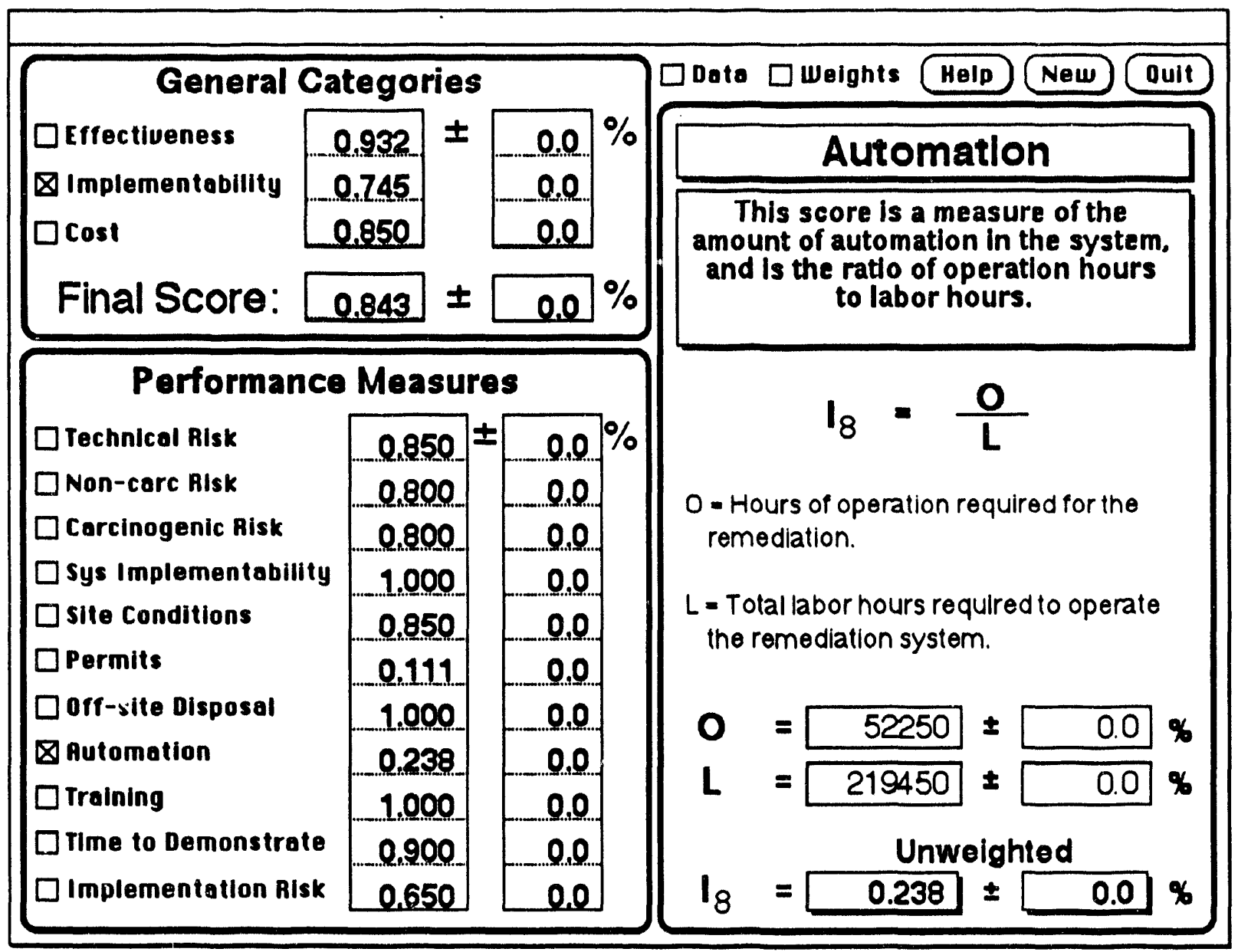




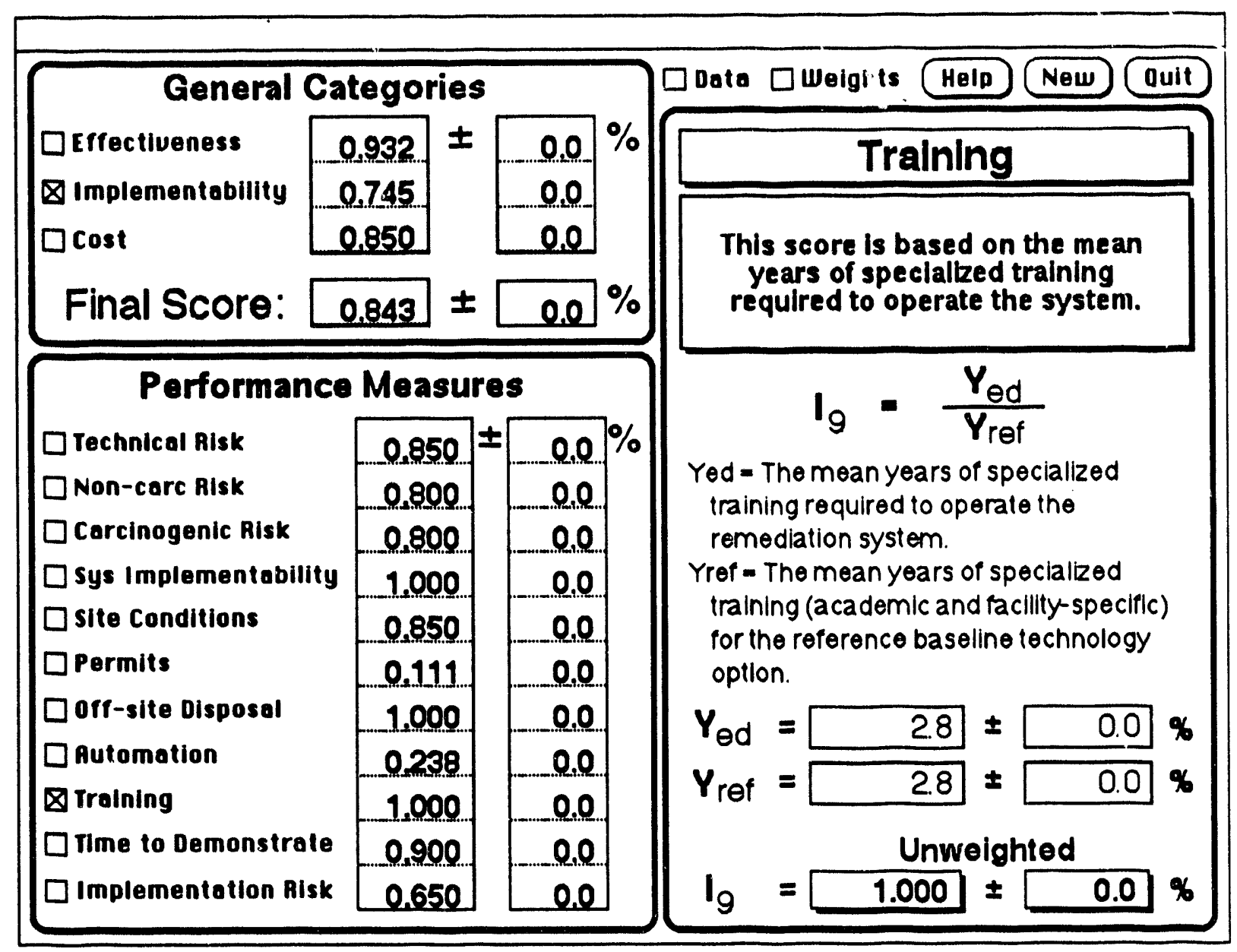




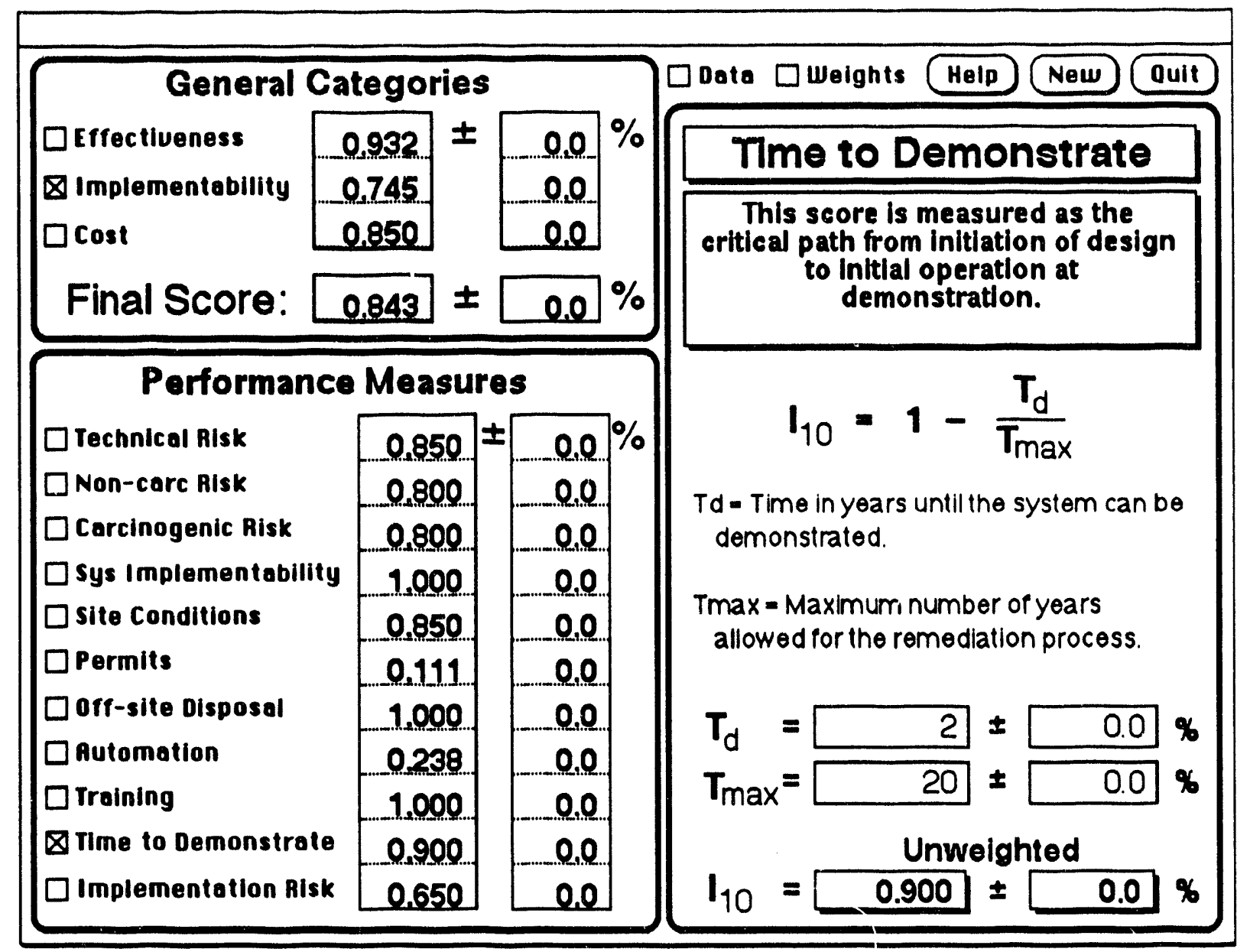




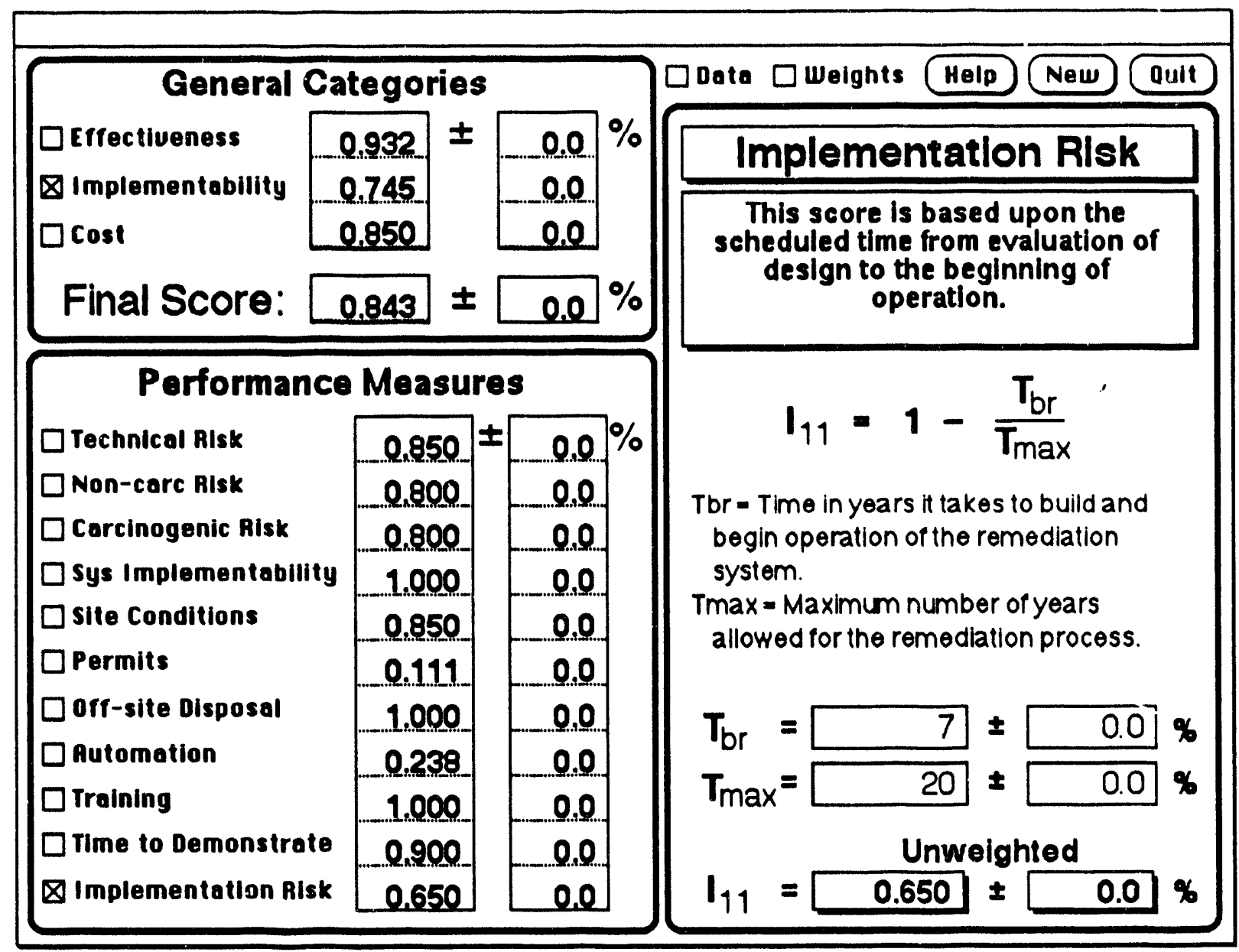




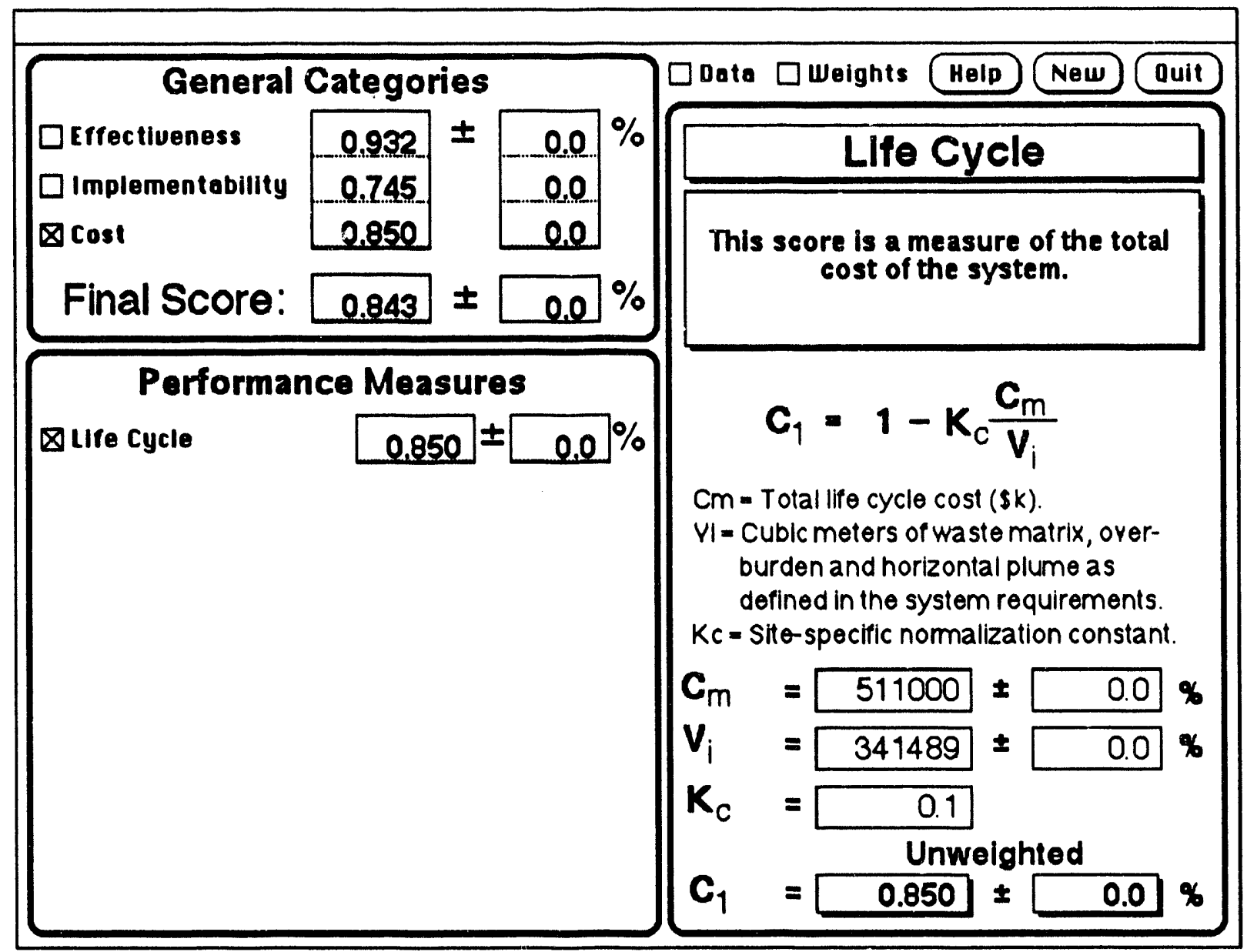




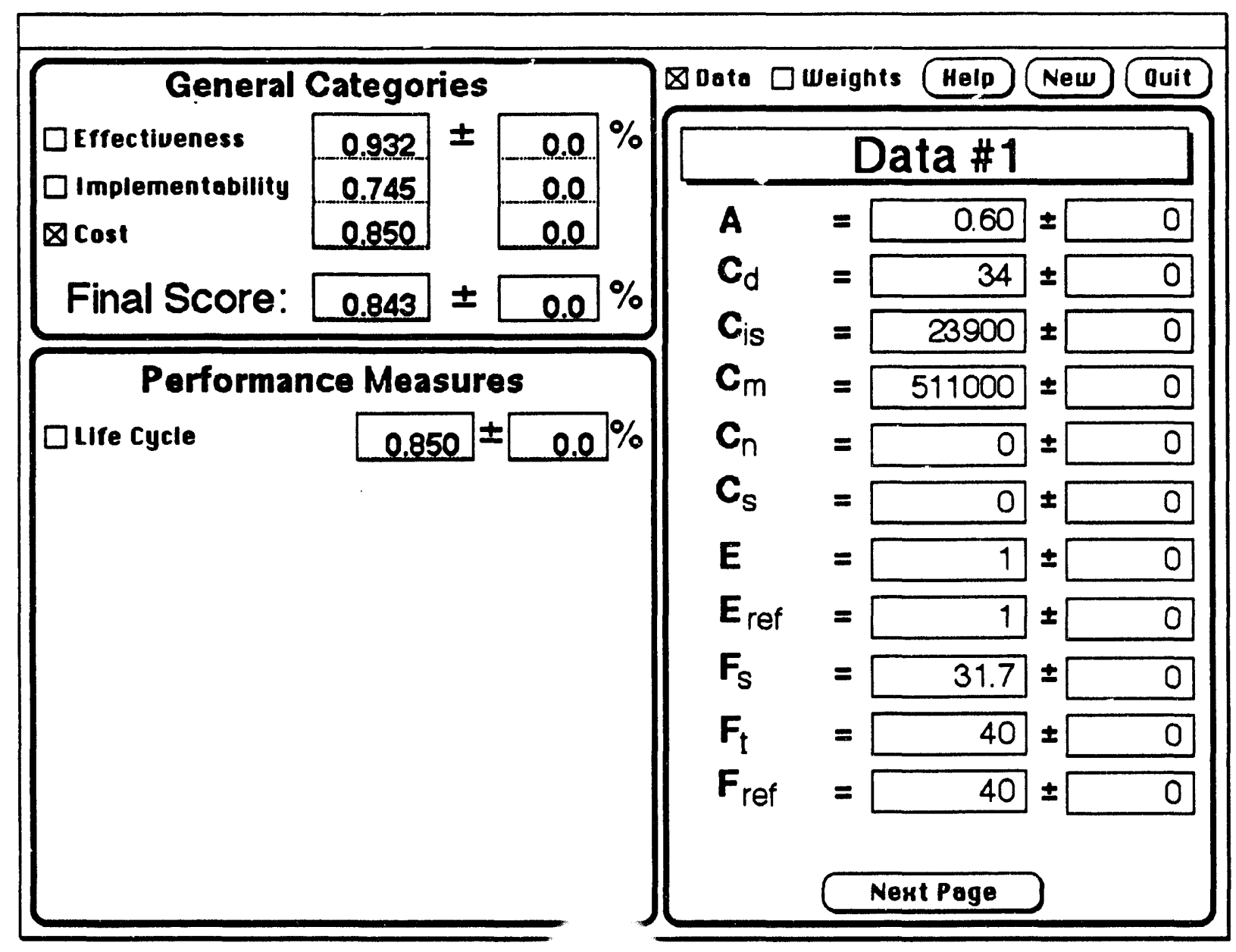




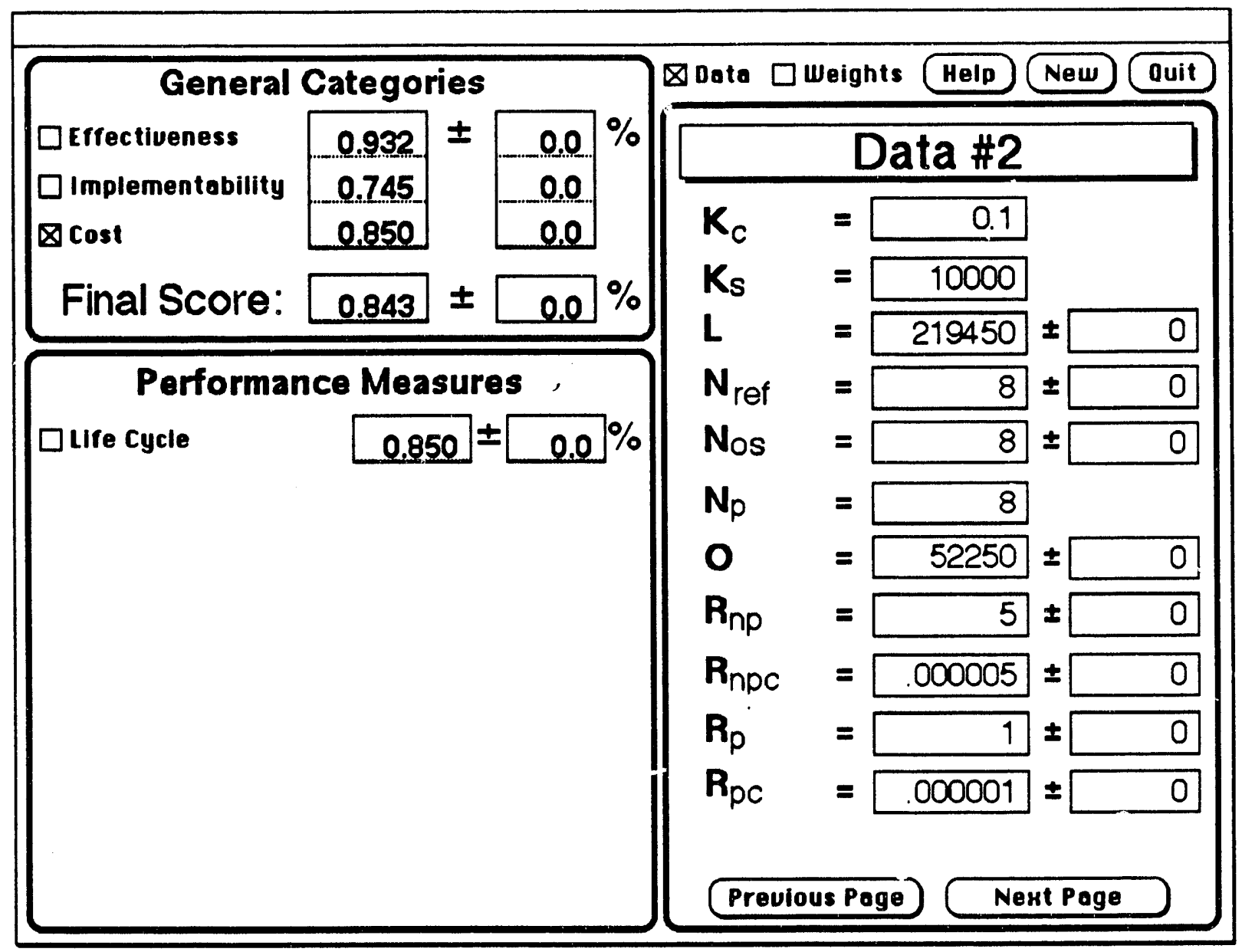




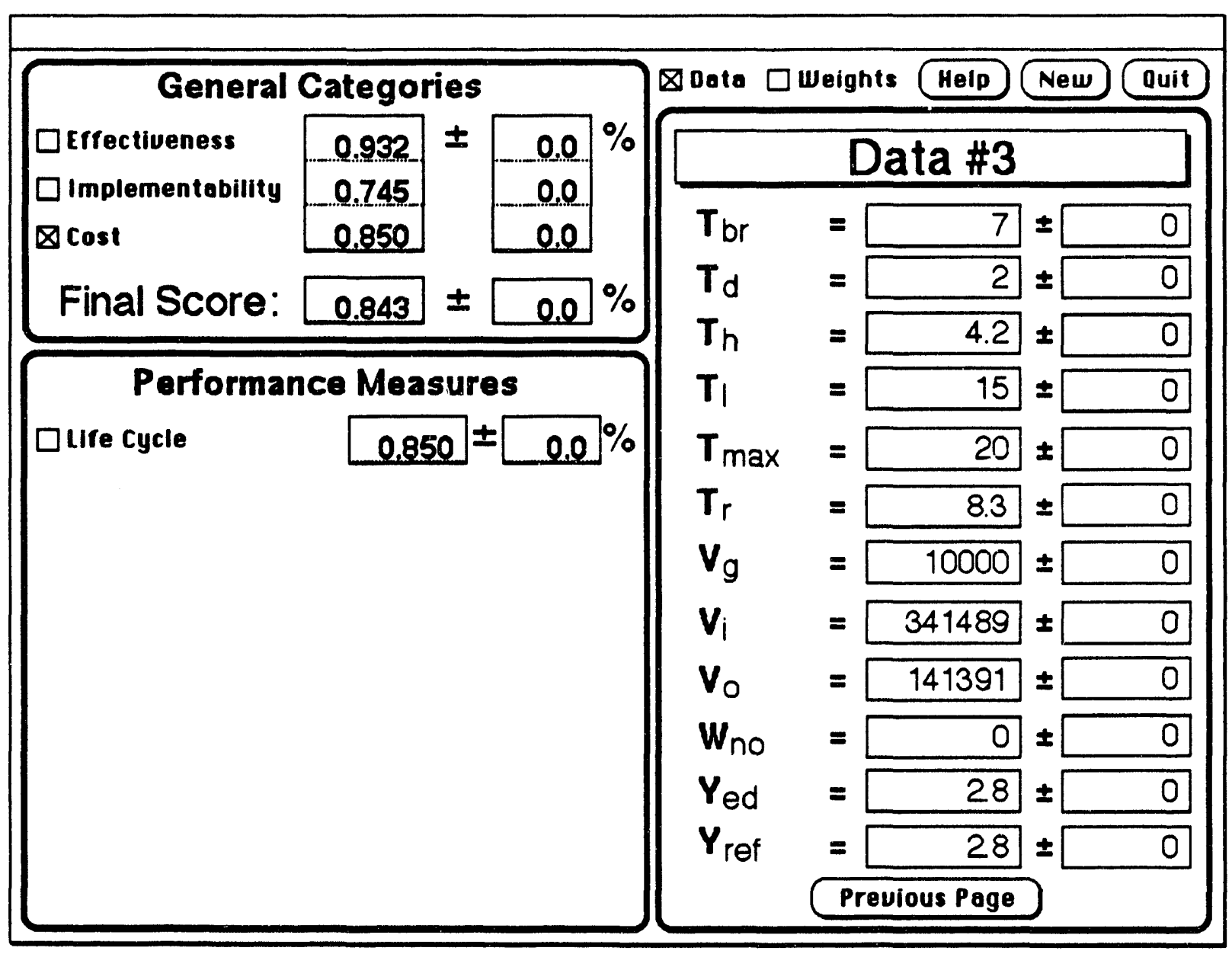




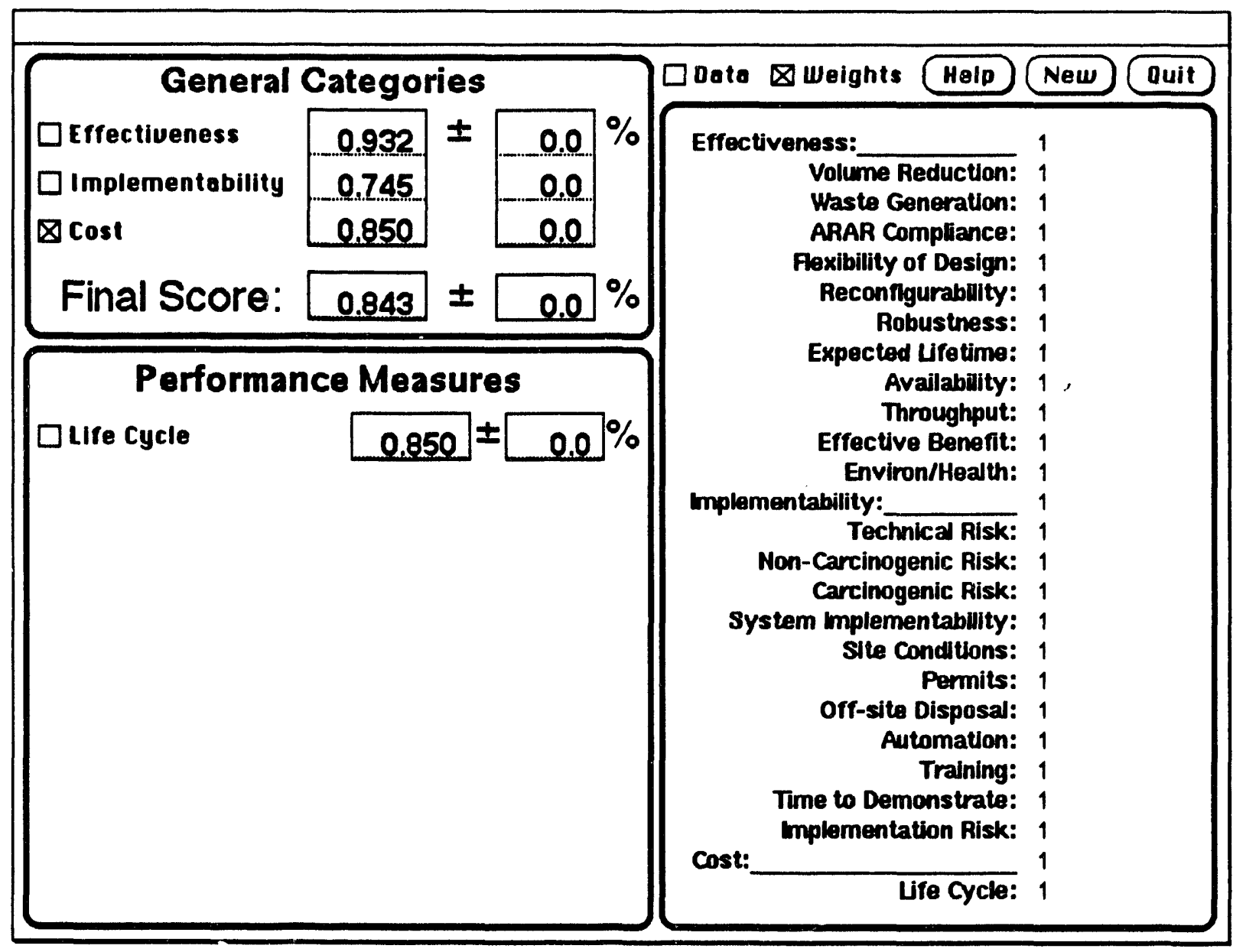




\section{REFERENCES}

1. J. G. Richardson et al., INEL Operable Unit 7.1.3 RetrievallEx Situ Thermal Treatment Configuration Options, EGG-WTD-1(121)4, July 1992.

2. D. A. Arrenholz and J. L. Knight, A Brief Analysis and Description of Transuranic Wastes in the Subsurface Disposal Area of the Radioactive Waste Management Complex at INEL, EGG-WTD9438, Rev. 1, August 1991.

3. University of California Research Center, Design and Evaluation Guidelines for Department of Energy Facilities Subjected to Natural Phenomenon Hazard UCRL-15910. October 1989.

4. U. S. Department ol Energy, "General Design Criteria," DOE Order 64.30).1A, April 1989.

5. U. S. Department ol Energy Idaho Field Olfïc, DOE-ID Architectural Engineering Standards, September 1991.

6. U. S. Department of Energy Idaho Field Office, Operational Safety Design Criteria Manual, ID-12044, April 1985.

7. M. C. O'Brien, Performance-based Technology Selection Description Report, EGG-WTD-9989, May 1992.

8. U. S. Department of Energy, "Radiation Protection for Occupational Workers," DOE Order 5480.11.

9. U. S. Department of Energy Idaho Field Oflice, INEL Transuranic Waste Acceptance Criteria, DOE/ID-10074, Rev. 5, October 1992.

10. U. S. Department of Energy Idaho Field Office, INEL Low-level Radioactive Waste Acceptance Criteria, DOE/ID 10112, Rev. 4, Outober 1991.

11. EG\&G Idaho, Inc., "Transler, Storage, Handling, and Tracking of Waste, Program Directive, RWMC PD-RS-1.8, April 9. 1992.

12. EG\&G Idaho, Inc., Hazardous Material Transportation Manual.

13. U. S. Department of Energy, "Salety of Nuclear Facilities," DOE Order 548().5.

14. U. S. Department of Energy Idaho Field Olfice, "Salicty of Nuclear Facilities," DOE-ID Order 5480.5A.

15. B. D. Ravio, Functional and Operational Requirements for Waste Technology Division Thermal Processing Technologies-Pilot Test Demonstration. EGG F/OR 157. Project No. 015525, September 26, 1991.

16. EG\&G Idaho, Inc., Technology Design File, "BWID System Requirements," SA-2.(). 
17. G. A. Reimann, T. L. Grandy. T. L. Eddy, and G. L. Anderson, Summany of INEL Research on the IEB Waste Form. EGG-WTD-1()(156, September 1991.

18. A. D. Donaldson, R. J. Carpenedo, and G. L. Anderson, Melter Derelopmeme Needs Assessment, EGG-WTD-9911, January 1992.

19. P. C. Kong, T. L. Eddy, B. D. Raivo, and G. L. Anderson, Mixed Waste Materials Processing via Thermal Processing Technologies, EGG-WTD-10058, September 1991.

20. B. A. Detering and J. A. Batdorf, Plasma Tieatment of INEL Soil Contaminated with Heavy Metals, EGG-WTD-9925, January 1992.

21. EG\&G Idaho, Inc., "Trade-otl' Study Perlormance Mcasures," Technology Design File SA-4.103.

22. U. S. Department of Energy, Idaho National Enginecring Laboralong Installation Roadmap, DOE/ID-104(15, Septembur 1992.

23. T. H. Smith et al., A Preliminany Evaluation of Alternatives for Treament of INEL Low-Level Warte and Low Level Maxed Waste. EGG-WMO-11)321. June 1992.

24. IT Corporation, Idaho Waste Processing Facility Envirommental Compliance Planning Summary, September 19, 1991. 


\begin{abstract}
Appendix A
INEL OU 7-13 Waste Pit and Trench Characteristics Tables
\end{abstract}


Table A-1. Excavation details for selected trenches at the SDA.

\begin{tabular}{|c|c|c|c|c|c|c|c|c|}
\hline $\begin{array}{c}\text { Trench } \\
\text { no. }\end{array}$ & $\begin{array}{c}\text { Mean } \\
\text { surface } \\
\text { elevation } \\
\text { (ft) }\end{array}$ & $\begin{array}{c}\text { Mean } \\
\text { basalt } \\
\text { surface } \\
\text { elevation } \\
\text { (fi) }\end{array}$ & $\begin{array}{c}\text { Average } \\
\text { estimated } \\
\text { overburden } \\
\text { (fi) }\end{array}$ & $\begin{array}{c}\text { Estimated } \\
\text { excavated } \\
\text { depth }^{\mathrm{a}} \\
\text { (ft) }\end{array}$ & $\begin{array}{c}\text { Estimated } \\
\text { width } \\
\text { (ft) }\end{array}$ & $\begin{array}{c}\text { Estimated } \\
\text { length } \\
\text { (ft) }\end{array}$ & $\begin{array}{c}\text { Surface } \\
\text { area } \\
\left(\mathrm{ft}^{2}\right) \\
\end{array}$ & $\begin{array}{c}\text { Excavated } \\
\text { volume } \\
\left(\mathrm{ft}^{3}\right) \\
\end{array}$ \\
\hline 1 & $5,012.9$ & 4997 & 3.8 & 10.1 & 7 & 1149 & 8043 & 81,243 \\
\hline 2 & $5,012.1$ & 4993 & 4.0 & 13.1 & 6 & 1106 & 6636 & 86,932 \\
\hline 3 & $5,012.6$ & 4993 & 4.0 & 13.6 & 6 & 1111 & 6666 & 90,658 \\
\hline 4 & $5,013.0$ & 4993 & 4.0 & 14.0 & 6 & 1117 & 6702 & 93,828 \\
\hline 5 & $5,013.6$ & 4997 & 3.8 & 14.6 & 6.6 & 1166 & 7696 & 112,362 \\
\hline 6 & $5,012.7$ & 4993 & 4.0 & 13.7 & 6 & 1119 & 6714 & 91,982 \\
\hline 7 & 5.014 .2 & 4997 & 3.8 & 11.4 & 6.6 & 1161 & 7656 & 87,278 \\
\hline$\therefore$ & $5,013.1$ & 4993 & 4.0 & 14.1 & 6 & 1120 & 6720 & 97,752 \\
\hline 9 & $5,013.8$ & 4997 & 3.8 & 11.0 & 6.6 & 1152 & 7603 & $83,63.3$ \\
\hline 10 & $5,012.6$ & 4993 & 4.0 & 13.6 & 6 & 1121 & 6726 & 91,474 \\
\hline
\end{tabular}

a. The excavated deptin was calculated by taking the difference between the surface and hasalt elevations. From this value, the estimated overburden was subtracted out. Finally, an additional 2 if $(1 \mathrm{ft}$ for basalt overburden and 1 fi for depth of buried waste from original surlace elevation) were subtriticd out. 
Table A-2. Various physical characteristics of soil and sediment samples from the RWMC wells.

Depth interval

\begin{tabular}{llllllllll}
$\begin{array}{l}\text { Well } \\
\text { no. }\end{array}$ & Top & & Bottom & $\begin{array}{c}\text { Specific } \\
\text { gravity }\end{array}$ & $\begin{array}{c}\text { Bulk } \\
\text { density } \\
\left(\mathrm{g} / \mathrm{cm}^{3}\right)\end{array}$ & $\begin{array}{c}\text { Porosity } \\
\text { (percent) }\end{array}$ & $\begin{array}{c}\text { Moisture } \\
\text { content } \\
\text { (percent) }\end{array}$ & $\begin{array}{c}\text { Vertical } \\
\text { hydraulic } \\
\text { conduct } \\
\text { (m/day) }\end{array}$ \\
\hline 92 & $2 \mathrm{ft}$ & 6 in. & $5 \mathrm{ft}$ & & 2.65 & 1.87 & 34.3 & 12.9 & $5.5 \times 10^{-4}$ \\
94 & $6 \mathrm{ft}$ & 6 in. & $8 \mathrm{ft}$ & 3 in. & 2.67 & 2.02 & 30.5 & 16.4 & $2.7 \times 10^{-4}$ \\
95 & $10 \mathrm{ft}$ & & $12 \mathrm{ft}$ & 6 in. & 2.66 & 1.70 & 41.0 & 13.2 & $7.9 \times 10^{-3}$ \\
\hline
\end{tabular}

Table A-3. Properties of soil and sediment samples from the RWMC wells.

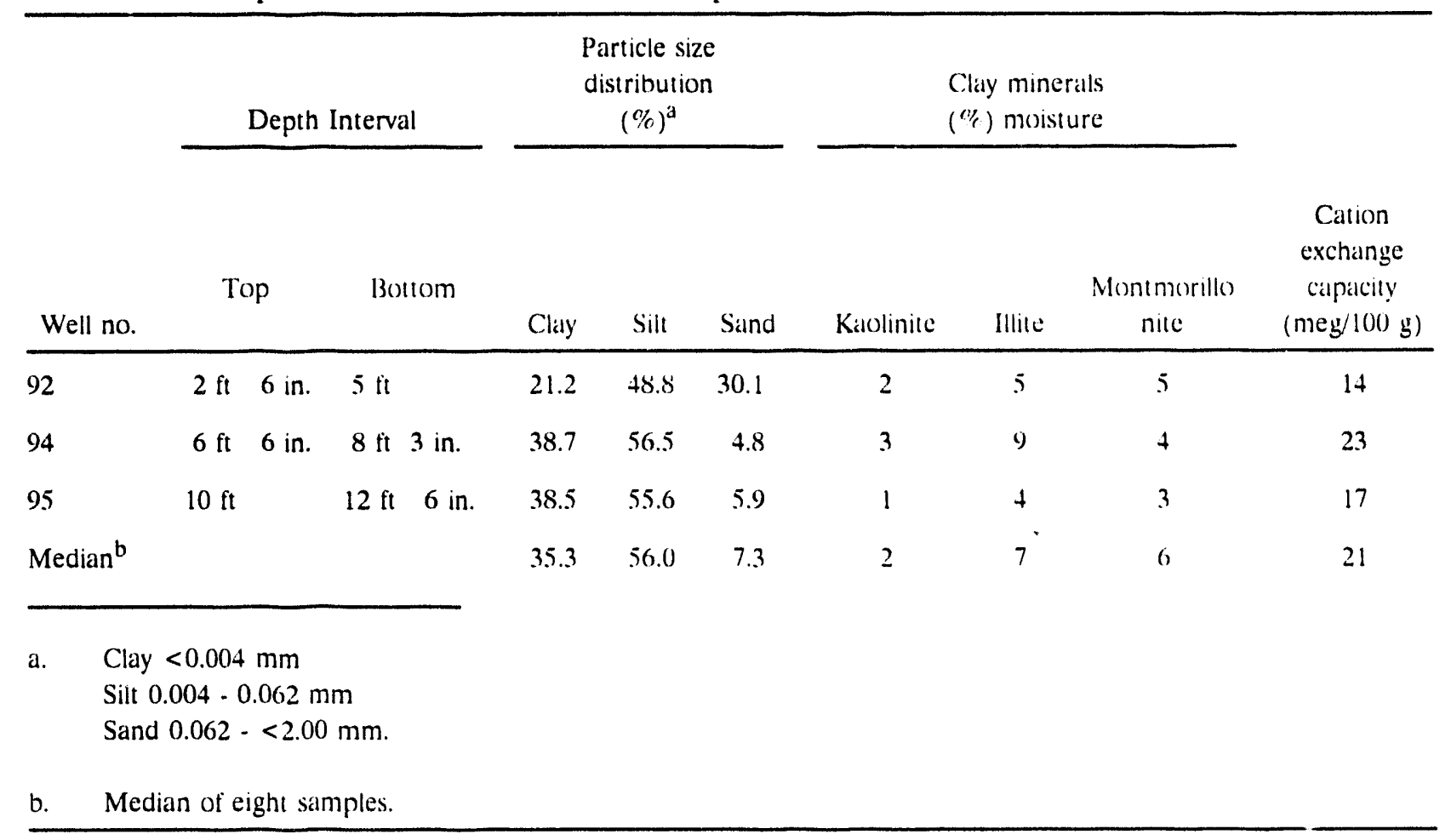


Table A-4. Particle size distribution for subpit samples (in percent of analyzed sample)."

\begin{tabular}{|c|c|c|c|c|c|c|c|}
\hline $\begin{array}{c}\text { Sample }^{b} \\
\text { no. }\end{array}$ & $\begin{array}{l}\text { Depth } \\
\text { (m) }\end{array}$ & $\begin{array}{l}\text { Clay } \\
<0.004 \\
\mathrm{~mm}\end{array}$ & $\begin{array}{l}\text { Silt } \\
0.004- \\
0.0625 \\
\mathrm{~mm}\end{array}$ & $\begin{array}{l}\text { Sand very } \\
\quad \text { fine } \\
0.0625 \\
0.125 \mathrm{~mm}\end{array}$ & $\begin{array}{l}\text { Sand } \\
\text { fine } \\
0.125 \\
0.25 \mathrm{~mm}\end{array}$ & $\begin{array}{l}\text { Sand } \\
\text { medium } \\
\text { (0.25-(1).5 mm }\end{array}$ & $\begin{array}{l}\text { Sand } \\
\text { coarse } \\
0.5-1 \mathrm{~mm}\end{array}$ \\
\hline EWR-1-4 & 0.91 & 53.3 & 38.5 & 4.8 & 2.3 & 0.9 & 0.1 \\
\hline EWR-1-3 & 1.22 & 41.0 & 30.1 & 11.0 & 17.7 & 0.2 & 0 \\
\hline EWR-1-2 & 1.52 & 54.7 & 40.1 & 4.1 & 0.7 & 0.2 & 0.1 \\
\hline EWR-1-1 & 1.83 & 23.5 & 69.8 & 6.0 & 0.6 & 0 & 0.1 \\
\hline \multicolumn{8}{|c|}{$\begin{array}{l}\text { a. Analyzed by the USGS Hydrologic Laboratory, Denver, Colorado. } \\
\text { b. All samples from surficial deposits. } \\
\text { c. No particles coarser than } 1 \mathrm{~mm} \text { observed. }\end{array}$} \\
\hline
\end{tabular}

Table A-5. Mineralogy for subpit samples (in percent of analyzed sample). ${ }^{a}$

\begin{tabular}{lcccccccc}
\hline $\begin{array}{c}\text { Sample } \\
\text { no. }\end{array}$ & $\begin{array}{c}\text { Depth } \\
(\mathrm{m})\end{array}$ & Quartz & $\begin{array}{c}\text { Potassium } \\
\text { feldspar }\end{array}$ & Plagioclase & Calcite & $\begin{array}{c}\text { Pryoxenc } \\
\text { dioxide }\end{array}$ & $\begin{array}{c}\text { Clay } \\
\text { minerals }\end{array}$ & $\begin{array}{c}\text { Total } \\
\text { percent }\end{array}$ \\
\hline EWR-1-4 & 0.91 & 27 & $\leq 5$ & 11 & 1 & 4 & 70 & $113+{ }^{\mathrm{c}}$ \\
EWR-1-3 & 1.22 & 29 & $\leq 6$ & 10 & 0 & 9 & 55 & $10.3+$ \\
EWR-1-2 & 1.52 & 15 & $\leq 3$ & 6 & 41 & $\leq 9$ & 25 & $87+$ \\
EWR-1-1 & 1.83 & 29 & 5 & 12 & 13 & $\leq 9$ & 40 & $99+$ \\
& \\
a. Analyzed by the USGS Hydrologic Laboratory, Denver, Colorado. \\
b. All samples from surficial deposits. \\
c. Due to high percentage of clay minerals.
\end{tabular}


Table A-6. Clay mineralogy of selected surficial sediment samples (in percent of total clay minerals/percent of original bulk samples)."

\begin{tabular}{|c|c|c|c|c|c|c|c|c|}
\hline Sample & $\begin{array}{l}\text { Depth } \\
\text { (m) }\end{array}$ & Chlorite & Illite & $\begin{array}{c}\text { Mixed layer } \\
\text { clays } \\
\text { (illite/smectite) }\end{array}$ & Smectite & Katolinite & $\begin{array}{l}\text { Cation } \\
\text { exchange } \\
\text { capacity" }\end{array}$ & $\begin{array}{c}\text { Carbonate content } \\
\left(\mathrm{CaCO}_{3}\right) \\
\text { percent }\end{array}$ \\
\hline EWR-1-4 & 0.91 & $0 / 03$ & $6 / 25$ & $45 / 32$ & $13 / 9$ & $6 / 4$ & 27 & 0 \\
\hline EWR-1-3 & 1.22 & $0 / 03$ & $0 / 16$ & $48 / 26$ & $15 / 9$ & $6 / 3$ & 27 & 2.3 \\
\hline EWR-1-2 & 1.52 & $0 / 03$ & $6 / 9$ & $31 / 8$ & $24 / 6$ & $9 / 2$ & 11 & 36.1 \\
\hline EWR-1-1 & 1.83 & $0 / 03$ & $2 / 12$ & $30 / 12$ & $26 / 10$ & $12 / 5$ & 11 & 10.8 \\
\hline
\end{tabular}



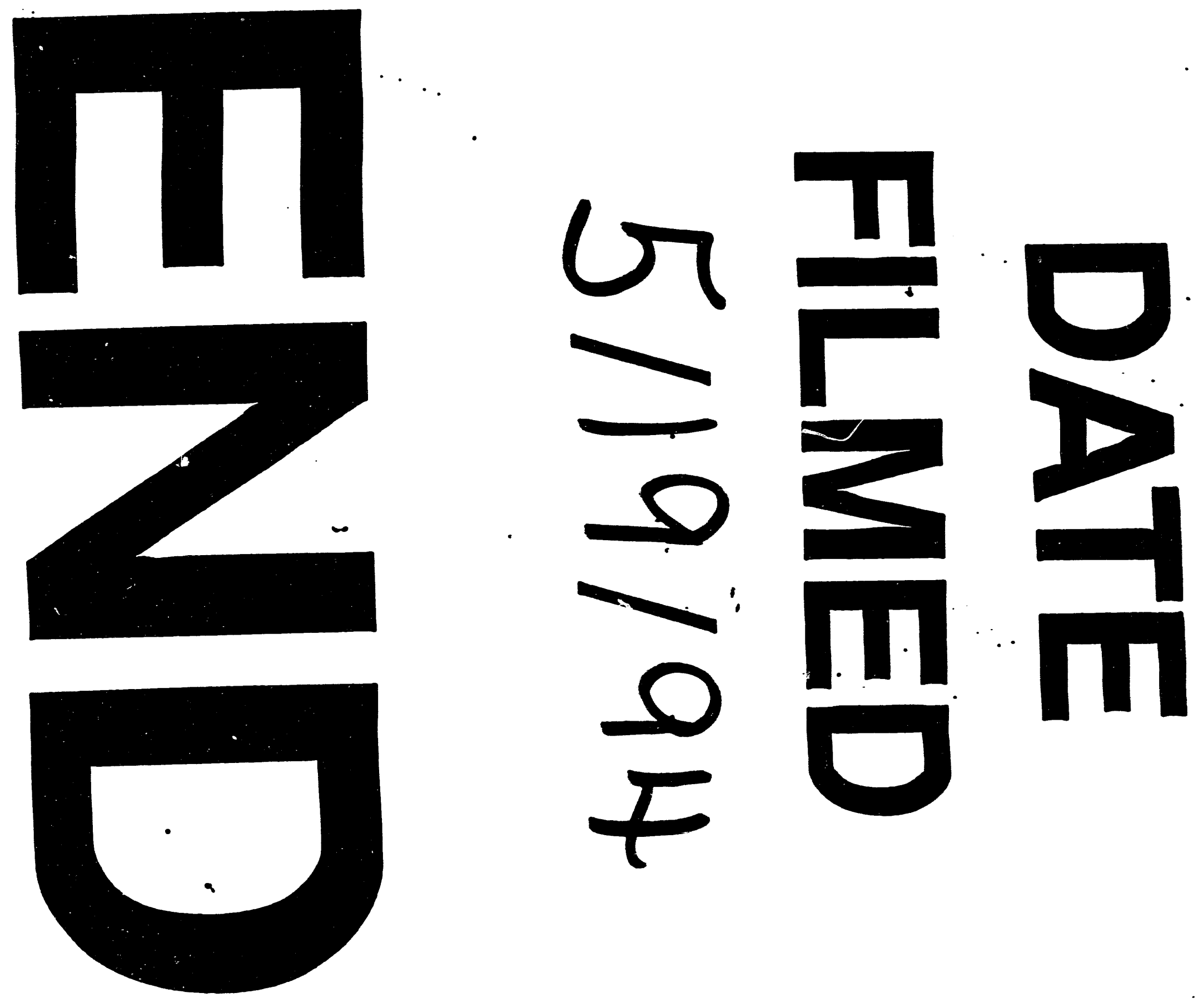
